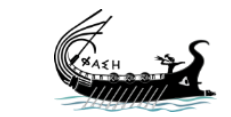

journal.phaselis.org

\title{
Phaselis Antik Kenti Florası III
}

\section{Flora of the Ancient City of Phaselis III}

\section{R. Süleyman GÖKTÜRK}

open 2 access journals

The entire contents of this journal, Phaselis: Journal of Interdisciplinary Mediterranean Studies, is open to users and it is an 'open access' journal. Users are able to read the full texts, to download, to copy, print and distribute without obtaining the permission of the editor and author(s). However, all references to the articles published in the e-journal Phaselis are to indicate through reference the source of the citation from this journal.

Phaselis: Journal of Interdisciplinary Mediterranean Studies is an international peerreviewed journal and the articles which have had their peer reviewing process completed will be published on the web-site (journal.phaselis.org) in the year of the journal's issue (e.g. Volume II: January-December 2016). At the end of December 2016 the year's issue is completed and Volume III: January-December 2017 will begin.

Responsibility for the articles published in this journal remains with the authors.

Citation R. S. Göktürk, "Phaselis Antik Kenti Florası III". Phaselis III (2017) 187-224. http://dx.doi.org/10.18367/Pha.17012

Received Date: 08.06.2017 | Acceptance Date: 01.08.2017 | Online Publication Date: 29.09.2017 


\title{
Phaselis Antik Kenti Florası III
}

\author{
Flora of the Ancient City of Phaselis III
}

\author{
R. Süleyman GÖKTÜRK*
}

Öz: Bu çalışmada 2012 yılında başlayan ve beş yıl süren bu projenin son yılında (2016) tespit edilen bitkiler, bu bitkilere ait genel özellikler ve bazı bitkilerin resimleri verilmiştir. 2016 yılında çalışma alanından toplanan bitkilerin teşhis edilmesiyle 63 familya'ya ait 157 cins ve toplam 195 takson tespit edilmiştir. Bunu yanı sıra beş yıl boyunca (2012-2016) teşhis edilen bitkiler ile ilgili toplam veriler de sonuç ve tartışma bölümünde verilmiştir.

Anahtar sözcükler: Phaselis · Antalya · Bitkiler · Endemik · Pteridophyta · Magnoliophyta · Magnoliopsida · Pinophytina · Liliopsida

Abstract: This study presents the plant species found within the last year (2016) of the project which began in 2012 and is planned to last five years; together with the general features and images of these plants. The plants collected from the research field in 2016 have been identified; 157 genera belonging to 63 families and a total of 195 taxa have been determined. The total data related to the plants determined within five years of the project are given in the conclusion and discussion parts of this study.

Keywords: Phaselis · Antalya · Plants · Endemic · Pteridophyta - Magnoliophyta - Magnoliopsida . Pinophytina · Liliopsida

Giriş

"Phaselis Antik Kenti Florası I" isimli makalenin giriş kısmında ülkemizin, Antalya'nın ve OlimposBeydağları Sahil Milli Parkının bitkiler yönünden zenginliği, çalışmanın materyal ve metodu, bulguların hangi sıra ile verildiğine dair bilgiler ve kullanılan kısaltmalar verilmişti (Göktürk 2015). Bu nedenle tüm bu bilgiler bu makalede de "Phaselis Antik Kenti Florası II" isimli makalede olduğu gibi tekrar edilmemiştir (Göktürk 2016). Bu makalede, birinci ve ikinci makalelerde verilen bitkilere ilave olarak, projenin beşinci ve son yılı olan 2016 yılında toplanan ve teşhisi yapılan 63 familya'ya ait 157 cins ve toplam 195 takson ve bu taksonlara ait kısa açıklayıcı özellikleri verilmiştir. Tespit edilen bu 195 taksonun 120 tanesi tür, 54 tanesi alt tür ve 21 tanesi ise varyete düzeyindedir. Bu 195 taksonun 37 tanesi endemiktir. Bu 37 endemik taksonun 4 tanesi Olimpos-Beydağları Milli Parkı endemiği, 1 tanesi Antalya endemiği ve 32 tanesi de Türkiye endemiğidir. 195 taksonun, 80 tanesi Akdeniz Fitocoğrafik Bölgesi elementi, 6 tanesi Iran-Turan Fitocoğrafik Bölgesi elementi, 4 tanesi Avrupa-Sibirya Fitocoğrafik Bölgesi elementi ve 105 tanesi ise Çok Bölgeli veya Fitocoğrafik Bölgesi bilinmeyendir. Bu dönemde teşhis edilen 195 taksonun 3 tanesi Pteridophyta (Eğreltiler) şubesine, 192 takson ise Magnoliophyta (Tohumlu bitkiler) şubesine aittir. Pinophytina (Açık tohumlular) alt şubesinde 1, Magnoliophytina (Kapalı tohumlular) alt şubesinde ise 191 takson yer almaktadır. Magnoliophytina (Kapalı

*Prof. Dr., Akdeniz Üniversitesi, Fen Fakültesi, Biyoloji Bölümü, Antalya. gokturk@akdeniz.edu.tr 
tohumlular) alt şubesinde yer alan 191 taksonun 168 tanesi Magnoliopsida (Dikotiller) sınıfına, 23 tanesi ise Liliopsida (Monokotiller) sınıfına aittir.

Bulgular

Şube: Pteridophyta (Eğreltiler)

Familya: Polypodiaceae (Benlieğreltigiller)

Polypodium vulgare L. var. vulgare (Benli eğrelti)

Rizomlu çok yıllık bitkiler. Frond üçgenimsi-keskin uçludan yumurtamsıya kadar değişen şekillerde. Yapraklar pinnat parçalı. Spor keseleri gençken yuvarlak. Ülkemizde Trabzon, Artvin, Muğla, Antalya ve Adana illerinde yayılış gösteren bu tür, 200 m’ye kadar güneşli kayalıklar üzerinde yetişir. Sporlar ise nisan-ağustos aylarında olgunlaşır. ÇBFCB. (Fig. 1)

Familya: Pteridiaceae (Baldırıkaragiller)

Pteris vittata L. (Uzun eğrelti)

Kısa rizomlu çok yıllık bitkiler. Yapraksı gövde 20-40 cm boyunda, mızraksı, 1-pinnat parçalı. Yaprakçıklar 10 veya daha parçalı, dar mızraksı. Spor keseleri yaprakçıkların kenarları boyunca kaynaşmış veya geriye kıvrıımış kenarları tarafından çevrilmiş. Ülkemizde Antalya ve Adana illerinde yayılış gösteren bu tür, kaya yarıklarında yetişir ve sporları mayıs-ağustos ayında olgunlaşır. ÇBFCB. (Fig. 2)

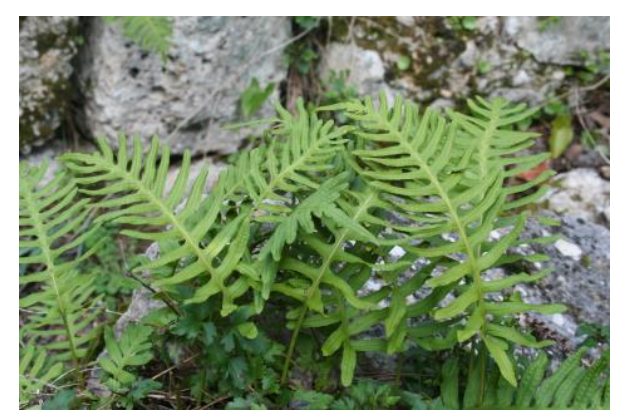

Fig. 1. Polypodium vulgare var. vulgare

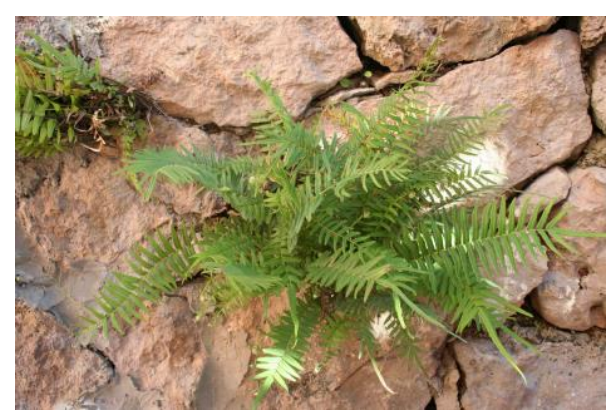

Fig. 2. Pteris vittata

\title{
Cheilanthes pteridioides (Reich.) C. Chr. (Kıvrık eğrelti)
}

4-25 cm boylanabilen bitkiler. Yapraklar kümeli; lamina 2 pinnat parçalı, uç segmentler genişçe yumurtamsı, olgun durumda tamamen çıplak. Sporlar geriye kıvrık olan yaprakçıklar tarafından çevrili. 1000 m’ye kadar olan yüksekliklerdeki kuru kaya yarıklarında yetişen bu türün sporları haziran ayında olgunlaşır. ÇBFCB.

\section{Şube: Magnoliophyta (Tohumlu Bitkiler) \\ Altşube: Pinophytina (Açık Tohumlular) \\ Altsınıf: Pinidae \\ Familya: Pinaceae (Çamgiller) \\ Pinus pinea L. (Fıstık çamı)}

25 m’ye kadar boylanabilen ağaçlar. Gövde genç halde yuvarlak, olgun dönemde ise şemsiye şekilli bir taca sahip. Yapraklar kısa sürgünlerden çift halde çıkar, (6-)8-14 cm boyunda ve açık yeşil renkli. Tomurcuklar reçinesiz. Kozaklar oldukça geniş, kahve renkli, sapsız. Tohumlar kanatsız veya çok kısa kanatlı. Ülkemizde Marmara, Ege ve Akdeniz Bölgeleri'nde yetişen bu türün tohumları çam fıstığı olarak bilinir. ÇBFCB.

\author{
Altşube: Magnoliophytina (Kapalı Tohumlular) \\ Sınıf: Magnoliopsida (Dikotiller) \\ Familya: Amaranthaceae (Horozibiğigiller) \\ Chenopodium ambrosioides $L$. (Sirken)
}


Keskin aromatik bir yıllık veya kısa ömürlü çok yıllık bitkiler. Gövde dik, 1 m’ye kadar boylanır. Yapraklar kısa saplı; aya mızraksıdan eliptike kadar değişen şekillerde. Sepaller serbest ya da yarıya kadar parçalı. Yetişme ortamı olarak 100 m’ye kadar olan plaj kumullarını, yol kenarlarını, duvarları, tarla kenarlarını ve nehir ve kanal yataklarını tercih eden bu tür, haziran-ekim aylarında çiçeklenir. ÇBFCB.

Salsola kali L. (Döngele)

Çıplak veya narin dikenli otsu bitkiler. Yapraklar şeritsi-ipliklsi. Çiçekler hermafrodit, brakte kenarlarında 1-3 tane. Brakteler 2 adet, yumurtamsı-üçgenimsi. Periyant segmentleri 5 adet, tabanda serbest, yumurtamsı. Ülkemizde sadece Antalya'da ülkemiz dışında ise Avrupa, Kuzey Afrika ve Asya'da yetişen bu tür, mayıs-temmuz ayında çiçeklenmekte olup, kıyılarda, kumullarda ve nemli yerlerde yetişir. ÇBFCB.

Familya: Apiaceae (Maydanozgiller)

Anethum graveolens L. (Dereotu)

Dik, çıplak, 60 cm'ye kadar boylanabilen bir yıllık otsu bitkiler. Taban yapraklar üçgenimsi, 3-5 pinnat parçalı; segmentler ipliksi. Sepaller mevcut değil. petaller sarı renkli. Meyveler elipsoid, çıplak. Haziran-temmuz aylarında çiçeklenen bu tür, yetişme ortamı olarak yol kenarlarını ve kültür alanlarına yakın yerleri tercih eder. ÇBFCB.

\section{Smyrnium olusatrum L. (Deli kereviz)}

3-150 cm boyunda, sağlam yapılı, çıplak, iki yıllık bitkiler. Taban yaprakları 2-4 ternat parçalı; uç segmentler eliptik, derin serrat. Şemsiye çiçek durumu 7-17 adet, saplı. Petaller sarı renkli. Meyve hemen hemen yumurtamsı. Ülkemizde Karadeniz, Marmara, Ege ve Akdeniz Bölgeleri'nde, ülkemiz dışında ise güney ve batı Avrupa'da ve Arnavutluk'ta yayılış gösteren bu tür, mart-mayıs aylarında çiçeklenir. Yetişme ortamı olarak ise deniz seviyesinden 980 m'ye kadar olan yüksekliklerdeki yol kenarlarını, nemli yerleri ve deniz kenarındaki kayalıkları tercih eder. Akd. El. (Fig. 3)

Torilis arvensis (Huds.) Link subsp. elongata (Hoffmanns. \& Link) Cannon (Bodonaz)

100 cm'ye kadar boylanabilen dik gövdeli bir yıllık otsu bitkiler.

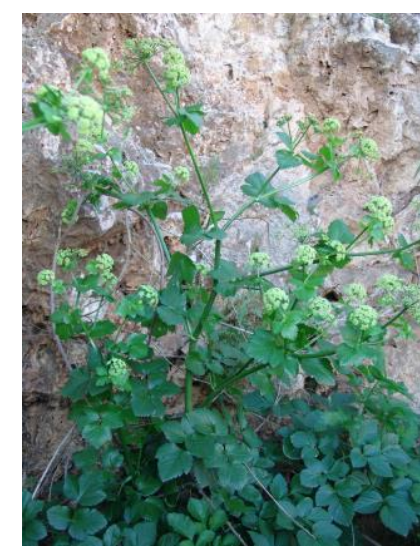

Fig. 3. Smyrnium olusatrum Yapraklar 1-2 pinnat veya üst yapraklar 3 yaprakçıklı. Petaller beyaz veya pembe renkli. Meyveler yumurtamsı, dikenli. Bu alt tür, yetişme ortamı olarak deniz seviyesinden 800 m'ye kadar olan yüksekliklerdeki makilikleri, çalılıkları ve yamaçları tercih eder. Çiçeklenme zamanı ise nisan-haziran aylarıdır. Akd. El.

\section{Familya: Asteraceae (Papatyagiller)}

\section{Anthemis chia L. (Beyaz papatya) (Garga çiçeği)}

35 cm'ye kadar boylanabilen, dik veya eğik tırmanışlı bir yıllık otsu bitkiler. Yapraklar 2pinnatisekt parçalı; loplar ters mıraksı. Dilsi çiçekler beyaz renkli, tüpsü çiçekler ise sarı renkli. Aken meyveler ters kozalaksı. Bu papatya türü mart-haziran aylarında çiçeklenir. Yetişme ortamı olarak deniz seviyesinden 300 m'ye kadar olan yüksekliklerdeki yol kenarlarını ve deniz kenarındaki kalkerli toprakları tercih eder. Akd. El.

\section{Anthemis cretica L. subsp. anatolica (Boiss.) Grierson (Horoz papatyası)}

Kısa rizomlu çok yıllık bitkiler. Gövde kalkık uçlu veya eğik tırmanışlı, 10-20(-30) boyunda. 
Yapraklar pinnatisekt parçalı. Dilsi çiçekler beyaz renkli, tüpsü çiçekler sarı renkli. Aken meyveler memecikli. Mayıs-temmuz aylarında çiçeklenen bu alt tür, yetişme ortamı olarak, 280-2285 m'ler arasındaki stebi, yol kenarlarını ve kireç tepelerini tercih eder. ÇBFCB.

\section{Carduus pycnocephalus L. subsp. albidus (M. Bieb.) Kazmi (Eşek soymacı)}

Bir yıllık otlar. Gövde 5-75 cm boyunda, basit veya dallı. Yapraklar pinnat parçalı. Kapitula sapsız, 2-5’li. Korolla mor-pembe renkli. Meyve aken. Ülkemiz dışında Yunanistan, Kırım, Mısır ve Güney batı Asya'da yayılış gösteren bu alt tür, nisan-haziran aylarında çiçeklenir. Yetişme ortamı olarak deniz seviyesinden 1450 m’ler arasındaki kayalık yerler, tarlalar, nemli yerler ve kızılçam ormanlarını tercih eder. ÇBFCB.

\section{Centaurea cariensis Boiss. subsp. maculiceps (O. Schwarz) Wagenitz (Gül acımık)}

Tabanda odunlu çok yıllık bitkiler. Yapraklar beyaz-keçemsi tüylü, pinnat veya lirat parçalı. Çiçekler gül veya mor renkli. Meyve aken. Bu alt tür haziran ve temmuz ayında çiçeklenmekte olup, yetişme ortamı olarak 900-2300 m’ler arasındaki kayalık yamaçlar ve ormanlık alanları tercih eder. ÇBFCB.

\section{Centaurea urvillei DC. subsp. urvillei (Alakötürüm)}

Kısa yaşamlı çok yıllık otsu bitkiler. Gövde basit veya tabanda dallı. Yapraklar seyrek tüylü, lirat parçalı. Çiçekler gül-mor renkli veya beyaz renkli. Aken meyve 4$6 \mathrm{~mm}$ boyunda. Bu alt tür yetişme ortamı olarak deniz seviyesinden 2000 m'ye kadar olan kayalık yamaçları, çam ormanı açıklıklarını ve makilik alanları tercih eder. Haziran-temmuz aylarında çiçeklenir. D. Akd. El. (Fig. 4)

\section{Cirsium vulgare (Savi) Ten. (Yaygın kangal)}

50-150 cm boyunda iki yıllık otsu bitkiler. Gövde dallı. Gövde yaprakları dikdörtgenimsi, pinnatisekt parçalı. Çiçekler pembe-mor'dan mor renge kadar değişir. Aken meyve 3.5-4.5 mm boyunda. Bu bitki, yetişme ortamı olarak deniz seviyesinden başlayarak 2000 m'ye kadar olan yüksekliklerdeki, çam ormanı açıklıklarını, yol kenarlarını ve yamaçlarını tercih eder. Temmuzekim aylarında çiçeklenir. ÇBFCB. (Fig. 5)

\section{Conyza canadensis (L.) Cronquist (Selviotu)}

100 cm'ye kadar boylanabilen seyrek tüylü bir yıllık

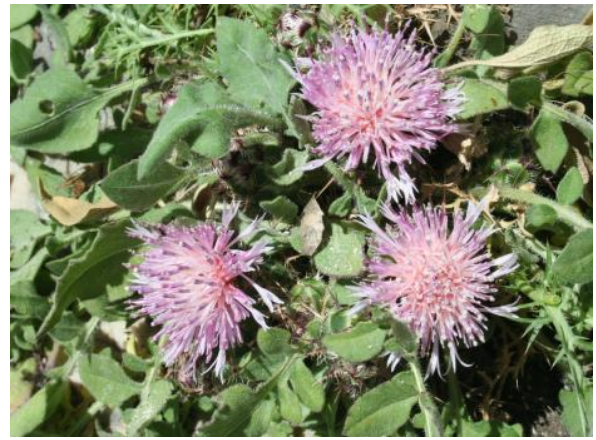

Fig. 4. Centaurea urvillei DC. subsp. urvillei

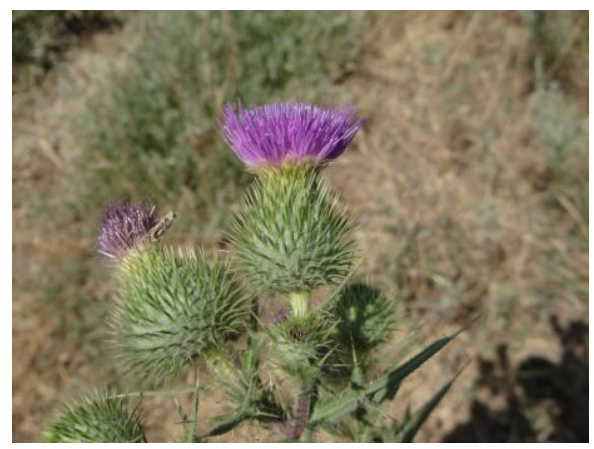

Fig. 5. Cirsium vulgare otlar. Yapraklar darca ters mırraksı. Dişi çiçekler beyaz veya morumsu. Aken meyve seyrek tüylü. Temmuz-aralık aylarında çiçeklenen bu bitki, yetişme ortamı olarak deniz seviyesinden başlayarak 1300 m'ye kadar olan yüksekliklerdeki nemli yerleri, deniz kıyısını ve nemli yerleri tercih eder. ÇBFCB.

\section{Crepis foetida L. subsp. foetida (Kohum)}

75 cm'ye kadar boylanabilen bir yıllık bitkiler. Alt yapraklar eliptik-ters yumurtamsı. Çiçekler sarı renkli. Meyve aken. Bilim dünyasına ilk kez Fransa'dan tanıtılan bu bitki, mayıs-ekim aylarında çiçeklenir. Bu alt tür, yetişme ortamı olarak deniz seviyesinden 1300 m'ye kadar olan makilikleri, kayalıkları, kum tepelerini ve çam ormanlarını tercih eder. ÇBFCB.

Cyanus triumfetii (All.) Dostal ex A. Löve \& D. Löve subsp. triumfetii (Deli Kapele) 
60 cm'ye kadar boylanabilen çok yılık otsu bitkiler. Yapraklar keçemsi tüylü bazen çıplak, genişçe mızraksı veya şeritsi. Kenardaki çiçekler mavi, menekşe veya menekşe-mor, merkezdekiler ise menekşe-mor renkli. Aken meyve 4-5 mm boyunda. Oldukça geniş bir yayılış alanına sahip olan bu tür 3 alt gruba ayrılmaktadır. Bitki mayıs-ağustos aylarında çiçeklenir. ÇBFCB.

\section{Doronicum orientale Hoffm. (Kaplan otu)}

60 cm'ye kadar boylanabilen, seyrek tüylü çok yıllık otlar. Alt yapraklar yumurtamsı-eliptik, saplı. Gövde yaprakları sapsız, gövdeyi sarıcı. Dilsi ve tüpsü çiçekler sarı renkli. Aken meyve dikdörtgenimsi-topaçsı. Bilim dünyasına Kafkasya'dan tanıtılan bu tür, mart-temmuz aylarında çiçeklenir. Bu kaplan otu yetişme ortamı olarak 50-1900 m’ler arasındaki gölgelik orman altlarını ve çalılık yerleri tercih eder. ÇBFCB. (Fig. 6)

\section{Echinops ritro L. (Topuz)}

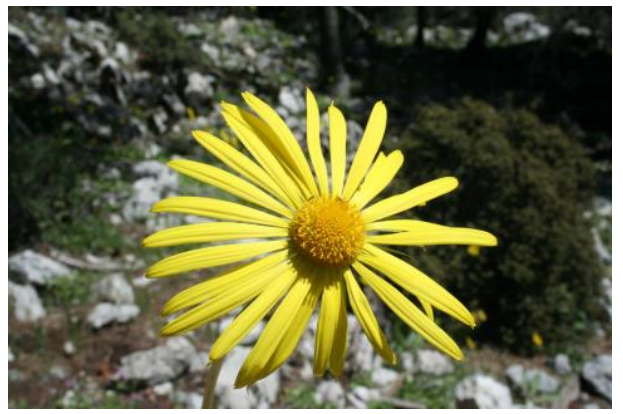

Fig. 6. Doronicum orientale

Narin yapılı çok dallı bitkiler. Yapraklar pinnatisekt parçalı, dar üçgenimsi veya dikdörtgenimsi eliptik. Kafalar 3-4.5 cm çapında. Çiçekler açık maviden koyu mavi'ye kadar değişir. Aken meyve yaklaşık $6 \mathrm{~mm}$ boyunda. Temmuz-ekim aylarında çiçeklenen bu tür, yetişme ortamı olarak stepteki kayalık yamaçları, nehir yataklarını, tarlaları tercih eder. ÇBFCB.

\section{Geropogon hybridus (L.) Schultz (Melez yemlik)}

Narin yapılı, çıplak, bir yıllık otsu bitkiler. Gövde 45 cm'ye kadar boylanır. Yapraklar şeritsi. Fillariler 8 tane, çiçeklerden uzun. Çiçekler leylaktan mor'a kadar değişen renklerde. Aken meyve düz veya pürüzlü. Ülkemizde oldukça geniş bir yayılış alanına sahip olan bu tür yetişme ortamı olarak deniz seviyesinden başlayarak 1100 m'ye kadar olan yüksekliklerdeki kayalık yamaçları ve çalılıkları tercih eder. Bitkinin çiçeklenme zamanı ise nisan-temmuz aylarıdır. Akd. El. (Fig. 7)

\section{Glebionis coronaria (L.) Spach (Alagömeç)}

Çıplak, $15-70 \mathrm{~cm}$ boyunda bir yıllık otsu bitkiler. Yapraklar ters yumurtamsı, 2-3 piannatisekt parçalı. Dilsi çiçekler sülfür sarısı, krem veya beyaz renkli, 1215 tane. Tüpsü çiçekler sarı renkli. Aken meyve dikdörtgenimsi-topaçsı. Ülkemiz dışında Suriye çölünde ve kuzey-batı İran'da da yetişen bu tür, nisan-haziran aylarında çiçeklenir. Yetişme ortamı olarak ise deniz seviyesinden 500 m'ye kadar olan nehir yataklarını, yol kenarlarını ve deniz kenarındaki tarlaları tercih

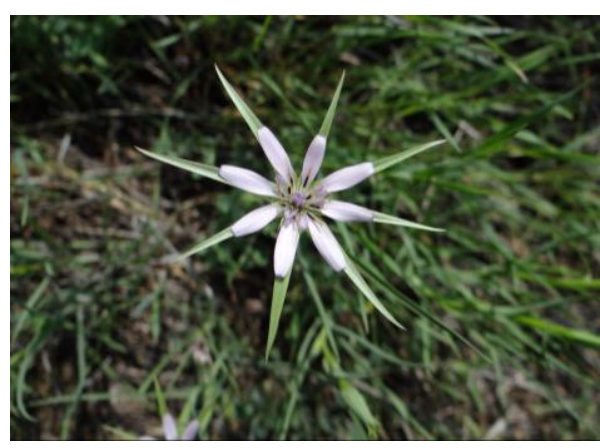

Fig. 7. Geropogon hybridus

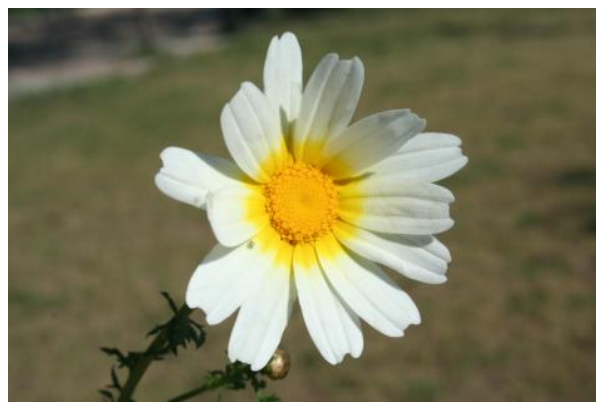

Fig. 8. Glebionis coronaria eder. ÇBFCB. (Fig. 8)

\section{Hyoseris scabra L. (Kaba semirten)}

Bir yıllık bitkiler. Yapraklar darca dikdörtgenimsi, 3-8 cm boyunda. Çiçek kümesi sapı yatık gövdeli, genellikle kapitulumun alt kısmında kalınlaşmış. Çiçekler sarı renkli. Aken meyve çıplak veya tüylü, 7-8 mm boyunda. Bilim dünyasına ilk kez Sicilya adasından toplanarak tanıtılan bu tür, mart-temmuz aylarında çiçeklenir. Yetişme ortamı olarak ise deniz kenarlarındaki kayalık yerleri 
tercih eder. Akd. El.

\section{Inula graveolens (L.) Desf. (Deli sarıot)}

Çok dallı, 1 m’ye kadar boylanabilen bir yıllık bitkiler. Yapraklar şeritsi-mızraksı. Tüm çiçekler sarı renkli. Aken meyve $2 \mathrm{~mm}$ boyunda, uç kısımda tüylü. Ağustos-ekim aylarında çiçeklenen bu tür, yetişme ortamı olarak deniz seviyesinden başlayarak 800 m'ye kadar olan yüksekliklerdeki dere kenarlarını, tarlaları ve kumlu toprakları tercih eder. Akd. El.

\section{Jurinea consanguinea DC. (Geyik göbeği)}

Çok yıllık otsu bitkiler. Gövde 20-35 cm boyunda, seyrek örümcek ağsı tüylü. Alt yapraklar tam kenarlı veya pinnatisekt parçalı; parçalar şeritsi-mızraksı. Çiçekler leylak, mor veya koyu kırmızı renkli. Meyve aken. Ülkemizin hemen hemen tüm bölgelerinde yayılış gösteren bu tür, yetişme ortamı olarak deniz seviyesinden başlayarak 800 m'ye kadar olan yüksekliklerdeki stebi, kayalıkları, kültür alanlarını ve ormanlık alanları tercih eder. ÇBFCB. (Fig. 9)

\section{Lactuca serriola L. (Eşek helvası)}

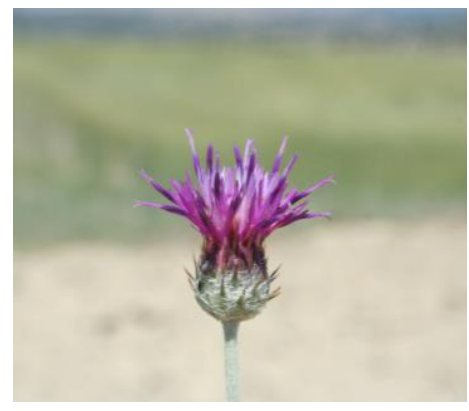

Fig. 9. Jurinea consanguinea

150 cm'ye kadar boylanabilen dik, iki yıllık otsu bitkiler. Gövdeler tüysüz, alt kısımda dikensi tüylü. Yapraklar pinnatisekt parçalı. Çiçekler soluk sarı veya sarı renkli. Aken meyve soluk kahverengi. Bu tür ülkemizin tüm bölgelerinde yayılış göstermekte olup, temmuz-eylül aylarında çiçek açmaktadır. Yetişme ortamı olarak ise deniz seviyesinden başlayarak 1750 m'ye kadar olan yüksekliklerdeki kayalık yamaçları, tarla kenarlarını ve kültür alanlarını tercih eder. ÇBFCB.

\section{Matricaria chamomilla L. var. chamomilla (Alman papatyası)}

10-45 cm boyunda, çıplak bir yıllık otsu bitkiler. Gövde dik veya eğik tırmanışlı. Yapraklar 2-3 pinnatisekt. Dilsi çiçekler beyaz renkli.. Tüpsü çiçekler sarı renkli. Aken meyve kahve renkli. Ülkemizde Antalya, İstanbul, Muğla ve Aydın illerinde, ülkemiz dışında ise Filistin, Irak ve kuzeybatı Hindistan'da yayılış gösteren bu bitki, yetişme ortamı olarak ise deniz seviyesinden başlayarak 900 m'ye kadar olan yüksekliklerdeki yol kenarlarını, nemli ve kültür alanlarını tercih eder. ÇBFCB.

\section{Onopordum sibthorpianum Boiss. \& Heldr. (Uslu kenker)}

$130 \mathrm{~cm}$ 'ye kadar boylanabilen iki yıllık bitkiler. Gövde dik, üst kısımda dallı. Alt yapraklar dikörtgenimsi-mızraksı. Kapitula örümcek ağsı tüylü. Çiçekler leylak-mor. Aken meyve tetragonal. Bu tür ülkemiz dışında, Yunanistan, Girit ve Malta adasında yetişmektedir. Haziran ve temmuz aylarında çiçeklenen bu bitki, yetişme ortamı olarak 1000-1800 m'ler arasındaki orman açıklıklarını, stebi ve takip eden tarlaları tercih eder. D. Akd. El.

Ptilostemon afer (Jacq.) Greuter subsp. eburneus Greuter (Has bozlanotu) (Türkiye endemiği)

$1 \mathrm{~m}$ veya daha fazla boylanabilen iki yıllık otsu bitkiler. Gövde bazen alt kısımda dallı. Yapraklar mızraksı, oyuklu veya pinnatifid parçalı. Çiçekler beyaz renkli. Aken meyve ters yumurtamsı. Ülkemize özgü

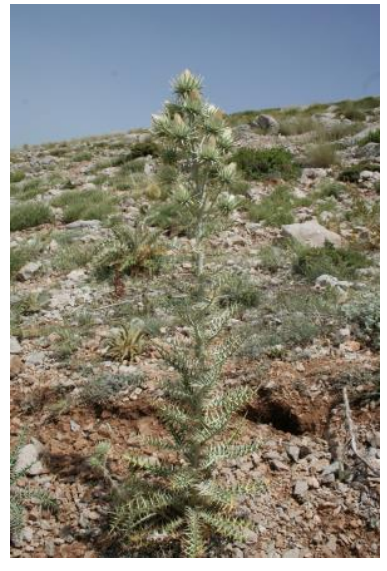

Fig. 10. Ptilostemon afer subsp. eburneus olan bu alt tür, haziran-ağustos aylarında çiçeklenir. Bu endemik alt tür yetişme ortamı olarak 900-2450 m’ler arasındaki, çıplak kayalıkları, taşı ve killi toprakları ve kuru nehir yataklarını 
tercih eder. ÇBFCB. (Fig. 10)

\section{Rhagadiolus stellatus (L.) Gaertn. (Çatlakçanak)}

Zayıf sert kıllı tüylü, 12-60 cm boyunda bir yıllık otsu bitkiler. Yapraklar çoğunlukla tabanda, kenarları dişli. Fillariler tüylü veya küçük setoz tüylü. Dilsi çiçekler sarı renkli. Dış akenler yıldızsı yayılışlı ve tüylü. İç akenler kıvrılmış. Mart-mayıs aylarında çiçeklenen bu tür, 1500 m’ye kadar olan yüksekliklerdeki kireç taşlı kayalıkları, friganayı ve nemli yerleri tercih eder. Akd. El.

\section{Senecio vulgaris L. (Taşakcılotu otu)}

50 cm'ye kadar boylanabilen bir yıllık nadiren iki yıllık otsu bitkiler. Alt yapraklar saplı, dikdörtgenimsiden ters yumurtamsıya kadar değişen şekillerde, pinnatifid loplu. Dilsi çiçekler yok, tüpsü çiçekler sarı renkli. Aken meyve 1.5-2.5 mm boyunda. Ülkemizde geniş bir yayılış alanına sahip olan bu bitki mart-ağustos aylarında çiçeklenir. Yetişme ortamı olarak deniz seviyesinden 700 m'ye kadar olan yüksekliklerdeki kumlu ve nemli alanları, tarlaları ve makiyi tercih eder. ÇBFCB.

\section{Sonchus oleraceus L. (Kuzugevreği)}

Bir veya iki yıllık otsu bitkiler. Gövde 10-150 cm boyunda, üst kısımda salgılı tüylü. Alt yapraklar yumurtamsıdan ters yumurtamsıya kadar değişen şekillerde. Çiçekler soluk sarı renkli. Aken meyve 2-3 mm boyunda ve basık. Çiçeklenme zamanı mart-mayıs ayları olan bu tür, yetişme ortamı olarak deniz seviyesinden 1300 m'ye kadar olan yüksekliklerdeki tarlaları ve nemli yerleri tercih eder. ÇBFCB. (Fig. 11)

\section{Taraxacum buttleri Soest (Karahindiba)}

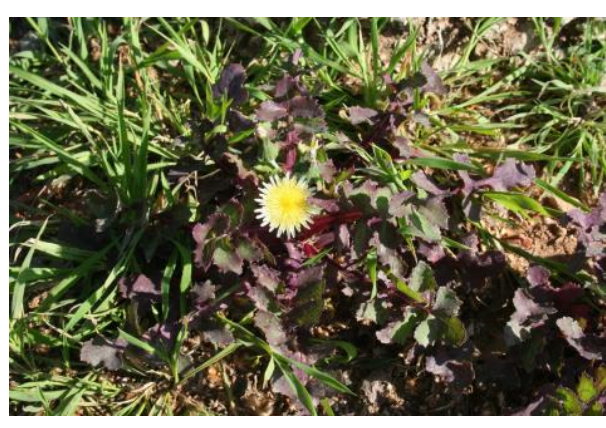

Fig. 11. Sonchus oleraceus

Küçük bitkiler. Yapraklar birkaç tane. Çiçekler sarı renkli. Aken meyve koyu-kahverengi-kırmızı renkli, 4-4.5 mm boyunda. Illk kez Antalya-Elmalı'dan toplanarak bilim dünyasına tanıtılan bu karahindiba türü, nisan-haziran aylarında çiçeklenir. Yetişme ortamı olarak ise 150-2300 m’ler arasındaki yol kenarlarını, tarlaları ve kayalık yerleri tercih eder. ÇBFCB.

\section{Tragopogon olympicus Boiss. (Ulu yemlik) (Türkiye endemiği)}

5-15 cm boyunda çok yıllık otsu bitkiler. Yapraklar mızraksı, nadiren yumurtamsı. Fillariler 8 adet, çiçeklerden kısa. Çiçekler sarı renkli. Aken meyve 16-20 mm boyunda. Ülkemize özgü olan bu tür, Bursa, Isparta, İzmir, Muğla ve Antalya illerinde yayılış göstermektedir. Kayalık yerleri ve kuru otlakları yetişme ortamı olarak seçen bu tür, 15002300 m’ler arasındaki yüksekliklerde yetişir. Akd. El.

\section{Xanthium spinosum L. (PItrak)}

100 cm'ye kadar boylanabilen çok dallı bir yıllık otsu bitkiler. Yapraklar sapsız veya kısa saplı, üst kısmı koyu yeşil, alt kısmı ise gri keçemsi tüylü. Meyveli involukrum 10-15 cm boyunda, dikenler uçta çengelli. illk kez Portekiz'den toplanarak bilim dünyasına tanıtılan bu tür, ağustos-ekim aylarında çiçeklenir. Yetişme ortamı

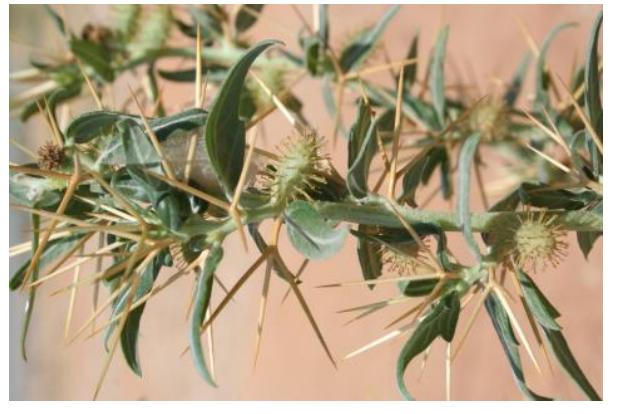

Fig. 12. Xanthium spinosum 
olarak ise, $10-1750$ m'ler arasındaki kuru yamaçları ve nemli alanları tercih eder. ÇBFCB. (Fig. 12)

\section{Familya: Berberidaceae (Karamukgiller)}

\section{Leontice leontopetalum L. (Kıkbaş)}

Yumrulu, dik gövdeli, 10-80 cm boyunda. Yapraklar etli, çok parçalı, segmentler ters yumurtamsıdan yarı dairesele kadar değişir. Çiçek durumu uçta, çok çiçekli, uzun saplı. Petaller sarı renkli. Meyve kuru ve şişmiş. Yetişme ortamı olarak deniz seviyesinden başlayarak 1000 m’ye kadar olan yüksekliklerdeki nemli kültür alanlarında yetişen bu tür, şubat-mayıs ayında çiçeklenir. ÇBFCB. (Fig. 13)

\section{Familya: Boraginaceae (Hodangiller)}

\section{Alkanna tinctoria (L.) Tausch subsp. subleiocarpa} (Hub.-Mor.) Hub.-Mor. (Uşak havacivası)

40 cm'ye kadar boylanabilen çok yıllık otlar. Taban yaprakları şeritsiden dikdörtgenimsi-mızraksıya kadar değişen şekillerde. Korolla mavi renkli. Meyve fındıksı.

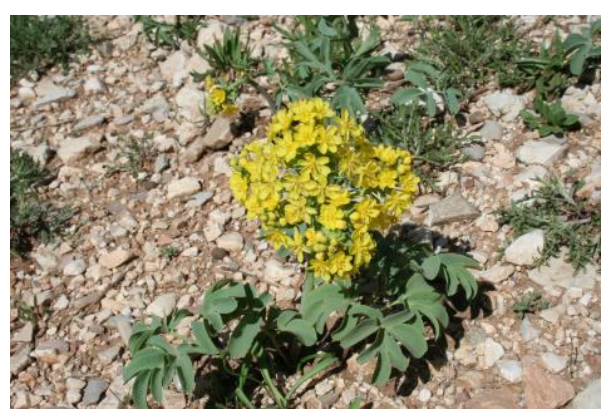

Fig. 13. Leontice leontopetalum

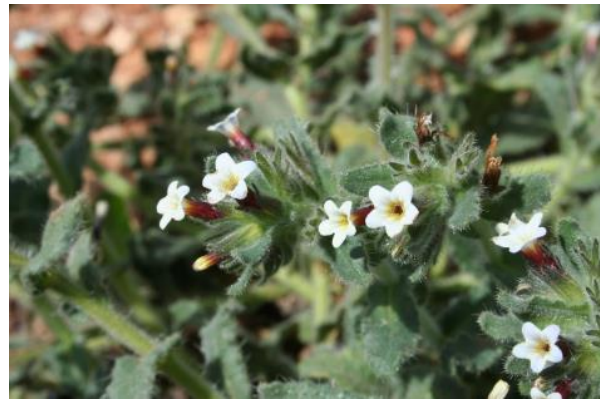

Fig. 14. Alkanna tubulosa Yetişme ortamı olarak deniz seviyesinden başlayarak 600 m'ye kadar olan yüksekliklerdeki kum tepelerini, çam ormanlarını ve stebi tercih eden bu alt tür, nisan-mayıs aylarında çiçeklenir. D. Akd. El.

\section{Alkanna tubulosa Boiss. (Ege havacivası)}

15-30 cm boyunda, salgılı tüylü veya sert kıllı tüylü. Taban yaprakları dikdörtgenimsi-kamamsıdan şeritsi-mızraksıya kadar değişen şekillerde. Korolla dudakları beyaz veya sarımsı, tüp kahve renkliden menekşeye kadar değişen şekillerde. Fındıksı meyveler yarı dairesel. Bu tür, nisanhaziran aylarında çiçeklenmekte olup, yetişme ortamı olarak kızılçam ormanlarını, kireç taşlı kayaIıkları, stebi ve friganayı tercih eder. D. Akd. El. (Fig. 14)

\section{Anchusa officinalis L. (Ballağan)}

Çoğunlukla tabanda dallı, sert dikenli tüylü. Gövde dik, 30-60 (-170) cm boyunda. Yapraklar şeritsiden şeritsi-ters mızraksıya kadar değişir. Brakteler şeritsi. Korolla koyu mavi renkli. Meyve yumurtamsı. Nisan-temmuz aylarında çiçeklenen bu tür, 200-1600 m’ler arasındaki kızılçam ormanlarını ve tarlaları tercih eder. Avr.-Sib. El.

Buglossoides arvensis (L.) I. M. Johnst. subsp. sibthorpiana (Griseb.) R. Fern. (Tarla taşkeseni)

Gövde basit veya dallı (2-)8-30 cm boyunda, dik veya eğik tırmanışlı. Yapraklar şeritsi, mızraksı, darca eliptik veya ters mızraksı. Korolla beyaz, soluk veya koyu mavi veya morumsu renkli, huni biçimli. Meyve fındıksı. Ülkemizin hemen hemen tüm bölgelerinde yetişen bu alt tür, şubathaziran aylarında çiçeklenir. Yetişme ortamı olarak deniz seviyesinden 2500 m'ye kadar olan yüksekliklerdeki kireç taşlı kayalık yamaçları, tarla kenarlarını, mısır tarlalarını, kayalık yamaçları ve stebi tercih eder. ÇBFCB.

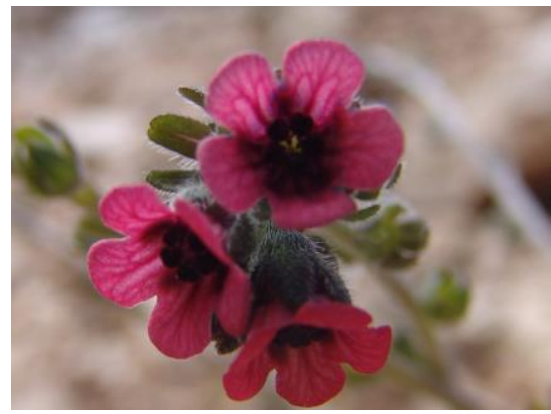

Fig. 15. Cynoglossum montanum 


\section{Cynoglossum montanum L. (Dağ köpekdili)}

Iki yıllık, yumuşak veya basık tüylü, 50 cm'ye kadar boylanabilen bitkiler. Yapraklar şeritsidikdörtgenimsiden şeritsi-mızraksıya kadar değişen şekillerde. Korolla koyu kiremit kırmızısı veya koyu pembe renkli, nadiren mavi renkli. Meyve fındıksı. Nisan-ağustos aylarında çiçeklenen bu tür, 360-2200 m'ler arasındaki meşe ve ardıç çalııklarını, stebi, kayalık yamaçları ve çayırlıkları tercih eder. Avr.-Sib. El. (Fig. 15)

\section{Echium parviflorum Moench (Kızıl engerek otu)}

Yatık gövdeli veya eğik tırmanışlı bir veya iki yıllık bitkiler. Gövdeler çok sayıda, 10-35 cm boyunda, sert-kıllı tüylü. Yapraklar eliptikten kaşıksıya kadar değişen şekillerde. Korolla gök mavisi veya beyaz. Fındıksı meyve genişçe piramidal. Ülkemizde Ege ve Akdeniz Bölgelerinde yayılış gösteren bu tür, mart-nisan aylarında çiçeklenir. Yetişme ortamı olarak deniz seviyesinden 50 m’ye kadar olan yüksekliklerdeki kayalık kireç taşlı yamaçları ve çimenlik alanları tercih eder. Akd. El.

\section{Myosotis alpestris F. W. Schmidt subsp. alpestris (Boncuk otu)}

Çok yıllık ve kısa rizomlu bitkiler. Gövde $5-35 \mathrm{~cm}$ boyunda. Taban yaprakları yumurtamsıdan eliptiğe kadar değişen şekillerde. Korolla mavi renkli; dudakları tekerlek şeklinde. Fındıksı meyve genişçe yumurtamsı-eliptik. Ülkemizde oldukça geniş bir yayılış alanına sahip boncuk otu nisanağustos aylarında çiçeklenir. Yetişme ortamı olarak (410-)1000-3500 m’ler arasındaki yüksekliklerdeki kayalıkları, yamaçları ve çayırlık alanları tercih eder. ÇBFCB.

Omphalodes luciliae Boiss. subsp. Iuciliae (Süreyre) (Türkiye endemiği)

Çok yıllık, 5-25 cm boyunda, eğik tırmanışlı, sürünücü veya tırmanıcı bitkiler. Yapraklar yumurtamsıdan dikdörtgenimsiye kadar değişen şekillerde. Korolla soluk mavi (nadiren beyaz) renkli. Fındıksı meyve $2.5 \mathrm{~mm}$ boyunda. Ülkemize özgü olan bu alt tür, Denizli, Aydın, Antalya ve Isparta illerinde yayılış göstermektedir. Haziran-eylül aylarında çiçeklenen bu bitki yetişme ortamı olarak 1200-3350 m’ler arasındaki yüksekliklerdeki gölgeli kaya yarıklarını ve dikey sarp kayalıkları tercih eder. D. Akd. (Dağ) El. (Fig. 16)

\section{Onosma mitis Boiss. \& Heldr. (Çam şincarı)}

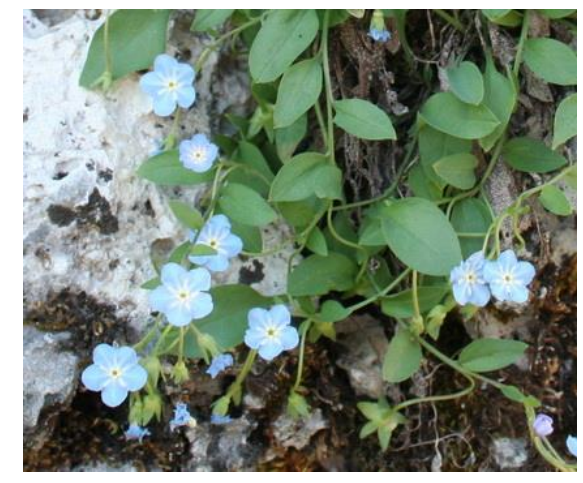

Fig. 16. Omphalodes /uciliae subsp. Iuciliae

10-20 cm boyunda, yoğun keçemsi tüylü, çok yıllık bitkiler. Yapraklar şeritsi-eliptik. Korolla ilk önce sarı renkli, daha sonra pembe son olarak ise mavi renkli. Fındıksı meyve yumurtamsı. Ülkemizde sadece Antalya ilinde, ülkemiz dışında ise sadece Kıbrıs'ta yetişmektedir. Yetişme ortamı olarak deniz seviyesinden başlayarak 1900 m'ye kadar olan yüksekliklerdeki serpantin kayalıkları ve kızılçam ormanlarını tercih eder. D. Akd. El.

Paracaryum lithospermifolium (Lam.) Grande subsp. cariense (Boiss.) R. Mill. var. cariense (Muğla çarşağı)

Kalkık uçlu veya eğik tırmanışlı çok yıllık otsu bitkiler. Taban yaprakları ters yumurtamsı, basık ipeksi-uzun yumuşak tüylü. Korolla kırmızı-menekşe-mor renkli. Fındıksı meyve yarı dairesel. Nisan-ağustos aylarında çiçeklenen bu bitki yetişme ortamı olarak 790-3050 m'ler arasındaki kireç taşlı kayalık yamaçları ve kaya yarıklarını tercih eder. D. Akd. (Dağ) El. 
Symphytum brachycalyx Boiss. (Kabakafes otu)

20-60 cm boyunda çok yıllık otsu bitkiler. Yapraklar şeritsi-dikdörtgenimsi veya yumurtamsıdan dar yumurtamsıya kadar değişen şekillerde veya şeritsimızraksı. Korolla beyaz renkli. Fındıksı meyve yumurtamsı, 2.5-3 mm boyunda. Bu tür, ülkemizde Akdeniz Bölgesi ile Kayseri'de, ülkemiz dışında ise batı Suriye'de yayılış gösterir. Yetişme ortamı olarak ise 800-2200 m’ler arasındaki göknar ve sedir ormanlarını, gölgeli yerleri tercih eden bu bitki nisan-temmuz aylarında çiçeklenir. D. Akd. El. (Fig. 17)

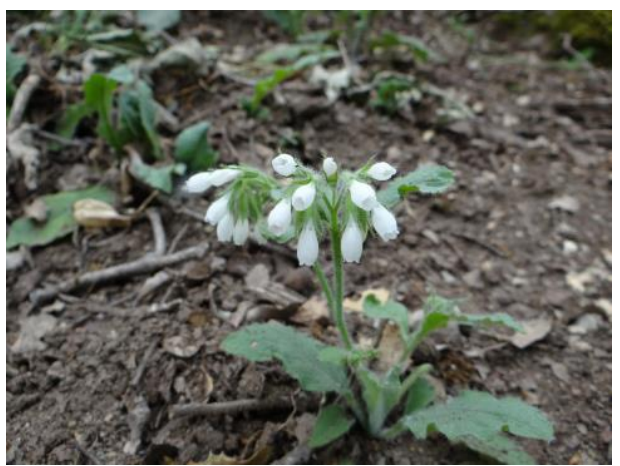

Fig. 17. Symphytum brachycalyx Familya: Brassicaceae (Turpgiller)

Arabis alpina L. subsp. brevifolia (DC.) Cullen (Düz kazteresi)

Çok yıllık otsu bitkiler. Gövde dik veya eğik tırmanışlı. Rozet yapraklar ters yumurtamsı; gövde yaprakları dikdörtgenimsi, tabanda kulakçıklı, yoğun veya seyrek yıldızsı tüylü. Petaller beyaz renkli. Silikuva meyve basık. Mart-ağustos aylarında çiçeklenen bu bitki yetişme ortamı olarak 350-2900 m’ler arasındaki, kayalıkları, uçurumları ve yamaçları tercih eder. D. Akd. (Dağ) El.

\section{Eruca vesicaria Miller (Roka)}

50 cm'ye kadar boylanabilen dik gövdeli bir yıllık otsu bitkiler. Yapraklar pinnatifid parçalı. Petaller sarı renkli, kahve veya menekşe renkli damarlı. Silikula meyve 17-38 mm boyunda. Mart-mayıs aylarında çiçeklenen bu tür, yetişme ortamı olarak deniz seviyesinden başlayarak 200 m’ye kadar olan yüksekliklerdeki tarlaları ve nemli yerleri tercih eder. ÇBFCB.

Matthiola longipetala (Vent.) DC. subsp. pumilio (Sibth. \& Smith) P. W. Ball (Cüce şebboy) (Antalya endemiği)

$50 \mathrm{~cm}$ 'ye kadar boylanabilen bir yıllık otsu bitkiler. Alt yapraklar basit veya parçalı. Petaller beyazımsı veya sarımsıdan mora kadar değişen şekillerde. Silikuva meyve 3-6 cm boyuna kadar çıkar. Stigma 2 uzun keskin sivri uçlu boynuzlu. Ülkemize özgü olan bu alt tür, sadece Antalya ilinde yayılış göstermektedir. Yetişme ortamı olarak ise deniz kenarlarındaki kum temellerini tercih eder. Çiçeklenme zamanı ise mayıs ayıdır. ÇBFCB.

Matthiola montana Boiss. (Akdağ şebboyu) (Türkiye endemiği)

Sağlam yapılı, meyve'de $17 \mathrm{~cm}$ 'ye kadar boylanabilen çok yıllık otsu bitkiler. Alt yapraklar dar ters mızraksı, beyaz keçesi tüylü veya yarı çıplak. Petaller kahverenginden sarımsıya kadar değişen renklerde. Silikuva meyve 13 cm'ye kadar boylanabilir. Ülkemize özgü olan bu tür, Antalya, Isparta, Malatya ve Bursa illerinde yayılış göstermekte olup, temmuz ve ağustos aylarında çiçeklenir. Yetişme ortamı olarak ise 1500 m’ye kadar olan yüksekliklerdeki kayalık yamaçları

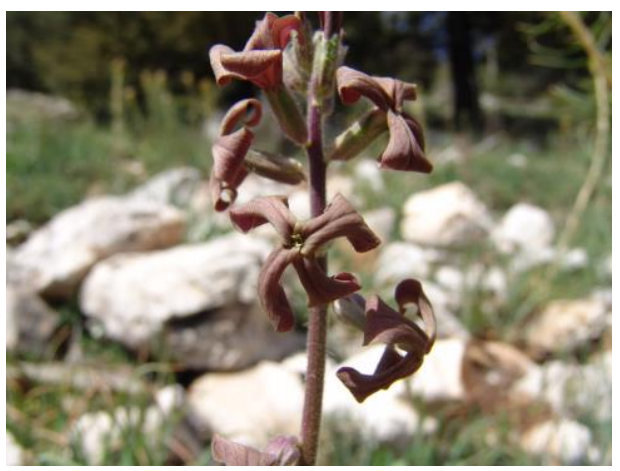

Fig. 18. Matthiola montana



Fig. 19. Ricotia davisiana 
tercih eder. ÇBFCB. (Fig. 18)

\section{Ricotia davisiana B. L. Burtt (Efe cavlağı) (Olimpos-Beydağları Milli Parkı endemiği)}

Kısa ve basit tüylü, çok yıllık otsu bitkiler. Yapraklar etli, yeşilimsi pulsu, üç yaprakçıklı; segmentler eliptikten dairesel kadar değişen şekillerde. Petaller leylak-pembe renkli. Silikuva meyve şeritsi-dikdörtgenimsi, 6-12 tohumlu. Dünya'da sadece Olimpos-Beydağları Milli Parkı sınırları içinde bulunan Tahtalı Dağı'nın 2000-2300 m’ler arasındaki hareketli kireç taşlı kayalık aralarında yetişmektedir. Türün çiçeklenme zamanı temmuz ayıdır. D. Akd. (Dağ) El. (Fig. 19)

\section{Microthlaspi perfoliatum (L.) F. K. Mey. (Giyle)}

20 cm'ye kadar boylanabilen, tüysüz bir yıllık otsu bitkiler. Taban yapraklar saplı ve mızraksı. Gövde yaprakları mızraksı veya dikdörtgenimsi-mızraksı, gövdeyi sarıcı. Petaller beyaz renkli. Silikula meyve ters kalpsi. Yetişme ortamı olarak deniz seviyesinden başlayarak 2750 m'ye kadar olan yüksekliklerdeki nemli kültür alanları ve nemli toprak alanları tercih eder. Çiçeklenme zamanı ise şubat-mayıs aylarıdır. ÇBFCB.

\section{Familya: Campanulaceae (Çançiçeğigiller)}

\section{Asyneuma michauxioides (Boiss.) Damboldt (Çamdeğneği) (Türkiye endemiği)}

Dik gövdeli, 1 m'ye kadar boylanabilen monokarpik bitkiler. Yapraklar basık tüylü; alt ve gövde yapraklar yumurtamsı-kalpsi. Kaliks lopları şeritsi-biz biçimli, 3-7 $\mathrm{mm}$ boyunda. Korolla lopları 10-14 $\mathrm{mm}$ boyunda, mızraksı solukta azur mavisine kadar değişen renklerde. Kapsül meyve ters konik. Ülkemize özgü olan bu tür, Konya, Denizli, Antalya, Isparta, Burdur ve Niğde illerinde yayılış gösterir. Haziran ayında çiçeklenen bu bitki, 600-2135 m’ler arasındaki çalııkları, çam ormanIarını ve kayalık yerleri tercih eder. D. Akd. El. (Fig. 20)

Campanula involucrata Aucher ex A. DC. (Sarım çanı)

Dik-eğik tırmanışlı, tüylü, 40 cm'ye kadar boylanabilen çok yıllık otsu bitkiler. Taban yaprakları dikdörtgenimsi-eliptik. Gövde yaprakları dikdörtgenimsi-mızraksı. Kaliks lopları dikdörtgenimsi, 4-6 mm boyunda, dik. Korolla dar hunimsi, mavi renkli. Kapsül meyve ters konik. Ülkemizde geniş bir yayılış alanına sahip olan bu bitki, mayıs-temmuz aylarında çiçeklenir. Yetişme ortamı olarak ise 1000-2550 m'ler arasındaki orman açıklıklarda, kireç taşlı kayalıklarda ve yamaçlarda yetişir. ÇBFCB. (Fig. 21)

Campanula podocarpa Boiss. (Kavruk çan) (Türkiye endemiği)

Dik gövdeli (6-)12-20 cm boyunda bir yıllık otsu bitkiler. Yapraklar dikdörtgenimsiden dikdörtgenimsikaşıksıya kadar değişen şekillerde. Korolla mavi renkli, 5-7 mm boyunda. Kapsül meyve geniş, disk şeklinde.

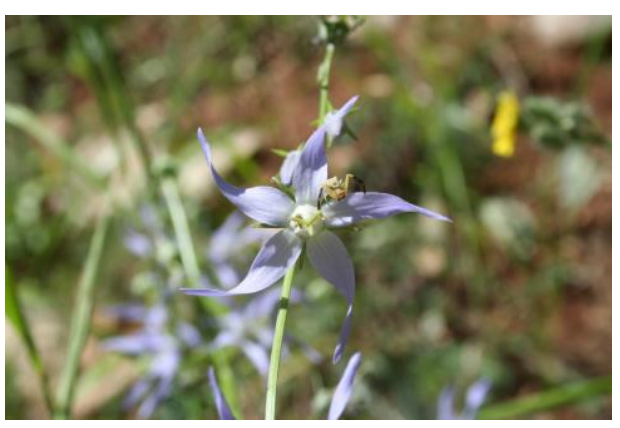

Fig. 20. Asyneuma michauxioides

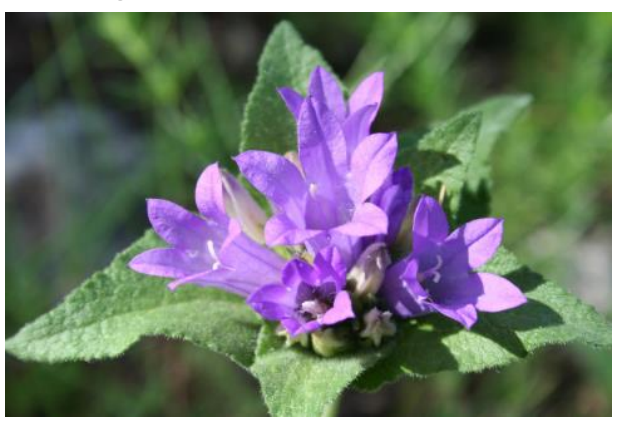

Fig. 21. Campanula involucrata

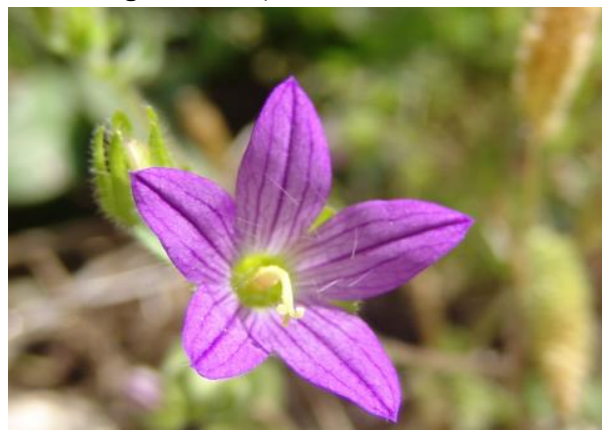

Fig. 22. Campanula podocarpa 
Ülkemize özgü olan bu tür, Antalya, Muğla ve Burdur illerinde yayılış gösterir. Yetişme ortamı olarak deniz seviyesinden başlayarak 1500 m’ye kadar olan yüksekliklerdeki kızılçam orman açıklıklarını ve kaya yarıklarını tercih eder. ÇBFCB. (Fig. 22)

\section{Campanula stricta L. var. libanotica (A. DC.) Boiss. (Gür çançiçeği)}

Kalkık uçlu, 25 cm'ye kadar boylanabilen çok yıllık otsu bitkiler. Alt yapraklar yumurtamsı, dikdörtgenimsi; üst yapraklar mızraksı veya şeritsi mızraksı. Korolla silindirik-hunimsi, mavimenekşe veya koyu mavi. Kapsül meyve ters konik. Haziran-eylül aylarında çiçeklenen bu varyete, 1200-3050 m’ler arasındaki kayalıklarda ve taşlı yamaçlarda yetişir. ÇBFCB.

\section{Familya: Capparaceae (Keberegiller)}

\section{Capparis sicula Veill. subsp. sicula (Deli karpuzu)}

Düzensiz bir şekilde büyüyen çalılar. Yapraklar eliptik veya ters yumurtamsı. Çiçekler gösterişli. Sepaller 4 adet. Petaller beyaz renkli. Stamenler çok sayıda ve uzun. Meyve etli ve çok tohumlu kapsül. Genellikle yol kenarlarında, çam ormanı ve maki açıklıklarında yetişen bu bitki, haziran ve temmuz aylarında çiçeklenir. ÇBFCB.

\section{Familya: Caprifoliaceae (Hanımeligiller)}

\section{Cephalaria cilicica Boiss. \& Kotschy (Boylu pelemir) (Türkiye endemiği)}

1 m'ye kadar boylanabilen narin yapılı bir yıllık otsu bitkiler. Alt yapraklar genellikle basit, mızraksı-eliptik, basık piloz tüylü. Üst yapraklar pinnatisekt parçalı. İnvolukral brakteler yumurtamsı. Reseptakular brakteler dikdörtgenimsi. Kaliks fincan şeklinde. Korolla beyaz veya mavimsi renkli. Meyveli involusel 4 kısa dişli. Ülkemize özgü olan bu tür, sadece Antalya, Muğla ve Adana illerinde yayılış göstermekte olup, haziran ve temmuz aylarında çiçeklenir. Yetişme ortamı olarak ise 30-500 m'ler arasındaki yol kenarlarını, arkları ve kuru çayırlıkları tercih eder. D. Akd. El.

\section{Cephalaria lycica Matthews (Muğla pelemiri)}

\section{(Türkiye endemiği)}

Yatık gövdeli, tabanda kısa odunlu çok yıllık otsu bitkiler. Çiçekli gövdeler 10-40 cm boyunda. Yapraklar derimsi; alt yapraklar basit veya pinnatisekt parçalı. Involukral brakteler geniş yumurtamsı. Reseptakular brakteler dikdörtgenimsi-kaşıksı. Kaliks fincan şeklinde. Korolla beyaz veya menekşe renkli. Meyveli involusel 4 uzun 4 kısa dişli. Ülkemize özgü olan bu tür, Muğla, Antalya ve Isparta illerinde yayılış gösterir. 1700-2200 m’ler arasındaki alpinik stebi, kalkerli kayalıkları, sedir ormanını ve açıklıklarını yetişme ortamı olarak tercih eden bitki temmuz ve ağustos aylarında çiçeklenir. D. Akd. (Dağ) El. (Fig. 23)

\section{Pterocephalus pinardii Boiss. (Yurt cücükotu) (Türkiye endemiği)}

Bodur kümeli, yatık gövdeli, tabanda odunlu çok yıllık bitkiler. Yapraklar dikdörtgenimsiden yumurtamsı-mızraksı. Involukral brakteler mızraksı. Korolla pembe,

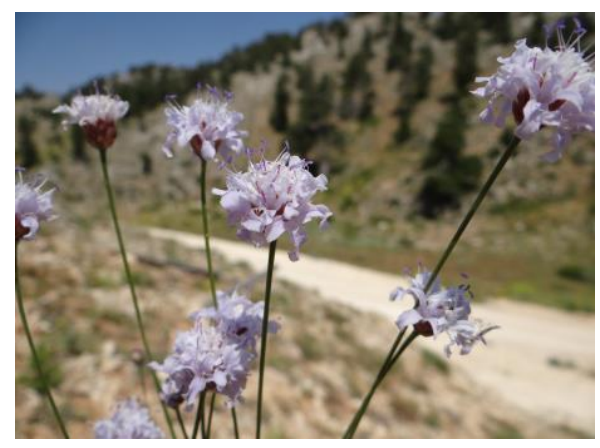

Fig. 23. Cephalaria lycica

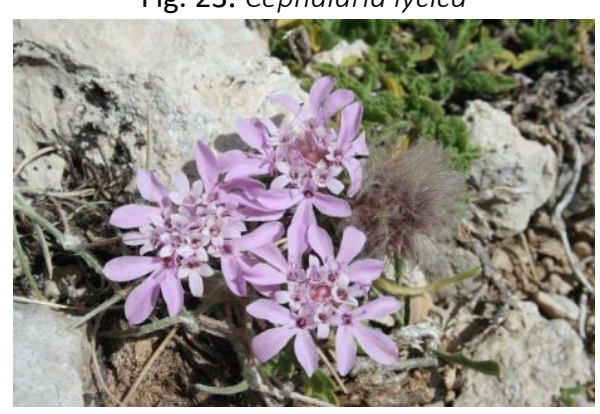

Fig. 24. Pterocephalus pinardii leylak veya mor renkli. Meyveli involusel 4-5 mm boyunda. Korona geniş dişli ve tüylü. Kaliks 1421 setalı. Ülkemize özgü olan bu tür, haziran-ağustos aylarında çiçeklenir. Yetişme ortamı olarak 
ise 1000-2800 m'ler arasındaki kayalık yerleri tercih eder. D. Akd. El. (Fig. 24)

\section{Valeriana dioscoridis Sm. (Çoban zurnası)}

Rizomlu çok yıllık otsu bitkiler. Gövde dik, içi boş ve 1 m'ye kadar boylanır. Taban yaprakları pinnat parçalı; loplar yumurtamsı-dairesel. Gövde yaprakları pinnat parçalı. Çiçekler pembe renkli ve güzel kokulu. Meyve aken. Şubat-mayıs aylarında çiçeklenen bu tür, yetişme ortamı olarak deniz seviyesinden 2300 m'ye kadar olan yüksekliklerdeki kayalık yamaçları ve çalılıkları tercih eder. D. Akd. El. (Fig. 25)

Valerianella vesicaria (L.) Moench (Kuzu gevreği)

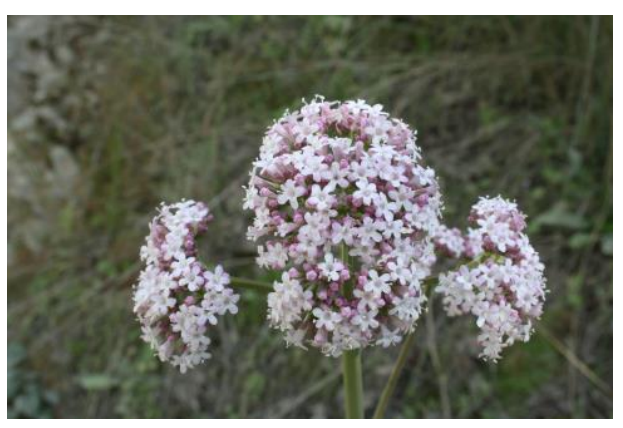

Fig. 25. Valeriana dioscoridis

$30 \mathrm{~cm}$ 'ye kadar boylanabilen bir yıllık otsu bitkiler.

Taban yaprakları kaşıksı veya kamamsı. Çiçek durumu hemen hemen küresel. Çiçekler leylaktan pembemsiye kadar değişen renklerde. Meyve 4-6 × 4-6 mm, şişkin. Bu tür, yetişme ortamı olarak deniz seviyesinden 2000 m'ye kadar olan yüksekliklerdeki kayalık yamaçları ve tarlaları tercih etmekte olup nisan-haziran ayında çiçeklenir. ÇBFCB.

\section{Familya: Caryophyllaceae (Karanfilgiller)}

\section{Cerastium dichotomum L. subsp. dichotomum (Çatal boynuzotu)}

Salgılı tüylü, hemen hemen dik, dallı, 6-20 cm boyunda bir yıllık otsu bitkiler. Yapraklar yumurtamsı-dikdörtgenimsiden mızraksı-dikdörtgenimsiye kadar değişir. Sepaller 7-11 mm boyunda petaller sepallerden kısa, beyaz renkli. Meyve kapsül. Ülkemizde geniş bir yayılış alanına sahip olan bu bitki, nisan-haziran aylarında çiçeklenir. Yetişme ortamı olarak yamaçları, üzüm bağlarını ve kültür alanlarını tercih eder. ÇBFCB.

\section{Dianthus elegans d'Urv. var. actinopetalus (Fenzl)} Reeve (Deli karanfil) (Türkiye endemiği)

10-52 cm boyunda çok yıllık otsu bitkiler. Yapraklar tek veya 2-7'li gruplar halinde. Brakteoller 8'den fazla, şeritsi. Kaliks 18-28 mm boyunda. Petal dudakları pembe, $10 \mathrm{~mm}$ boyunda, ince püsküllü, dişli. Meyve kapsül. Ülkemize özgü olan bu varyete, Antalya, Karaman ve Mersin illerinde yayılış gösterir. 10001800 m’ler arasındaki kayalıkları ve kaya yarıklarını tercih etmekte olup, temmuz-eylül aylarında çiçekle-

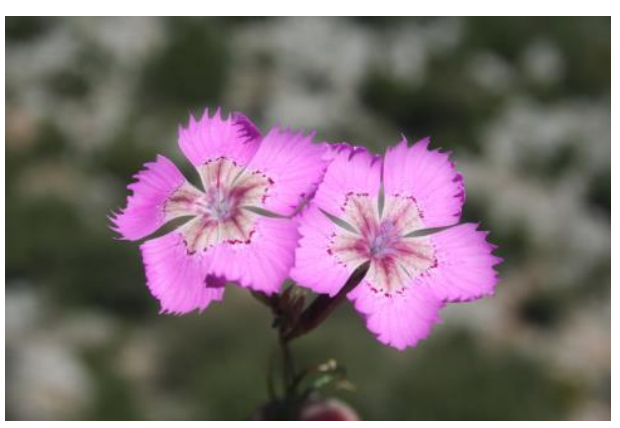

Fig. 26. Dianthus elegans var. actinopetalus nir. Akd. El. (Fig. 26)

\section{Minuartia dianthifolia (Boiss.)Hand.-Maz. var. dianthifolia (Deli tıstıs) (Türkiye endemiği)}

Kümeli veya yastık formunda, yarı çalımsı çok yıllık bitkiler. Yapraklar mızraksıdan şeritsimızraksıya kadar değişir. Sepaller 6-8(-9) mm boyunda, yumurtamsı-mızraksıdan mızraksıya kadar değişir. Petaller beyaz renkli. Meyve kapsül. Ülkemize özgü olan bu bitki, sadece Antalya ve Muğla illerinde yetişir. Yetişme ortamı olarak ise 2000 m’nin üzerindeki taşlık stebi tercih etmekte olan bu bitki haziran ve temmuz aylarında çiçeklenir. Ir.-Tur. El.

\section{Paronychia carica Chaudhri var. stipulata Chaudhri (Koç kepekotu) (Türkiye endemiği)}

Yatık gövdeli, kümeli, çok yıllık otsu bitkiler. Yapraklar dar eliptikten ters yumurtamsı-ters mıraksıya kadar değişen şekillerde. Stipüller yapraklardan kısa. Çiçekler 3-3.5 mm boyunda. 
Dıştaki sepaller içtekilerden uzun; darca dikdörtgenimsi. Ülkemize özgü olan bu varyete, mayıstemmuz aylarında çiçeklenir ve yetişme ortamı olarak 100-1000 m’ler arasındaki kalkerli kayalık yerleri tercih eder. ÇBFCB.

Paronychia chionaea Boiss. subsp. chionaea var. chionaea (Deli kepekotu)

Çoğunlukla tabanda odunsu, yatık gövdeli, kümeli, çok yıllık otsu bitkiler. Yapraklar ters yumurtamsı-kaşıksı. Brakteler geniş yumurtamsıdan dikdörtgenimsiye kadar değişen şekillerde. Çiçekler 2.5-3.25 mm boyunda. Sepaller dar dikdörtgenimsi. Meyve sepallere eşit. Çiçeklenme zamanı ise haziran-ağustos ayları olan bu bitki, 2800 m'ye kadar olan yüksekliklerdeki kayalık yerler tercih eder. ÇBFCB.

\section{Saponaria dalmasii Boissieu (Has sabunotu) (Türkiye endemiği)}

Dallı, dik veya yatık tırmanışlı, $10-25 \mathrm{~cm}$ boyunda bir yıllık otsu bitkiler. Alt yapraklar geniş ters yumurtamsı. Gövde yaprakları darca ters yumurtamsı. Kaliks dar dikdörtgenimsi-silindirik. Petaller gül renkli. Kapsül meyve yumurtamsı-dikdörtgenimsi. Ülkemize özgü olan bu tür, Antalya-Çıralı ve Isparta-Davraz Dağ’ında yetişmektedir. Nisan-haziran ayında çiçeklenen bu tür, serpantin alanları ve kayalık yerleri tercih eder. D. Akd. El. (Fig. 27)

\section{Silene behen L. (Ak kıvşak)}

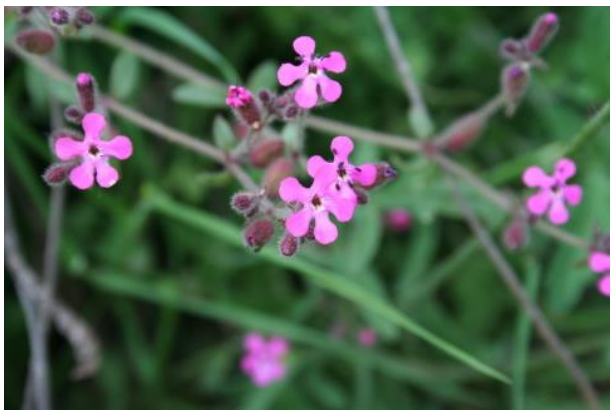

Fig. 27. Saponaria dalmasii

Tamamen çıplak bir yıllık otsu bitkiler. Gövde dik, 10-90 cm boyunda. Alt yapraklar ters yumurtamsı-kaşıksı veya ters mızraksı. Kaliks 11-14 mm boyunda, belirgin damarlı. Petaller pembe renkli. Antofor 2-2.5 mm boyunda. Kapsül meyve yumurtamsı. Nisan ve mayıs aylarında çiçeklenen bu tür, yetişme ortamı olarak deniz seviyesinden başlayarak 1400 m'ye kadar olan yüksekliklerdeki yamaçları ve tarlaları tercih eder. ÇBFCB.

\section{Silene cryptoneura Stapf. (Özge Nakıl) (Türkiye endemiği)}

Hemen hemen dik gövdeli, yayılmış uzun tüylü, 10-25 $\mathrm{cm}$ boyunda bir yıllık otsu bitkiler. Taban yaprakları saplı, kaşıksı. Gövde yaprakları ters yumurtamsı- veya dikdörtgenimsi-ters yumurtamsı. Kaliks $14-20 \mathrm{~mm}$ boyunda. Petaller pembe renkli, tam kenarlı. Antofor 8 mm'ye kadar çıkar. Meyve kapsül. Ülkemize özgü olan bu tür, sadece Antalya, Muğla ve Burdur illerinde yayılış göstermekte olup nisan ayında çiçeklenir. Yetişme ortamı olarak ise kayalık yerleri tercih eder. D. Akd. El. (Fig. 28)

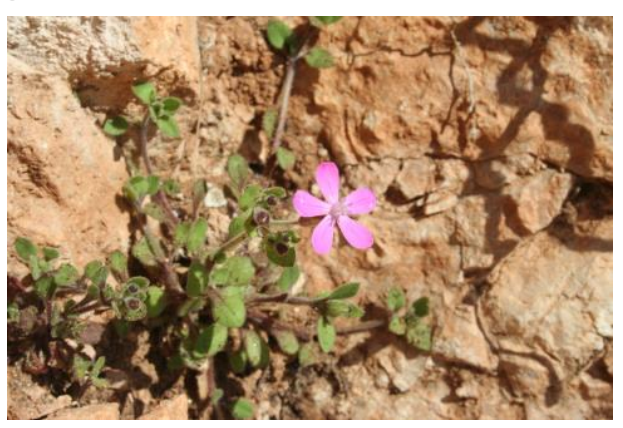

Fig. 28. Silene cryptoneura

\section{Silene vulgaris (Moench) Garcke var. Vulgaris (Ecibücü)}

Çoğunlukla tabanda odunsu, çok yıllık otsu bitkiler. Gövde dallı, çıplak veya tüylü, 80 cm'ye kadar boylanabilir. Yapraklar yumurtamsı-mızraksı, mızraksı veya ters yumurtamsı. Kaliks $13-21 \mathrm{~cm}$, şişkin, yeşilimsi. Petaller beyaz renkli, derin iki parçalı. Antofor 2-4 mm boyunda. Kapsül meyve 12 mm'den kısa. Mayıs-ağustos aylarında çiçeklenen bu varyete, yetişme ortamı olarak ise deniz seviyesinden başlayarak 3000 m'ye kadar olan yüksekliklerdeki çalılıkları, yamaçları ve açık alanları tercih eder. ÇBFCB. 
Telephium imperati L. subsp. orientale (Boiss.) Nyman (Zulzula)

Yatık gövdeli, 10-30 cm boyunda, çıplak çok yıllık otsu bitkiler. Yapraklar sarmal dizilişli, eliptikters yumurtamsı. Kimöz çiçek durumu çok sayıda kısa saplı çiçekli. Sepaller 3-5 mm boyunda, dikdörtgenimsi-şeritsi. Petaller hemen hemen sepaller kadar ve beyaz renkli. Kapsül meyve üçgenimsi-piramidal, kahve renkli-yeşil, parlak. 400-2200 metre arasındaki kuru kayalık yamaçlarda, kaya yarıklarında, çam ormanlarında ve meşe çalılıklarında yetişen bu alt tür, mayıstemmuz aylarında çiçeklenir. ÇBFCB.

Vaccaria hispanica (Mill.) Rauschert (Ekin ebesi)

Dik gövdeli, çıplak, 15-60 cm boyunda bir yıllık otsu bitkiler. Yapraklar kalpsi-mızraksı. Kaliks 10$15 \mathrm{~mm}$ boyunda. Petaller pembe renkli, 18-23 mm boyunda. Kapsül meyve hemen hemen küresel. Bu tür, yetişme ortamı olarak deniz seviyesinden 1600 m'ye kadar olan yüksekliklerdeki tarlaları ve stebi tercih eder. Çiçeklenme zamanı ise mayıs-temmuz aylarıdır. ÇBFCB.

Familya: Cistaceae (Ladengiller)

\section{Fumana arabica (L.) Spach (Arap güneşotu)}

10-25 cm boyunda çok yıllık bitkiler. Yapraklar sarmal dizilişli, dikdörtgenimsi-eliptik. Çiçekler sarı renkli. Meyve kapsül. Illk kez Arabistan'dan toplanarak bilim dünyasına tanıtılan bu tür, yetişme ortamı olarak deniz seviyesinden 1000 m'ye kadar olan yüksekliklerdeki makilik alanlardaki kireç taşlı ve tebeşirli tepeleri, friganayı ve çam ormanlarını tercih eder. Çiçeklenme zamanı ise mart-haziran aylarıdır. ÇBFCB. (Fig. 29)

Familya: Convolvulaceae (Tarla sarmaşığıgiller)

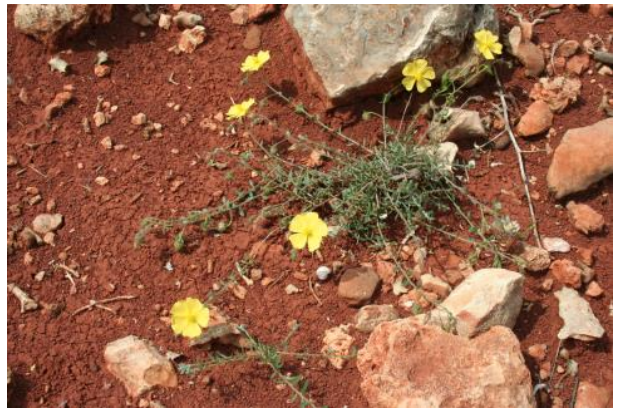

Fig. 29. Fumana arabica

\section{Convolvulus scammonia L. (Bingözotu)}

Tüysüz yükselici bitkiler. Yapraklar ok başlı veya tabanda zıpkınsı. Çiçekler tek veya 2-7 çiçekli. Korolla kremden soluk sarıya kadar değişen renklerde, 30-45 mm. Meyve kapsül. Kireç taşlı meşe çalıılarında, makiliklerde ve kültür alanlarında yetişen bu tür, nisan-temmuz aylarında çiçeklenir. D. Akd. El.

\section{Cuscuta campestris Yunck. (Kafirsaçı)}

Sarı veya beyazımsı gövdeli parazit bitkiler. Çiçek durumu küresel, genellikle çok çiçekli ve yoğun. Çiçekler 2-3 mm, beyaz, krem veya kısmen kırmızı renkli. Kapsül meyve basık-küresel, 2-4 tohumlu. Tarla ve bahçelerdeki değişik bitkiler üzerinde parazit olarak yaşayan bu tür, (mayıs-) haziran-ekim aylarında çiçeklenir. ÇBFCB.

Familya: Crassulaceae (Damkoruğugiller)

\section{Rosularia libanotica (Strand ex L.) Samuelsson (Arap kayakoruğu)}

Çok yıllık otsu bitkiler. Çiçek kümesi gövdesi 10-30 cm boyunda. Yapraklar kaşıksı. Çiçek durumu seyrek, 2-120 çiçekli. Korolla 4-5 mm boyunda. Korolla beyazdan pembeye kadar değişen şekillerde. Folikül meyve $4 \mathrm{~mm}$ boyunda. Haziran-ağustos aylarında çiçeklenen bu bitki, yetişme ortamı olarak 100-2400 m’ler arasındaki kayalık makilikleri, ormanlık alanları, duvarları ve kaya yarıklarını tercih eder. D. Akd. El. 


\section{Sedum album L. (Çobankavurgası)}

Seyrek kümemsi çok yıllık otsu bitkiler. Çiçekli gövdeler $5-20 \mathrm{~cm}$ boyunda. Yapraklar şeritsi-silindirikten yumurtamsı-küresele kadar değişen şekillerde. Çiçek durumu seyrek, çok çiçekli. Petaller beyaz veya pembe renkli. Folikül meyve dik, çıplak. Ülkemizde oldukça geniş bir yayılış alanına sahip olan bu tür, yetişme ortamı olarak 100-2500 m'ler arasındaki duvarları, kayalık yamaçları ve kaya yarıklarını tercih eder. Çiçeklenme zamanı ise haziraneylül aylarıdır. ÇBFCB. (Fig. 30)

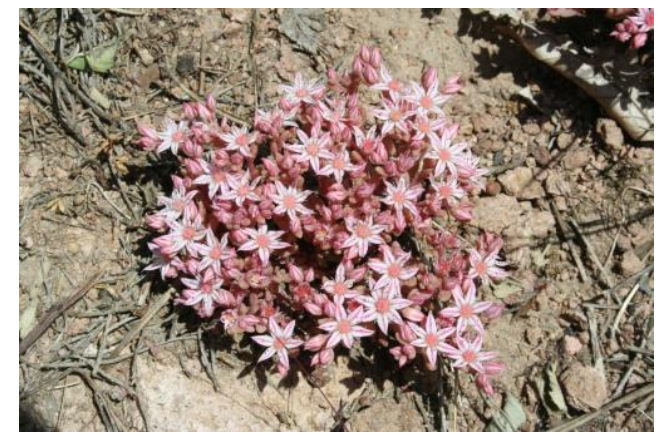

Fig. 30. Sedum album

\section{Sedum urvillei DC. (Çıbanotu)}

Küçük, kümemsi, çıplak çok yıllık otsu bitkiler. Yapraklar üçgenimsi-yumurtamsı, 4-6 mm boyunda. Çiçek durumu seyrek kimöz, 3-10 çiçekli. Sepaller $4 \mathrm{~mm}$. Petaller sarı renkli, 5-8 mm boyunda. Ülkemiz dışında Balkanlarda yetişen bu bitki, yetişme ortamı olarak deniz seviyesinden başlayarak 1300 m’ye kadar olan yüksekliklerdeki kireç taşlı kayalık yerleri tercih eder. Çiçeklenme zamanı ise haziran ve temmuz aylarıdır. ÇBFCB.

\section{Familya: Cucurbitaceae (Kabakgiller)}

\section{Bryonia cretica L. (Haylin)}

Çok yıllık tırmanıcı bitkiler. Yapraklar yumurtamsı-kalpsi, derin 5-7 loplu; loplar mızraksı veya yumurtamsı. Sülükler dallanmamış. Çiçekler yeşilimsi-sarı veya yeşilimsi-beyaz renkli. Meyve küçük, üzümsü, küresel, kırmızı renkli. Mayıs ayında çiçeklenen bu tür değişik çalıların üzerinde yaşar. D. Akd. El.

\section{Ecballium elaterium (L.) A. Rich. (Eşekhıyarı)}

$25 \mathrm{~cm}$ 'ye kadar boylanabilen, yatık gövdeli, sert kıllı, çok yıllık otsu bitkiler. Yapraklar kalın, pürüzlü, yumurtamsı-üçgenimsi. Erkek çiçekler salkım durumunda. Dişi çiçekler tek. Petaller soluk sarı renkli. Üzümsü meyve sarkık, dikdörtgenimsi-elipsoid, sert tüylü. 600 m'ye kadar olan nemli yerlerde, yol kenarlarında ve nehir yataklarında yetişen bu tür, nisanekim aylarında çiçeklenir. Akd. El. (Fig. 31)

\section{Familya: Euphorbiaceae (Sütleğengiller)}

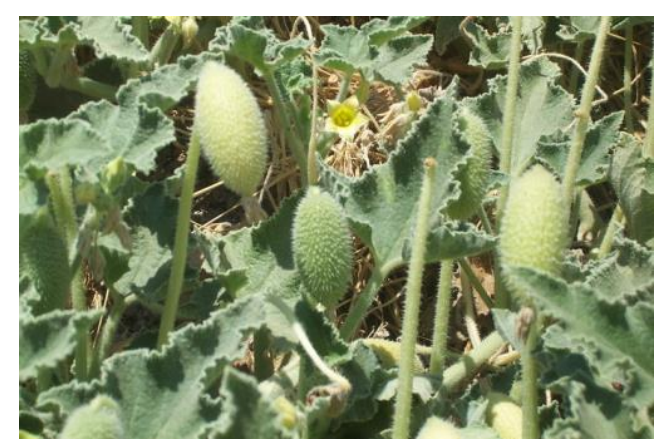

Fig. 31. Ecballium elaterium

\section{Euphorbia exigua L. subsp. exigua (Güdük sütleğen)}

Çıplak, 20 cm'ye kadar boylanabilen, dallı bir yıllık otsu bitkiler. Gövde ve ışın yaprakları şeritsiden şeritsi-dikdörtgenimsiye kadar değişen şekillerde veya şeritsi-mızraksı. Çiçek durumu siyatyum. Meyve kapsül ve 3 loplu. Ülkemizde Marmara, Ege ve Akdeniz Bölgeleri'nde yayllı̧ gösteren bu varyete, mart-temmuz aylarında çiçeklenir. Yetişme ortamı olarak deniz seviyesinden 1400 m’ye kadar olan yüksekliklerdeki kızılçam açıkıklarını, kayalık yerleri ve tarlaları tercih eder. ÇBFCB.

\section{Euphorbia helioscopia L. subsp. helioscopia (Feribanotu)}

40 cm'ye kadar boylanabilen bir yıllık otsu bitkiler. Gövde yaprakları ters yumurtamsı-kaşıksı. Işın yaprakları ters yumurtamsı. Çiçek durumu siyatyum. Meyve kapsül ve 3 loplu. Şubat-haziran 
ayında çiçeklenen bu alt tür, yetişme ortamı olarak deniz seviyesinden başlayarak 1400 m'ye kadar olan yüksekliklerdeki kireç taşlı kayalıkları, yamaçları, tarlaları ve nemli yerleri tercih eder. ÇBFCB.

Familya: Fabaceae (Baklagiller)

Acacia saligna (Labill.) Wendl. (Kıbrıs akasyası)

Dalları aşağıya doru sarkık duruşlu, 6 m’ye kadar boylanabilen ağaçlar veya çalı görünüşlü küçük ağaçlar. Yapraklar şeritsi-mızraksı. Korolla yuvarlak başçılarda, sarı renkli ve küçük. Baklamsı meyve 10-12 cm boyunda, kahverenkli. Bu tür, erozyonla mücadele için ülkemize Avustralya'dan getirilen bir türdür. Derine giden kök sistemi ile toprağı tutar. ÇBFCB.

\section{Genista januensis Viv. subsp. Iydia (Boiss.) Kit Tan \& Ziel. (Geyik borçağı)}

Dik veya yatık gövdeli çalılar. Yapraklar basit, şeritsi, ters mızraksı. Kaliks çan şeklinde. Korolla sarı renkli. Baklamsı meyve darca dikdörtgenimsi. Nisan-haziran aylarında çiçeklenen bu varyete, yetişme ortamı olarak 300-2100 m'ler arasındaki kayalık yamaçları ve makilik alanları tercih eder. D. Akd. El.

\section{Glycyrrhiza echinata L. (Pıtırak meyan)}

1(-2) m'ye kadar boylanabilen çok yıllık otsu bitkiler. Yapraklar imparipinnat parçalı; yaprakçıklar 4-8 parçalı, mızraksıdan geniş̧̧e eliptiğe kadar değişir. Çiçek durumu küreselden uzamışa kadar değişir, 2-5 $\mathrm{cm}$, kaliks dişleri $1 \mathrm{~mm}$ boyunda. Korolla 5-7 mm boyunda, beyazdan leylak rengine kadar değişir. Baklamsı meyve, 12-16 mm boyunda, basık, dikenli, kırmızı kahve renkli. Haziran ve temmuz aylarında çiçeklenen bu tür, 1250 m'ye kadar olan yüksekliklerdeki bataklıklarda, ark kenarlarında ve kuru çayırlıklarda yetişir. ÇBFCB. (Fig. 32)

Lathyrus aphaca L. var. pseudoaphaca (Boiss.)P. H. Davis (Sarı burçak)

Narin yapılı tırmanıcı ve yükselici bir yıllık otsu bitkiler. Gövde kanatsız ve tüysüz. Korolla krem veya soluk sülfür sarısı renkli. Meyve şeritsi-dikdörtgenimsi, çıplak. Bu varyete, yetişme ortamı olarak deniz seviyesinden 1700 m'ye kadar olan kayalık kireçtaşı yamaçlarını, tarlaları, nehir yataklarını tercih

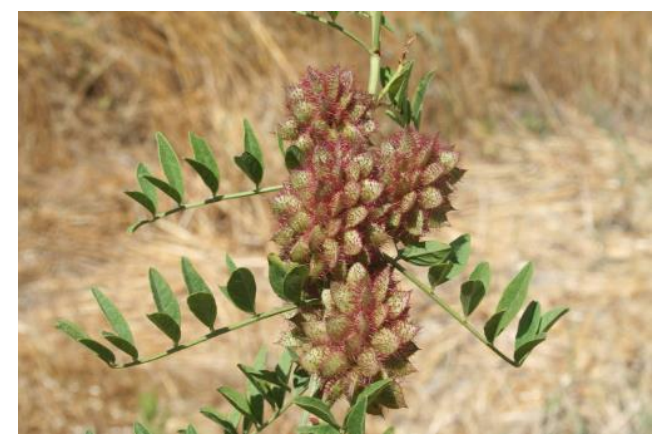

Fig. 32. Glycyrrhiza echinata

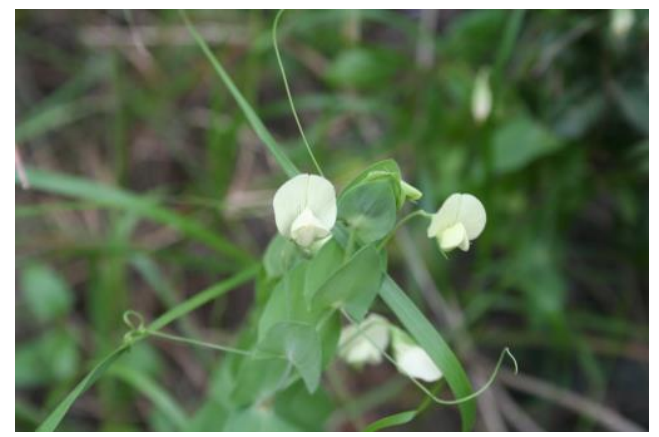

Fig. 33. Lathyrus aphaca var. pseudoaphaca etmekte olup, mart-haziran ayları arasında çiçeklenir. Akd. El. (Fig. 33)

Lotus corniculatus L. var. tenuifolius L. (Gazalboynuzu)

50 cm'ye kadar boylanabilen yükselici, eğik tırmanışlı, stolonlu, çok yıllık otsu bitkiler. Yaprakçıklar dar mızraksı veya mızraksı. Korolla sarı veya kırmı renkli. Baklamsı meyve düz. Bu varyete yetişme ortamı olarak deniz seviyesinden 2500 m'ye kadar olan yüksekliklerdeki dağlık yamaçları ve makilikleri tercih eder. ÇBFCB.

\section{Lotus halophilus Boiss. \& Spruner (Çorak gazalboynuzu)}

Küçük, basık tüylü, sürünücü, 5-12(-15) cm boyunda bir yıllık otsu bitkiler. Yaprakçıklar yumurtamsı, ters yumurtamsı veya dikdörtgenimsi. Şemsiye çiçek durumu 1-2(-3) çiçekli. Korolla 
soluk sarı renkli. Baklamsı meyve $20-40 \mathrm{~mm}$ boyunda. Kumlu toprakları ve kumulları yetişme ortamı olarak tercih eden bu tür, mart-nisan ayında çiçeklenir. ÇBFCB.

\section{Medicago sativa L. subsp. sativa (Kara yonca)}

15-70 cm boyunda çok yıllık otsu bitkiler. Gövde dik, yatık veya eğik tırmanışlı. Alt yaprakçıklar ters yumurtamsı; üst yaprakçıklar ise kamamsı-ters mızraksıdan şeritsi-mızraksıya kadar değişen şekillerde. Çiçekler 6-12 mm boyunda koyu menekşe veya soluk lavanta renkli. Meyve spiral, ağsı damarlı. Nisan-eylül aylarında çiçeklenen bu tür, 2500 m’ye kadar olan yüksekliklerdeki stepte, kayalık ve çimenlik olan yamaçlarda, kum tepelerinde, tarlalarda ve yol kenarlarında yetişir. ÇBFCB.

\section{Onobrychis oxyodonta Boiss. var. oxyodonta (Kır korungası)}

Çok yıllık, 60 cm'ye kadar boylanabilen sürünücü veya eğik tırmanışlı otsu bitkiler. Yapraklar parçalı; yaprakçıklar şeritsiden şeritsi eliptiğe kadar değişen şekillerde. Korolla pembe renkli. Meyve dikenli. Mayıs-ağustos aylarında çiçeklenen bu tür, yetişme ortamı olarak 200-2000 m’ler arasındaki yol kenarlarını, makilik alanları, sedir-çam ormanlarını tercih eder. ÇBFCB. (Fig. 34)

\section{Ononis reclinata L. (Şeytan taburesi)}

Tabanda dallı, bir yıllık otlar. Gövde salgılı tüylü, 5-20 cm boyunda. Yapraklar 3 yaprakçıkl; yaprakçıklar ters yumurtamsıdan dikdörtgenimsiye kadar değişen şekillerde. Korolla pembe'den mor'a kadar değişen renklerde. Baklamsı meyve şeritsi-dikdörtgenimsi, salgılı tüylü. Nisanhaziran aylarında çiçeklenen bu tür yetişme ortamı olarak, deniz seviyesinden 500 m'ye kadar olan yüksekliklerdeki taşlı yamaçları, kireç taşı kayalıklarını ve deniz kumullarını tercih eder. Akd. El.

\section{Scorpiurus subvillosus L. var. subvillosus (Koyundücüğü)}

Yatık gövdeli, bir yıllık otsu bitkiler. Yapraklar ters mızraksı. Kaliks kısa çansı. Korolla sarı veya turuncu renkli. Meyve boğumlu bakla. Bu tür nisan-mayıs aylarında çiçeklenir. Yetişme ortamı olarak ise deniz seviyesinden 800 m’ye kadar olan yüksekliklerdeki kayalık yamaçları ve tarlaları tercih eder. ÇBFCB. (Fig. 35)

\section{Trifolium angustifolium L. (Nefel)}

50 cm'ye kadar boylanabilen dik veya yükselici bir yıllık otsu bitkiler. Yaprakçıklar darca şeritsi mızraksı. Korolla mor'dan beyaz'a kadar değişen renklerde. Mart ve nisan aylarında çiçeklenen bu tür, yetişme ortamı olarak ise deniz seviyesinden 700 m'ye kadar olan yüksekliklerdeki stebi, tarlaları kumlu yerleri tercih eder. ÇBFCB. (Fig. 36)

\section{Trifolium physodes Stev. ex Bieb. var. physodes (Meşe üçgülü)}

$50 \mathrm{~cm}$ 'ye kadar boylanabilen çok yıllık otsu bitkiler. Yaprakçıklar eliptikten ters yumurtamsıya kadar değişen şekillerde. Kaliks meyveli halde şişkin. Korolla pembe renkli. Meyve baklamsı tipte. Mayıs-temmuz aylarında çiçeklenen bu varyete yetişme ortamı olarak deniz seviyesinden 2200 m’ye kadar olan yüksekliklerdeki açık alanları ve orman açıkıklarını tercih eder. ÇBFCB. (Fig. 37)

\section{Vicia cassia Boiss. (Mor bakla)}

20-40 cm boyunda, tırmanıc bir yıllık otsu bitkiler. Yaprakçıklar 4-7 parçalı, şeritsi-eliptikten şeritsiye kadar değişen şekillerde. Çiçekler 15-22 mm boyunda, menekşe renkli. Kaliks 5-7 mm boyunda. Baklamsı meyve dikdörtgenimsi-şeritsi, 20-33 mm boyunda. Nisan-haziran ayında çiçeklenen bu tür, yetişme ortamı olarak deniz seviyesinden 1000 m’ye kadar olan yüksekliklerdeki makilikleri, ormanları ve kayalık yamaçları tercih eder. D. Akd. El. 


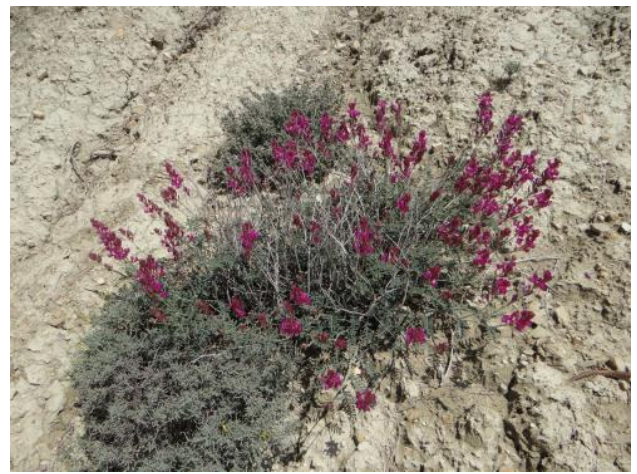

Fig. 34. Onobrychis oxyodonta var. oxyodonta

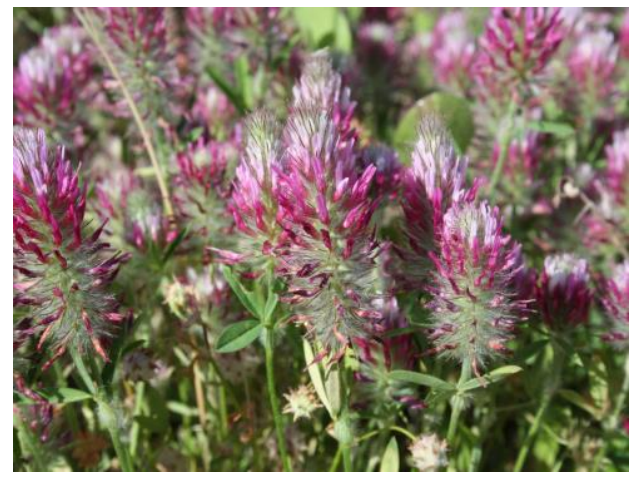

Fig. 36. Trifolium angustifolium

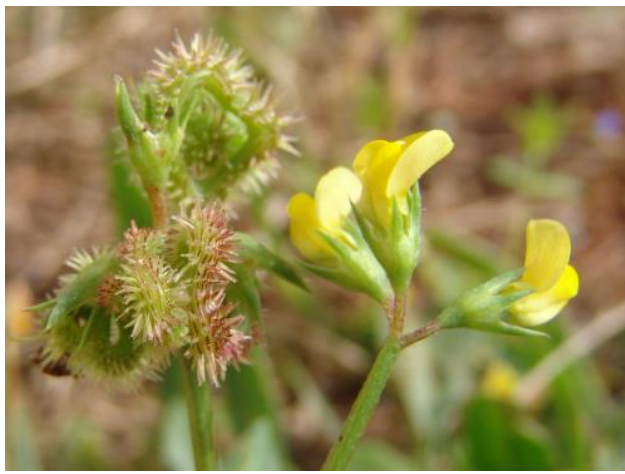

Fig. 35. Scorpiurus subvillosus var. subvillosus

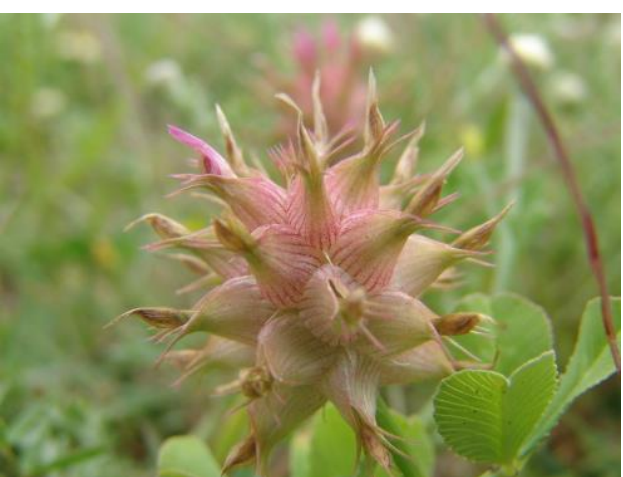

Fig. 37. Trifolium physodes var. physodes

Familya: Geraniaceae (Turnagagasıgiller)

\section{Geranium rotundifolium L. (Helilok)}

Tabanda dallı, yumuşak tüylü, 10-50 cm bir yıllık otsu bitkiler. Alt yapraklar elsi parçalı; segmentler kamamsı. Sepaller 3.5-5 mm boyunda. Petaller pembe veya leylak renkli. Merikarp meyve tüylü. Yetişme ortamı olarak deniz seviyesinden 1700 m'ye kadar olan yüksekliklerdeki kayalık ve nemli yerleri tercih eden bu bitki, mart-mayıs aylarında çiçeklenir. ÇBFCB.

\section{Familya: Hypericaceae (Kantarongiller)}

\section{Hypericum bourgaei (Boiss.) N. Robson (Cüce kantaron) (Türkiye endemiği)}

Sürünücü veya kalkık uçlu gövdeli, 5-20(-28) cm boyunda çok yıllık otsu bitkiler. Yapraklar dikdörtgenimsi veya eliptip-ters yumurtamsı. Petaller 8-15 mm boyunda, sarı renkli, siyah benekli. Kapsül meyve 5-10 cm boyunda. Ülkemize özgü olan bu bitki, Antalya, Denizli, Konya ve Kütahya illerinde yayılış gösterir. Mayıs-ağustos aylarında çiçeklenen bitki, yetişme ortamı olarak 1350-2300 m'ler arasındaki kuru kayalık ve taşlık yerleri tercih eder. D. Akd. (Dağ) El.

Hypericum perforatum L. subsp. veronense (Schrank) H. Linb. (Sarı kantaron)

10-110 cm boyunda, dik gövdeli çok yıllık otsu bitkiler. Yapraklar dar yumurtamsı, şeritsi veya mızraksıdan eliptik-dikdörtgenimsiye kadar değişen şekillerde. Petaller (5-) 8-15 mm boyunda, sarı renkli, siyah benekli. Kapsül meyve yumurtamsıdan piramidale kadar değişen şekillerde. Ülkemizde

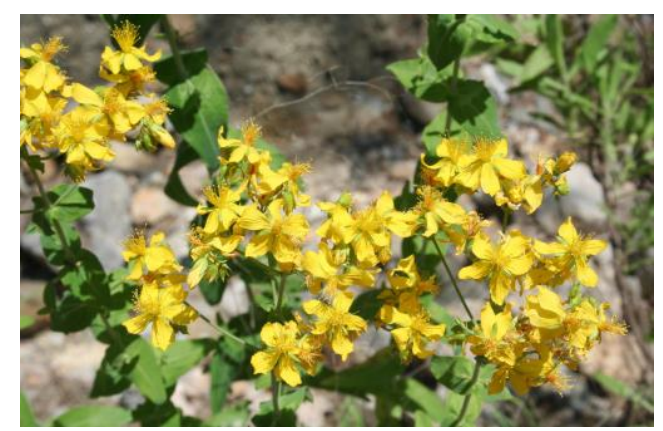

Fig. 38. Hypericum perforatum subsp.veronense 
oldukça geniş bir yayılış alanına sahip olan tür, yetişme ortamı olarak deniz seviyesinden 2500 m'ye kadar olan yüksekliklerdeki kuru alanları veya nemli yerleri tercih eder. Çiçeklenme zamanı ise (nisan-)mayıs-eylül(-ekim) aylarında çiçeklenir. ÇBFCB. (Fig. 38)

Familya: Juglandaceae (Cevizgiller)

\section{Juglans regia L. (Ceviz)}

30 m'ye kadar boylanabilen ağaçlar. Yapraklar aromatik, imparipinnat; yaprakçıklar eliptikten ters yumurtamsıya veya dikdörtgenimsi-yumurtamsıya kadar değişen şekillerde. Erkek çiçekler tek, kedicik, çok çiçekli ve sarkık. Dişi çiçekler birkaç çiçekli salkımlarda. Eriksi meyve yarı küresel. Ülkemizde geniş bir yayılış alanı olan ve kültürü yapılan ceviz, mayıs ayında çiçeklenir. Yetişme ortamı olarak ise deniz seviyesinden 1550 m'ye kadar olan yüksekliklerdeki meşe ve karışık ormanları, kalkerli kayalık yamaçları zengin alüvyonal toprakları ve vadi içlerini tercih eder. ÇBFCB.

\section{Familya: Lamiaceae (Ballıbabagiller)}

\section{Ajuga chamaepitys (L.) Schreber subsp. chia (Schreber) Arcangeli (AcIgıcı)}

Yatık gövdeli veya eğik tırmanışlı bitkiler. Gövde yaprakları derin 3 loplu. Korolla sarı renkli. Fındıksı meyve buruşuk. Ülkemizde oldukça geniş bir yayılış alanına sahip olan bu bitki, nisantemmuz aylarında çiçeklenir. Yetişme ortamı olarak deniz seviyesinden 1700 m'ye kadar olan yüksekliklerdeki taşı yamaçları, üzüm bağlarını ve nemli alanları tercih eder. ÇBFCB.

\section{Ballota glandulosissima Hub.-Mor. \& Patzak (Leylimotu)}

\section{(Türkiye endemiği)}

Tabanda odunlu ve eğik tırmanışı bitkiler. Gövde yapışkan tüylü, 15-40 (-50) cm boyunda. Gövde yaprakları yarı kalpsi. Çiçek durumları 4-10 çiçekli. Korolla soluk pembe. Meyve fındıksı. Antalya ve Muğla illerine özgü olan bu tür, temmuz ayında çiçek açar. Yetişme ortamı olarak ise 50-900 m'ler arasındaki kireçtaşı kayalıklarını tercih eder. D. Akd. El. (Fig. 39)

Calamintha menthifolium (Host) Stace subsp. ascendens (Jord.) Govaerts (Leylak fesleğeni)

$70 \mathrm{~cm}$ 'ye kadar boylanabilen eğik tırmanışı veya dik gövdeli çok yıllık otlar. Yapraklar yumurtamsıdan genişçe yumurtamsıya kadar değişen şekillerde. Çiçek durumları (4-)6-14 adet. Korolla leylak

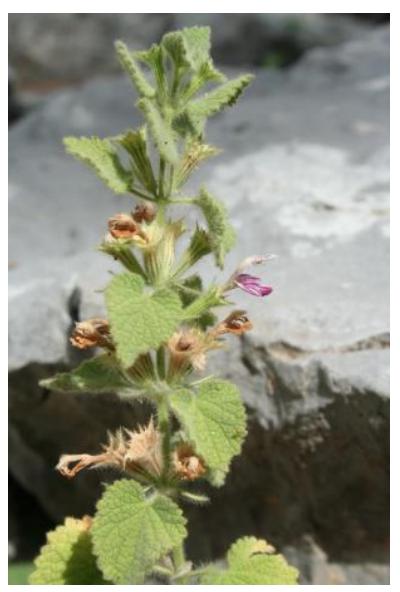

Fig. 39. Ballota glandulosissima mavi'den leylak rengine kadar değişen renklerde. Bu alt tür, eylül ve ekim aylarında çiçek açar ve yetişme ortamı olarak ise 50-500 m’ler arasındaki yüksekliklerdeki çalıları ve nehir kenarlarını tercih eder. Avr.-Sib. El.

\section{Clinopodium graveolens (M. Bieb.) subsp. graveolens (Filiskin)}

Dik ya da kalkık uçlu bir yıllık otsu bitkiler. Gövde çoğunlukla uzun tüylü, 3-30 cm buyunda. Yapraklar mızraksı-yumurtamsı veya ters yumurtamsı-dairesel, tüylü. Kaliks 5-9 mm boyunda. Korolla mor, pembe veya mavi renkli. Fındıksı meyve ters yumurtamsıdan dikdörtgenimsiye kadar değişen şekillerde. Ülkemizin iç ve batı kesimlerinde oldukça geniş bir yayılış alanına sahip olan bu alt tür, nisan-ağustos aylarında çiçeklenir. Yetişme ortamı olarak ise deniz seviyesinden 1700 m’ye kadar olan yüksekliklerdeki özellikle kalkerli kayalık yamaçları, stebi, çayırlık alanları ve tarlaları tercih eder. ÇBFCB. 
Lamium album L. subsp. album (Balıcak)

17-60 cm boyunda, stolonlu, dik veya eğik tırmanışlı çok yıllık otsu bitkiler. Yapraklar genişçe yumurtamsı. Çiçek durumları 8-10 çiçekli. Kaliks 9-15 mm boyunda. Korolla beyaz renkli. Fındıksı meyveler koyu kahverengi veya grimsi kahverengi. Nisan-ağustos aylarında çiçeklenen bu beyaz çiçekli balıcak yetişme ortamı olarak deniz seviyesinden 3100 m'ye kadar olan yüksekliklerdeki çam, göknar ormanlarını, meşe çalılıklarını ve kayalık yamaçları tercih eder. Avr.-Sib. El. (Fig. 40)

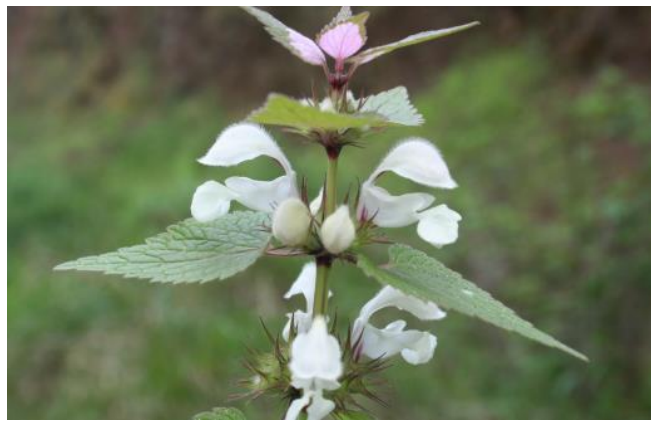

Fig. 40. Lamium album subsp. album

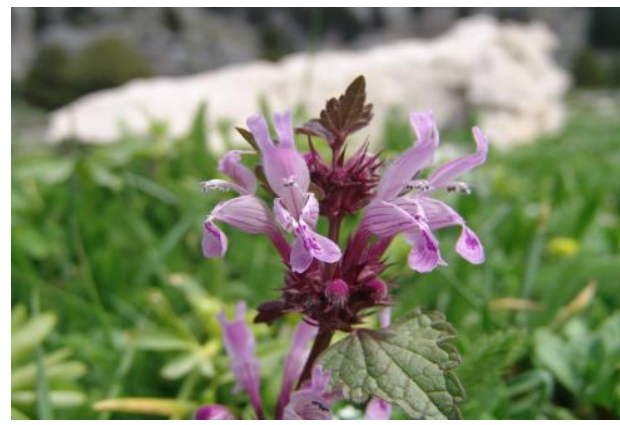

Fig. 41. Lamium garganicum subsp. striatum var. striatum

Lamium garganicum L. subsp. striatum (Sm.) Hayek var. striatum (Tel balıcak) (Montbret \& Aucher ex Bentham) (Ballıbaba)

6-45 cm boyunda çok yıllık otsu bitkiler. Yapraklar genişçe yumurtamsıdan böbreksiye kadar değişen şekillerde. Çiçek durumları 8(-12) çiçekli. Kaliks tüpsü, 8-18 mm boyunda. Korolla morpembe, nadiren beyaz renkli. Fındıksı meyveler siyahımsı-yeşil veya kahverengi. Ülkemiz dışında Kafkasya, kuzey-batı İran ve kuzey Irak'ta da yetişen bu varyete, nisan-eylül ayları arasında çiçeklenir. Yetişme ortamı olarak ise 400-2300 m’ler arasındaki kayalık yamaçları, kaya çatlaklarını, duvarları ve nehir yataklarını tercih eder. Akd. El. (Fig. 41)

Marrubium lutescens Boiss. \& Heldr. subsp. micranthum (Boiss. \& Heldr.) P. H. Davis (Akderme) (Türkiye endemiği)

Dik gövdeli, az dallı, 15-35 cm boyunda, yoğun beyaz yıldızsı tüylü, çok yıllık bitkiler. Alt yapraklar kaşıksıdan dairesele kadar değişen şekillerde. Gövde yaprakları ise dikdörtgenimsi eliptik. Korolla beyazımsı. Ülkemize özgü olan bu alt tür, sadece Antalya, Konya ve Mersin illerinde yayılış gösterir ve haziran-ağustos aylarında çiçeklenir. Yetişme ortamı olarak ise 1100-2300 mler arasındaki yamaçları ve kuru tarlaları tercih eder. Akd. El.

\section{Nepeta cadmea Boiss. (Honaz pisikotu) (Türkiye endemiği)}

Dik gövdeli, 30-120 cm boyunda, çok yıllık otsu bitkiler. Yapraklar yumurtamsıdan yumurtamsı-dikdörtgenimsiye kadar değişen şekillerde. Kaliks tüpsü, kıvrık. Korolla beyaz renkli. Fındıksı meyve dikdörtgenimsi. Ülkemize özgü olan bu tür, yetişme ortamı olarak 200-1900 m’ler arasındaki kayalık yamaçları, makiyi ve karaçam ormanlarını tercih eder. Çiçeklenme zamanı ise temmuz-ağustos aylarıdır. Akd. El. (Fig. 42)

Nepeta phyllochlamys P. H. Davis (Olimpos-Beydağları Milli Parkı endemiği) (Kaya pisikotu)

Çok yıllık bitkiler. Gövde kalkık uçlu, tüylü, (5-)15-25 cm boyunda. Yapraklar üçgenimsi-yumurtamsı, grimsi beyaz keçemsi tüylü. Kaliks tüpsü, yaklaşık $6.5 \mathrm{~mm}$ boyunda. Korolla'nın üst dudağı açık

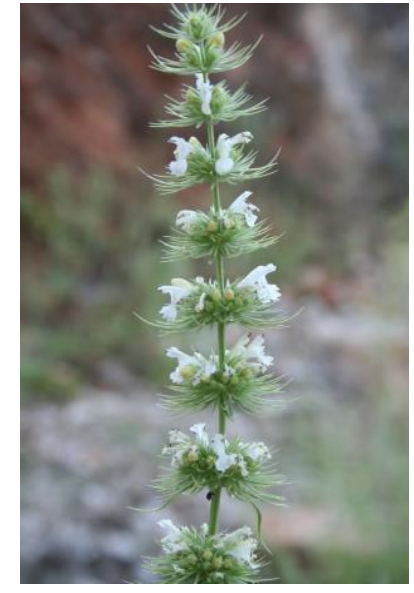

Fig. 42. Nepeta cadmea 
sarı, alt dudağı ise pembemsi-beyaz renkli, yaklaşık $10 \mathrm{~mm}$ boyunda. Fındıksı meyve dikdörtgenimsi. Olimpos-Beydağları Milli Parkına özgü olan bu tür, haziran-ağustos aylarında çiçek açar ve 60-2900 m’ler arasındaki kayalık yamaçlarda ve ormanlıklardaki kayalık yerlerde yetişir. Akd. El.

\section{Origanum solymicum P. H. Davis (Kuz mercanı)} (Olimpos-Beydağları Milli Parkı endemiği)

80 cm'ye kadar boylanabilen, tabanda sert tüylü bitkiler. Yapraklar kalpsiden yumurtamsıya kadar değişen şekillerde brakteler yumurtamsı. Kaliks 1dudaklı. Korolla pembe renkli. Sadece OlimposBeydağları Milli Parkına özgü olan bu tür, ağustos ayında çiçeklenir. Yetişme ortamı olarak 60-300 m’ler arasındaki kalkerli kayalıkları, yamaçları ve çam ormanlarını tercih eder. D. Akd. El. (Fig. 43)

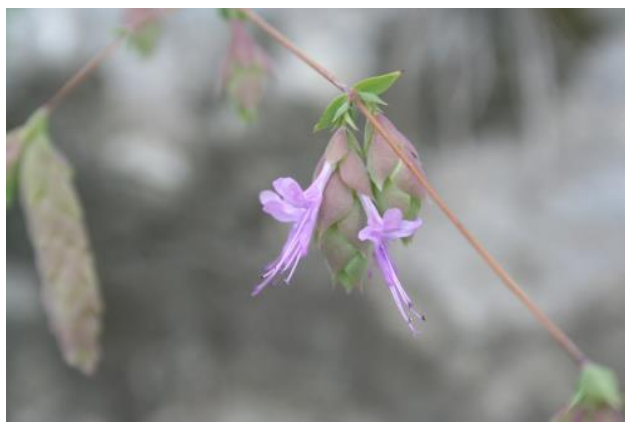

Fig. 43. Origanum solymicum

\section{Phlomis armeniaca Willd. (Boz Şavlak)}

60 cm'ye kadar boylanabilen otsu bitkiler. Alt yapraklar yumurtamsı-dikdörtgenimsi veya şeritsimızraksı. Üst yapraklar şeritsi-mızraksı. Çiçek durumları 4-10 çiçekli. Kaliks 13-17 mm boyunda. Korolla sarı renkli. Fındıksı meyveler çıplak. Haziran-ağustos aylarında çiçeklenen bu tür, yetişme ortamı olarak 800-2350 m’ler arasındaki yüksekliklerdeki çam ormanlarını, stebi, kuru kayalık yamaçları ve mısır tarlalarını tercih eder. Ir.-Tur. El.

\section{Phlomis bourgaei Boiss. (Çoban çırası)}

150 cm'ye kadar boylanabilen çalılar. Alt yapraklar üçgenimsi-yumurtamsıdan dikdörtgenimsimızraksıya kadar değişen şekillerde, tabanda kalpsi. Çiçek durumları (6-)12-20 çiçekli. Kaliks 17$20 \mathrm{~mm}$ boyunda. Korolla sarı renkli. Fındıksı meyve çıplak. Yetişme ortamı olarak deniz seviyesinden 1000 m'ye kadar olan makilikleri, meşe çalılıklarını, çam ormanlarını, kalkerli ve serpantin kayalıkları tercih etmekte olan bu tür, nisan-ağustos aylarında çiçeklenir. D. Akd. El.

\section{Salvia aethiopis L. (Habeş adaçayı)}

Dik gövdeli, 25-60 cm boyunda, iki veya çok yıllık otsu bitkiler. Yapraklar basit, çoğunlukla tabanda, yumurtamsı-eliptik veya dikdörtgenimsi. Çiçek durumları 4-6 çiçekli. Kaliks tüpsüyumurtamsı, $12 \mathrm{~mm}$ boyunda. Korolla beyaz renkli. Fındıksı meyve yumurtamsı. Yetişme ortamı olarak deniz seviyesinden 2100 m'ye kadar olan yüksekliklerdeki stebi, kireç taşı yamaçları, yol kenarlarını ve tarlaları tercih eden bu tür, mayısağustos aylarında çiçeklenir. ÇBFCB.

\section{Salvia caespitosa Montbret \& Aucher ex Benth.}

(Kırk Şalba) (Türkiye endemiği)

$60 \mathrm{~cm}$ çapına kadar genişleyen, tabanda odunsu, cüce çok yıllık bitkiler. Yapraklar pinnat parçalı, dış parçalar ters yumurtamsı, uçtaki parçalar ise yumurtamsı. Çiçek durumları 2-6 çiçekli. Kaliks çansı, mor renkli. Korolla menekşemsi mavi ile leylak pembe'ye kadar değişen renklerde, nadiren beyaz renkli. Meyve fındıksı. Ülkemize özgü olan bu tür, mayıs-

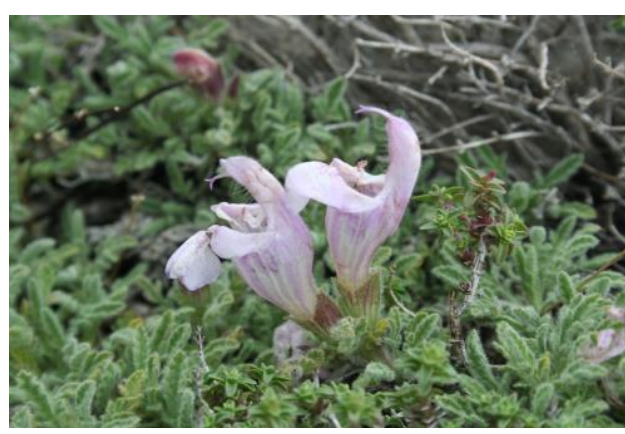

Fig. 44. Salvia caespitosa temmuz aylarında çiçeklenir. Yetişme ortamı olarak 1400-2400 m’ler arasındaki kayalık kireç taşı kayalıklarını ve kaya üzerlerini tercih eder. Ir.-Tur. El. (Fig. 44) 
Salvia verbenaca L. (Elmakekiği)

Dik gövdeli, 10-30(-70) cm boyunda çok yıllık otsu bitkiler. Yapraklar çoğunlukla tabanda, dar dikdörtgenimsiden yumurtamsıya kadar değişen şekillerde. Çiçek durumları 4-6 çiçekli. Kaliks çansı, 5-7 mm boyunda. Korolla leylaktan mora kadar değişen renklerde. Meyve fındıksı. Martmayıs aylarında çiçeklenen bu tür, yetişme ortamı olarak deniz seviyesinden 900 m'ye kadar olan yüksekliklerdeki meşe makiliklerini, yaprak döken ormanlıkları, yol ve tarla kenarlarını tercih eder. Akd. El.

\section{Scutellaria orientalis L. subsp. pinnatifida J. R. Edm. (Kırbaç sırımı)}

14 cm'ye kadar boylanabilen yatık gövdeli, tabanda odunsu gövdeli çok yıllık bitkiler. Yaprak laminası eliptik-yumurtamsıdan darca üçgenimsi-yumurtamsıya kadar değişen şekillerde. Kaliks iki dudaklı. Korolla oraksı, sarı renkli. Fındıksı meyve dikdörtgenimsi. Ülkemizde 15 alt tür ile temsil edilen bu bitki haziran-ağustos aylarında çiçeklenir. Yetişme ortamı olarak ise 1000-2440 m'ler arasındaki dağ stebini ve meşe açıklıklarını tercih eder. ÇBFCB. (Fig. 45)

Sideritis montana L. subsp. remota (d'Urv.) P. W.

Ball (Mor karaçay)

Yoğun uzun tüylü, basit veya tabanda dallı, 5-40 cm boyunda, bir yıllık otsu bitkiler. Yapraklar dikdörtgenimsiden mızraksıya kadar değişen şekillerde veya şeritsi. Çiçek durumları 4-6 çiçekli. Kaliks 6-10 mm boyunda. Korolla sarı renkli, daha sonra kahveren-

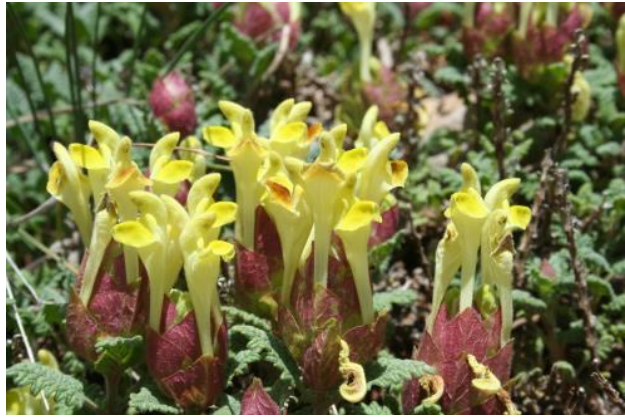

Fig. 45. Scutellaria orientalis subsp. pinnatifida

giye döner. Fındıksı meyve yumurtamsı. Bu alt tür, mayıs-ağustos aylarında çiçek açmakta olup, yetişme ortamı olarak ise deniz seviyesinden 2000 m’ye kadar olan yüksekliklerdeki kültür alanlarını, stebi ve meşe çalııklarını tercih eder. D. Akd. El.

\section{Sideritis stricta Boiss. \& Heldr. (Tilkikuyruğu çayı) (Türkiye endemiği)}

55-65 cm boyunda çok yıllık bitkiler. Gövde basit, yeşil veya sarımsı ve tüylü. Alt yapraklar şeritsimızraksıdan mızraksıya kadar değişen şekillerde, ipeksi tüylü veya çıplak. Çiçek durumları 10-18 tane, sık ve 4-6 çiçekli. Ortadaki brakteler dairesel-kalpsiden böbreksiye kadar değişir, 3-4.5 mm boyunda silli. Kaliks 10-11 mm boyunda. Korolla sarı renkli, 12-15 mm boyunda, iç kısımda kahve renkli çizgili. Mayıs-ağustos aylarında çiçeklenen bu adaçayı, ülkemize özgü olup sadece Antalya ve Muğla illerinde yayılış göstermektedir. Bu tür, 915 m’ye kadar olan yüksekliklerdeki meşe makiliklerinde ve deniz kenarındaki kayalık yamaçlarda yetişir. D. Akd. El. (Fig. 46)

\section{Stachys annua (L.) L. subsp. annua var. annua (Hacı osmanotu)}

íki veya çok yıllık yarı çalımsı bitkiler. Gövde yaprakları yumurtamsıdikdörtgenimsi veya genişçe mıraksıdan ters mızraksıya kadar değişen şekillerde. Çiçek durumları 4-8 çiçekli. Kaliks 10-11 mm boyunda. Korolla kremsi-sarı renkli. Fındıksı meyve ters yumurtamsı. Bu varyete, yetişme ortamı olarak 90-220 m'ler arasındaki yüksekliklerdeki güneşli kuru yamaçları, karışık ormanı ve tarlaları tercih eder. Çiçeklenme zamanı ise mart-eylül aylarıdır. ÇBFCB.

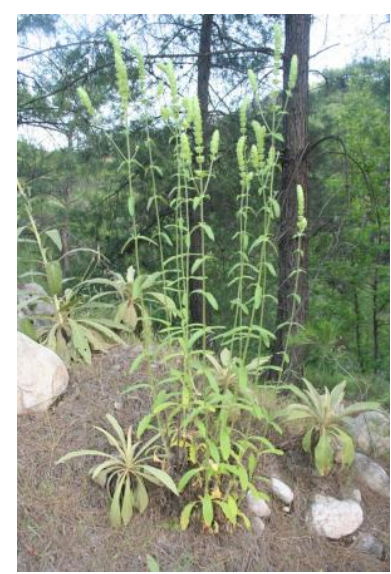

Fig. 46. Sideritis stricta 
Stachys cretica L. subsp. anatolica Rech. fil. (Yağlıkara) (Türkiye endemiği)

Dik gövdeli, basit veya dallı, 1 m'ye kadar boylanabilen çok yıllık otlar. Alt yapraklar dikdörtgenimsi-kaşıksı. Çiçek durumları 10-16 çiçekli. Kaliks 8-11 mm boyunda. Korolla gül-pembe renkli. Fındıksı meyve ters yumurtamsı. Ülkemize özgü olan bu alt tür, mayıs-eylül aylarında çiçeklenir. Yetişme ortamı olarak ise 100-2900 m'ler arasındaki kireçtaşı kayalık yamaçlarını, stebi ve düz çayırlıkları tercih eder. ÇBFCB.

\section{Teucrium chamaedrys L. subsp. syspirense (K. Koch) Rech. f. (Sıcakotu)}

Rizomlu, 5-50 cm boyunda, yarı çalımsı çok yıllık otsu bitkiler. Yapraklar dikdörtgenimsi veya ters yumurtamsı-dikdörtgenimsi, genellikle kenarları dişli. Çiçek durumları (2-)4-8 çiçekli. Kaliks tüpsü-çansı. Korolla kırmızımsı-mor renkli. Fındıksı meyve düz veya buruşuk. Haziran-ağustos aylarında çiçeklenen bu alt tür, yetişme ortamı olarak 90-2430 m’ler arasındaki kireçtaşı kayalıkları ve stebi tercih eder. Ir.-Tur. El.

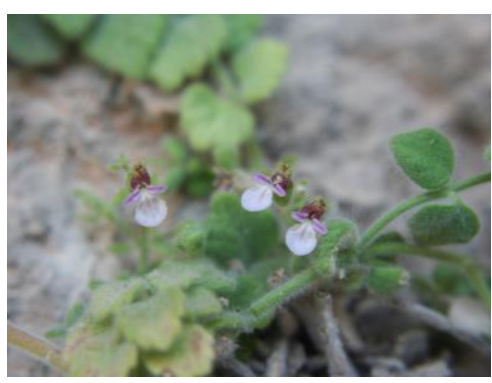

Fig. 47. Teucrium odontites

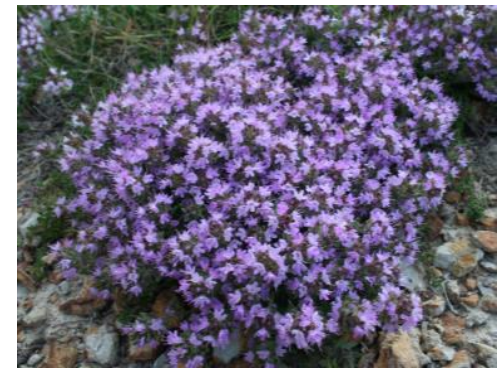

Fig. 48. Thymus cilicicus



Fig. 49. Lythrum junceum

\section{Teucrium odontites Boiss. \& Balansa (Hamesi) (Türkiye endemiği)}

10-15 cm boyunda, yatık gövdeli, çok yıllık otsu bitkiler. Yapraklar yumurtamsı-dairesel. Kaliks 4 mm boyunda. Korolla mor renkli. Fındıksı meyve düz veya buruşuk. Bu tür ülkemize özgü olup Antalya, Muğla ve Mersin illerinde yayılış göstermektedir. Haziran ayında çiçeklenen bitki, yetişme ortamı olarak deniz kenarına yakın dikey kayalık yarıklarını tercih eder. Akd. El. (Fig. 47)

\section{Thymus cilicicus Boiss. \& Bal. (Kılçık kekiği)}

3-15 cm boyunda, çalı benzeri çok yıllık bitkiler. Yapraklar mızraksı-biz biçiminde. Kaliks 3.5-5 $\mathrm{mm}$ boyunda. Korolla leylak-mor renkli. Meyve fındıksı. Bu kekik türü nisan-ağustos aylarında çiçeklenmekte olup yetişme ortamı olarak 70-2000 m’ler arasındaki kayalık açıkıkları tercih eder. D. Akd. El. (Fig. 48)

\section{Thymus sipyleus Boiss. (Sipil kekiği)}

Yoğun yastık oluşturan, odunlu bitkiler. Çiçekli gövde 1-7(-10) cm, dik ve tüylü. Gövde yaprakları yumurtamsı-eliptik veya yumurtamsı-mızraksı. Kaliks çan şeklinde. Korolla beyaz, nadiren pembe. Meyve fındıksı. Mayıs-ağustos aylarında çiçeklenen bu kekik, yetişme ortamı olarak 4002700 m yüksekliklerdeki dağılk stepleri ve kayalık yamaçları tercih eder. ÇBFCB.

Familya: Linaceae (Ketengiller)

\section{Linum usitatissimum L. (Keten)}

10-100 cm boyunda, dik gövdeli, bir veya iki yıllık otsu bitkiler. Yapraklar şeritsi veya şeritsimızraksı. Pedisel dik. Sepaller genişçe eliptik-yumurtamsı. Petaller mavi renkli, 10-15 mm boyunda. Kapsül meyve 7-8 mm boyunda. Nisan ayında çiçeklenen bu türün kültürü yapılmaktadır. ÇBFCB.

\section{Familya: Lythraceae (Aklarotugiller)}


Lythrum junceum Banks \& Sol. (Sivriaklarotu)

Narin yapılı, çıplak çok yıllık otsu bitkiler. Gövde $20-60 \mathrm{~cm}$ boyunda ve kalkık uçlu. Yapraklar geniş̧̧e dikdörtgenimsiden darca eliptiğe kadar değişen şekillerde. Petaller 5-6 mm boyunda pembemsi-leylaktan mor'a kadar değişen renklerde. Meyve kapsül. Yetişme ortamı olarak deniz seviyesinden 1750 m'ye kadar olan yüksekliklerdeki bataklık ve ırmak kenarlarını tercih eder. Çiçeklenme zamanı ise nisan-temmuz aylarıdır. Akd. El. (Fig. 49)

\section{Familya: Malvaceae (Ebegümecigiller)}

\section{Althaea officinalis L. (Deli hatmi)}

2 m’ye kadar boylanabilen yumuşak yıldızsı tüylü, çok yıllık otsu bitkiler. Yapraklar üçgenimsi veya kamamsı-üçgenimsi, basit veya çok zayıf 3-loplu. Epikaliks segmentleri 6-9 adet. Petaller 9$14 \mathrm{~mm}$ boyunda, beyazdan pembemsi-beyaza kadar değişen renklerde. Merikarp meyve buruşuk, yıldızsı tüylü. Yetişme ortamı olarak deniz seviyesinden 1250 m'ye kadar olan yüksekliklerdeki batakıı alanları, kanalları ve tarla kenarlarını tercih etmektedir. Çiçeklenme zamanı ise haziran-ağustos aylarıdır. ÇBFCB.

\section{Corchorus olitorius L. (Mühliye)}

0.5-2 m boyunda bir yıllık otsu bitkiler. Yapraklar yumurtamsı veya mızraksı, testere dişli kenarlı. Çiçekler yaprak koltuklarında, 1-2 tane, sarı veya beyaz renkli. Sepal ve petal 5 adet. Kapsül meyve uzamış, silindirik, 10 açılı. Adana ve çevresinde kültür yapılan bu tür, ağustos ve eylül aylarında çiçeklenir. ÇBFCB. (Fig. 50)

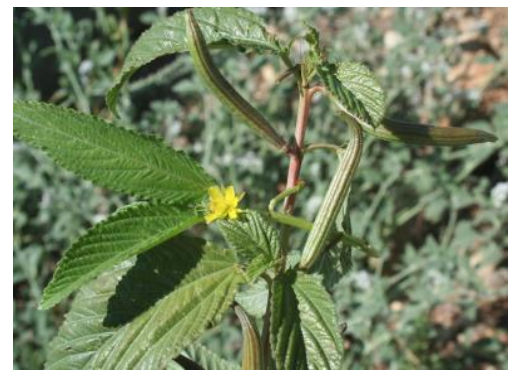

Fig. 50. Corchorus olitorius

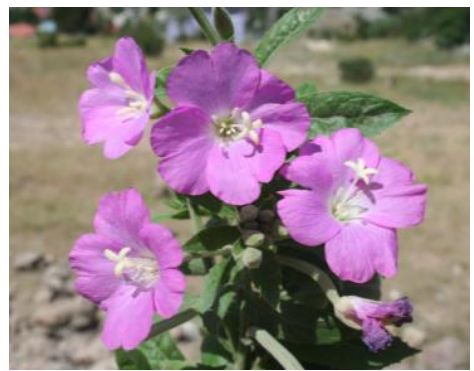

Fig. 51. Epilobium hirsutum



Fig. 52. Bartsia trixago

\section{Moraceae (Dutgiller)}

\section{Ficus carica L. subsp. carica (Incir)}

10 m’ye kadar boylanabilen ağaçlar veya çalılar. Yapraklar dökülücü, tam kenarlı veya 3-5 loplu. Meyve tek, sarımsı, yeşilimsi veya menekşemsi renkli. Bu tür ülkemizde iki alt tür ile temsil edilmektedir. Mart ve nisan aylarında çiçeklenen bu alt türün ülkemizde kültürü de yapılmaktadır. Yetişme ortamı olarak ise 10-1770 m'ler arasındaki karışık ormanları ve taşlık alanları tercih eder. Akd. El.

\section{Familya: Onagraceae (Yakıotugiller)}

\section{Epilobium hirsutum L. (Hasanhüseyin çiçeği)}

Çok dallı, dik, çok yıllık bitkiler. Gövde yoğun uzun tüylü, kalın rizomlu ve 30-210 cm boyunda. Yapraklar mızraksıdan dikdörtgenimsiye kadar değişen şekillerde. Petaller pembemsi-mor renkli. Kapsül meyve 4-10 cm boyunda. Temmuz-eylül aylarında çiçeklenen bu tür, yetişme ortamı olarak deniz seviyesinden 500 m'ye kadar olan yüksekliklerdeki bataklıkları ve dere yataklarını tercih eder. ÇBFCB. (Fig. 51)

\section{Familya: Orobanchaceae (Canavarotugiller)}


Bartsia trixago L. (Karaballıbaba)

Alt kısımda salgısız, üst kısımda salgılı tüylü, bir yıllık bitkiler. Gövde dik, basit, $10-70 \mathrm{~cm}$ boyunda. Yapraklar şeritsiden şeritsi-dikdörtgenimsiye kadar değişen şekillerde. Brakteler kalpsi. Kaliks 10-12 mm boyunda. Korolla beyaz, üst kısımda pembe renkli. Kapsül meyve yumurtamsıküresel. Ülkemizde geniş bir yayılış alanına sahip olan bu tür, mart-haziran aylarında çiçeklenir. Yetişme ortamı olarak deniz seviyesinden 300 m'ye kadar olan yüksekliklerdeki friganayı, kumulları, kireç taşılı alanları ve mısır tarlalarını tercih eder. ÇBFCB. (Fig. 52)

\section{Orobanche minor Sm. (Güveotu)}

10-50 cm boyunda parazit bitkiler. Brakteler genellikle çiçeklerle eşit boyda. Kaliks yarıya kadar bölünmemiş veya iki dişli. Korolla 10-18 mm boyunda, sarımsı-beyaz, üst dudaklar menekşe veya mavi renkli, silindirik, kırmııımsı. Meyve kapsül. Ülkemizde oldukça geniş bir yayılış alanına sahip olan bu tür, nisan-haziran aylarında çiçeklenir. Baklagiller üzerinde parazit olan bu bitki, 2000 m’ye kadar olan yüksekliklerde yetişir. ÇBFCB.

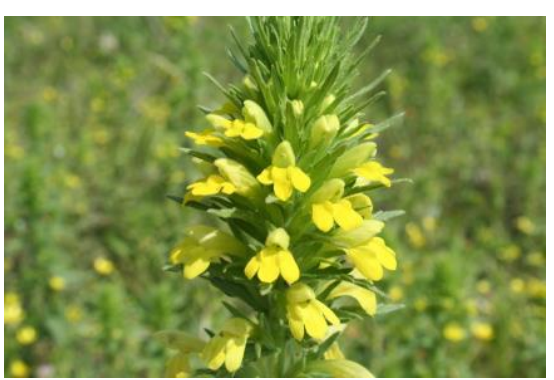

Fig. 53. Parentucellia viscosa

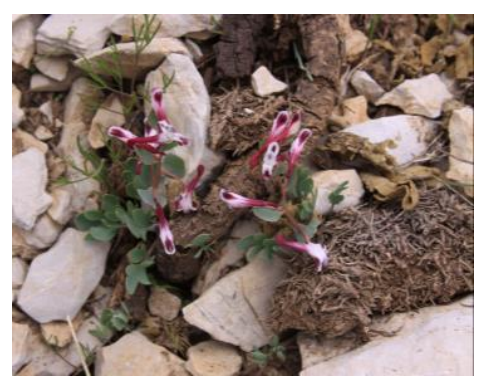

Fig. 54. Corydalis wendelboi subsp. wendelboi

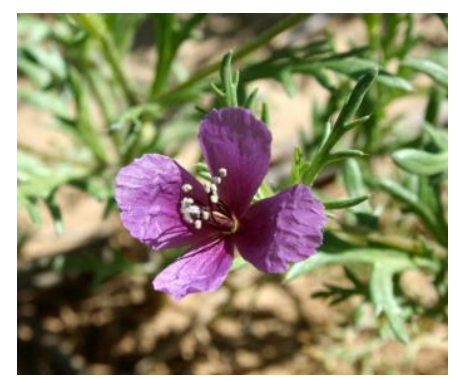

Fig. 55. Roemeria hybrida subsp. hybrida

\section{Parentucellia viscosa (L.) Caruel (Salgılı üçdiliotu)}

Salgılı tüylü, bir yıllık otsu bitkiler. Gövde dik ve (10-)20-50 cm boyunda. Yapraklar dikdörtgenimsi-mızraksı, dişil kenarlı. Kaliks tüpsü. Korolla sarı veya sarımsı-beyaz renkli. Kapsül meyve 9-12 mm boyunda. Ülkemizde Ege, Karadeniz ve Akdeniz Bölgeleri'nde yayılış gösteren bu tür, nisantemmuz ayında çiçeklenir. Yetişme ortamı olarak ise deniz seviyesinden 1400 m'ye kadar olan yüksekliklerdeki çayırlıkları, nemli yerleri kum tepelerini ve meşe çalııklarını tercih eder. Akd. El. (Fig. 53)

\section{Familya: Oxalidaceae (Ekşiyoncagiller)}

\section{Oxalis corniculata L. (Sarı ekşiyonca)}

Bir veya çok yıllık otsu bitkiler. Gövde çok sayıda, yatık. Yapraklar üç yaprakçıkı; yaprakçıklar ters kalpsi. Sepaller mızraksı, 3-5 mm boyunda. Petaller soluk sarı renkli. Kapsül meyve dikdörtgenimsi silindirik. 1000 m'ye kadar olan yüksekliklerdeki açık alanlarda yetişen bu tür, martağustos ayında çiçeklenir. ÇBFCB.

\section{Familya: Papaveraceae (Haşhaşgiller)}

\section{Corydalis wendelboi Liden subsp. wendelboi (Tarla kuşu) (Türkiye endemiği)}

Yumrulu bitkiler. Gövde yükselici-dik, 7-18 cm boyunda. Gövde yaprakları sarmal, 2-ternat; segmentler yumurtamsıdan dikdörtgenimsiye kadar değişen şekillerde. Çiçek durumu seyrek. Çiçekler pembe, koyu kırmızı veya mavimsi pembe renkli. Kapsül meyve dikdörtgenimsi-mızraksı. Ülkemize özgü olan bu alt tür, 1000-2100 m’ler arasındaki taşlı yamaçlarda yetişir. Çiçeklenme zamanı ise nisan-temmuz aylarıdır. ÇBFCB. (Fig. 54)

Fumaria officinalis L. subsp. officinalis (Şahtere) 
Sağlam yapılı otsu bitkiler. Yapraklar pinnatisekt. Çiçek durumu sık (10-)20-40 çiçekli. Brakteler şeritsi-mızraksı. Sepaller mızraksı. Korolla pembe renkli. Meyve 1 tohumlu fındık. Nisan ve mayıs aylarında çiçeklenen bu alt tür, 700 m’ye kadar olan yüksekliklerdeki kültür alanlarını ve kayalık yerleri tercih eder. ÇBFCB.

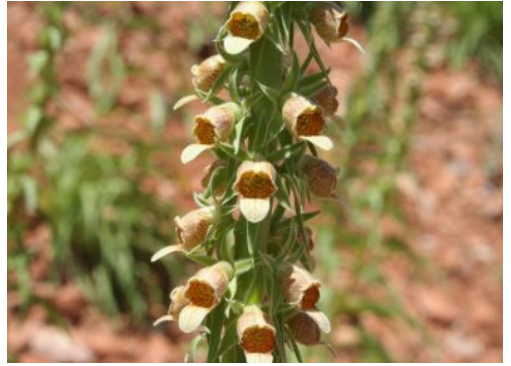

Fig. 56. Digitalis cariensis

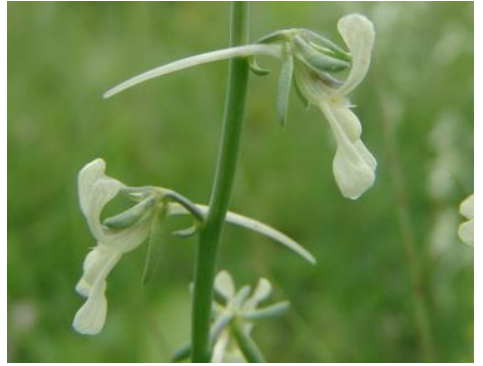

Fig. 57. Linaria chalepensis var. brevicalyx



Fig. 58. Veronica lycica

Roemeria hybrida (L.) DC. subsp. hybrida (PItpıtotu)

Narin yapılı, 50 cm'ye kadar boylanabilen bir yıllık otsu bitkiler. Yapraklar 2-3 pinnatisekt parçalı, segmentler şeritsi. Çiçekler tek ve gösterişli ve menekşe renkli. Kapsül meyve şeritsi-silindirik. Nisan-haziran ayında çiçeklenen bu alt tür, yetişme ortamı olarak deniz seviyesinden 1400 m'ye kadar olan yüksekliklerdeki tahrip edilmiş alanları, tarlaları ve üzüm bağlarını tercih eder. ÇBFCB. (Fig. 55)

\section{Familya: Plantaginaceae (Sinirotugiller)}

Digitalis cariensis Boiss. ex Benth. (İshal otu)

Narin yapılı, kümeli çok yıllık otsu bitkiler. Gövde çok sayıda, 30-80 cm boyunda. Gövde yaprakları şeritsi. Korolla 10-15 mm boyunda, tüp kısmı açık sarımsı kahve renkli, alt loplar beyazımsı. Kapsül meyve 9-10 mm uzunluğunda. Bu tür, Konya, Isparta, Antalya ve Muğla illerinde yayılış gösterir. Haziran-temmuz aylarında çiçeklenen ishal otu, 800-1700 m’ler arasındaki kayalık yamaçları, ormanlık ve makilik alanları tercih eder. D. Akd. El. (Fig. 56)

\section{Globularia davisiana L. (Has küreçiçeği) (Olimpos-Beydağları Milli Parkı endemiği)}

$20(-100)$ cm'ye kadar boylanabilen çalılar. Taban yaprakları belirsiz. Gövde yaprakları çok sayıda yarı daireselden eliptiğe veya genişçe yumurtamsıya kadar değişen şekillerde. Kapitula yumurtamsı-yarısilindirik. Korolla mavi renkli. Olimpos-Beydağları Milli Parkı'na özgü olan bu tür, ağustos ayında çiçeklenir ve dikey kireç taşlı sarp kayalıkların üzerinde veya altında yetişir. D. Akd. El.

\section{Linaria chalepensis (L.) Mill. var. brevicalyx P. H. Davis (Halep nevruzotu) (Antalya endemiği)}

Narin yapılı, dik, 12-40 cm boyunda, bir yıllık otlar. Yapraklar şeritsi veya yarı şeritsi-mızraksı. Çiçek durumu seyrek. Korolla beyaz renkli. Fındıksı meyve yarı dairesel. Antalya iline özgü olan bu varyete, nisan ve mayıs aylarında çiçeklenir. Yetişme ortamı olarak ise 100-150 m'ler arasındaki kireç taşı kayalıkları tercih eder. D. Akd. El. (Fig. 57)

\section{Plantago lagopus L. (Kırk damarotu)}

5-45 cm boyunda, çok yıllık nadiren bir yıllık otsu bitkiler. Yapraklar mızraksı-yumurtamsı, mıraksı veya dar mızraksı. Başak çiçek durumu silindirik, yumurtamsı veya yumurtamsı-küresel. Korolla lopları üçgenimsi-yumurtamsı. Kapsül meyve elipsoid. Ülkemizde geniş bir yayılış alanına sahip olan bu tür, nisan-ağustos aylarında çiçeklenir. Yetişme ortamı olarak ise deniz seviyesinden 600 m'ye kadar olan yüksekliklerdeki yol kenarlarını, tarla kenarlarını, taşlı tepelikleri, 
kayalık yerleri, çayırlıkları ve kumul plajları tercih eder. Akd. El.

Veronica cuneifolia D. Don subsp. cuneifolia (Yer mavişi) (Türkiye endemiği)

1-7 cm boyunda, kalkık uçlu, tabanda odunlu çok yıllık bitkiler. Yapraklar daireselden eliptiğe kadar değişen şekillerde. Kaliks 2-5 mm boyunda. Korolla mavi veya mor renkli. Kapsül yarı dairesel. Ülkemize özgü olan bu alt tür, nisan-ağustos aylarında çiçeklenir. Yetişme ortamı olarak 1100-2200 m’ler arasındaki yüksekliklerdeki karaçam açıklıkları, ardıç çalııkları, kayalık yamaçları tercih eder. ÇBFCB.

\section{Veronica lycica E. Lehm. (Fethiye mavişi) (Türkiye endemiği)}

Bir yıllık otsu bitkiler. Gövde yatık veya eğik yükselişli. Yapraklar yarı üçgenimsi, tabanda kamamsı. Korolla beyaz, merkezde sarı renkli. Meyve kapsül. Ülkemize özgü olan bu Fethiye mavişi, Muğla ve Antalya illerinde yayılış gösterir. Mart-temmuz aylarında çiçeklenen bu bitki yetişme ortamı olarak deniz seviyesinden 1800 m'ye kadar olan yüksekliklerdeki sedir ormanlarını ve kireçtaşı kayalıklarını tercih eder. Akd. El. (Fig. 58)

Familya: Plumbaginaceae (Kardikenigiller)

Acantholimon ulicinum (Willd. ex Schultes) Boiss. var. ulicinum (Kardikeni)

Oldukça yoğun çalımsı bitkiler. Yapraklar şeritsiüçgenimsi. Çiçek kümesi sapı çok kısa. Kaliks tüpü tüylü, beyaz veya mor renkli. Petaller parlak pembe renkli. 1200-3000 m'ler arasındaki taşlı yamaçlarda, kireç taşlı ve serpantin kayalıklarda ve dağların en süt kısımlarında yetişen bu bitki, haziran-ağustos aylarında çiçek açar. D. Akd. El. (Fig. 59)

\section{Familya: Polygonaceae (Madımakgiller)}

Polygonum cognatum Meissn. (Madımak)

Yatık gövdeli, çok yıllık otsu bitkiler. Boğum kını belirgin, üç damarlı. Yapraklar dikdörtgenimsi-eliptik. Çiçekler yaprak kenarlarında kümelenmiş. Periyant pembemsi beyaz renkli. Meyve fındıksı. Mayıs-eylül

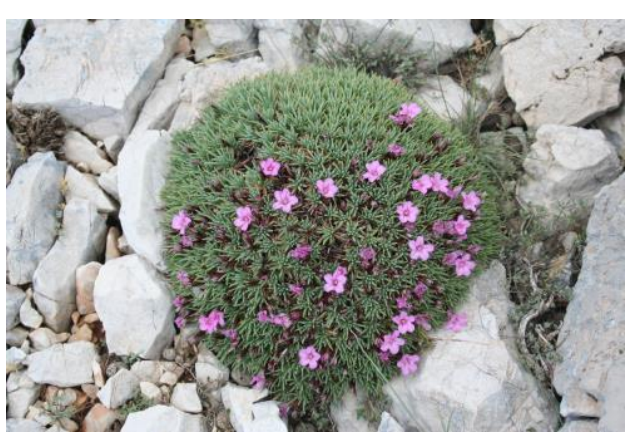

Fig. 59. Acantholimon ulicinum var. ulicinum



Fig. 60. Cyclamen coum subsp. coum aylarında çiçeklenen bu tür, 720-3000 m’ler arasındaki yüksekliklerdeki yol kenarlarında, yamaçlarda ve kültür alanlarında yetişir. ÇBFCB.

\section{Polygonum salicifolium Brouss. ex Willd. (Bibercik)}

Eğik tırmanışlı, dallı çok yıllık otsu bitkiler. Boğum kını kahve renkli. Yapraklar mızraksı, kısa saplı. Çiçek durumu seyrek bir başak. Çiçekler beyazdan pembeye kadar değişir. Meyve fındıksı ve kahverenkli. Bataklık kenarlarında yetişen bu tür, ağustos ve eylül aylarında çiçeklenir. ÇBFCB.

\section{Familya: Primulaceae (Çuhaçiçeğigiller)}

\section{Androsace maxima L. (Tavukkursağı)}

Dik gövdeli, 1-15 cm boyunda bir yıllık otsu bitkiler. Yapraklar eliptikten geniş̧̧e yumurtamsıya kadar değişen şekillerde. Kaliks 4-14 mm boyunda. Korolla, kaliksin içinde, beyazdan pembeye kadar değişen renklerde. Kapsül meyve 2-6 mm boyunda. Ülkemizde geniş bir yayılış alanına sahip olan bu tür, nisan ve mayıs ayında çiçeklenir. Yetişme ortamı olarak ise 300-1850 m'ler arasındaki kireç taşlı kayalıkları, çam ormanı açıklıkları, kültür alanları ve tarlaları tercih eder. ÇBFCB. 


\section{Cyclamen coum Miller subsp. coum (Yersomunu)}

3-5 cm çapında yumrulu bitkiler. Yapraklar dairesel veya yarı dairesel. Korolla açık veya koyu kırmızı, pembe veya nadiren beyaz renkli; lopları kısa, küt ve genellikle 10 mm'den kısa. Meyve kapsül. Şubat-mayıs aylarında çiçeklenen bu alt tür, 2135 m’ye kadar olarak yüksekliklerdeki kızılçam ormanlarında, karışık ormanlarda ve kayalık tepeliklerdeki çalııklar altında yetişir. ÇBFCB. (Fig. 60)

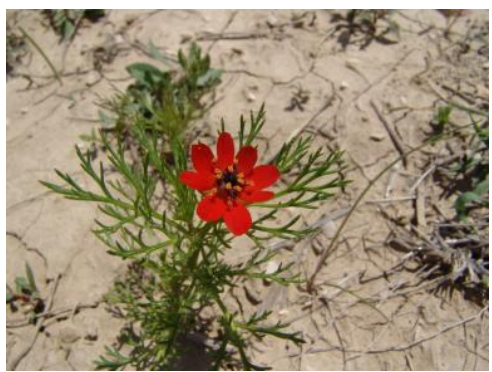

Fig. 61. Adonis annua

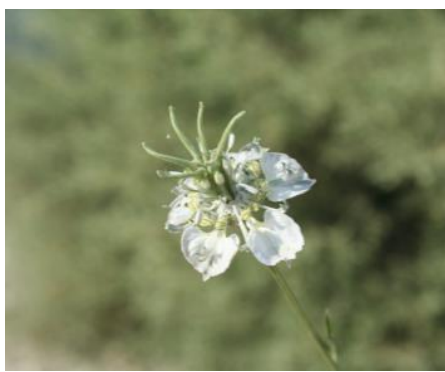

Fig. 62. Nigella arvensis var. glauca Fig. 63. Cerasus prostrata var. glabrifolia

Familya: Ranunculaceae (Düğünçiçeğigiller)

\section{Adonis annua L. (Kanavcıotu)}

10-30 cm boyunda, tüysüz, bir yıllık otsu bitkiler. Yaprak kenarındaki yırtıklar şeritsi. Çiçekler 15$22 \mathrm{~mm}$ çapında. Sepaller morumsu renkli. Petaller koyu kırmızı renkli. Aken meyve 3-3.5 mm boyunda. Bu tür, yetişme ortamı olarak deniz seviyesinden 500 m'ye kadar olan yüksekliklerdeki tarlaları tercih eder. Çiçeklenme zamanı ise nisan-haziran aylarıdır. Akd. El. (Fig. 61)

Nigella arvensis L. var. glauca Boiss. (Tarla çörekotu)

10-50 cm boyunda, genellikle dallı bir yıllık otsu bitkiler. Gövde yaprakları pinnatisekt, üç parçalı veya tam kenarlı. Sepaller soluk mavi, grimsi veya beyaza renkli, yumurtamsı. Petaller alt kısımda iki parçalı. Folikül meyve dikdörtgenimsi. Ülkemizde geniş bir yayılış alanına sahip olan bu varyete, yetişme ortamı olarak deniz seviyesinden 1700 m'ye kadar olan yüksekliklerdeki stebi, nemli yerleri ve tarlaları tercih eder. Çiçeklenme zamanı ise haziran-ağustos aylarıdır. ÇBFCB. (Fig. 62)

\section{Ranunculus ficaria L. subsp. ficariiformis Rouy \& Foucaud (Arpacık salebi)}

10-20 cm boyunda çok yıllık otsu bitkiler. Yapraklar yumurtamsı-dairesel veya yumurtamsıüçgensi, tabanda kalpsi. Petaller sarı renkli, 15-20 mm boyunda. Bu alt tür, yetişme ortamı olarak deniz seviyesinden 800 m'ye kadar olan yüksekliklerdeki nemli yerleri, tarla kenarlarını ve tepelikleri tercih eder. Çiçeklenme zamanı ise mart ve nisan aylarıdır. ÇBFCB.

\section{Familya: Rhamnaceae (Cehrigiller)}

\section{Rhamnus thymifolia Bornm. (Pala cehri) (Türkiye endemiği)}

Sürünücü ve dik gövdeli, 2 m’ye kadar boylanabilen çalılar. Yapraklar otsu, dar eliptik-ters yumurtamsıdan genişçe ters yumurtamsıya kadar değişen şekillerde. Eriksi meyve 4-6 mm çapında, siyah, kırmızı veya sarımsı renkli. Ülkemize özgü olan bu tür, yetişme ortamı olarak 201200 m'ler arasındaki makilikleri ve kireç taşlı kayalık yerleri tercih eder. Çiçeklenme zamanı ise nisan(-mayıs) ayıdır. ÇBFCB.

\section{Familya: Rosaceae (Gülgiller)}

Cerasus prostrata (Labill.) Ser. var. glabrifolia (Moris) Browicz (Taş kirazı)

Yatık gövdeli ya da yastık şeklinde, dikensiz, 1 m’ye kadar boylanabilen çalılar. Yapraklar genişçe 
yumurtamsıdan eliptik-ters yumurtamsıya kadar değişen şekillerde, her iki tarafta da hemen hemen çıplak. Petaller kırmızımsı-pembe renkli. Ülkemizde sadece Antalya-Kemer'de, ülkemiz dışında ise Suriye'de yetişen bu varyete, nisan-haziran aylarında çiçeklenir. Yetişme ortamı olarak ise 2200 m'lerdeki kayalık yerleri tercih eder. Akd. El. (Fig. 63)

Rosa pulverulenta M. Bieb. (Bodur gül)

Dikenli, 0.1-0.58(-1) m boyunda çalılar. Yapraklar küçük, 5 yaprakçıklı; yaprakçıklar yumurtamsı, eliptik veya yarı dairesel. Petaller pembe renkli. Çukur çiçek tablası küreselden yumurtamsıya kadar değişen şekillerde, kırmızı renkli, dikenli. Haziran ve temmuz aylarında çiçeklenen bu tür, yetişme ortamı olarak 700-2550 m'ler arasındaki kuru açıklıkları, ardıç çalııklarını, kayalık yerleri ve subalpin çayırlıkları tercih eder. ÇBFCB.

\section{Sanguisorba verrucosa (G. Don) Ces. (Sincanotu)}

Dik gövdeli, (5-)10-75 cm boyunda çok yıllık otsu bitkiler. Yapraklar tabanda rozet şeklinde. Üst yapraklar birkaç tane. Kafa hemen hemen küresel. Sepaller yumurtamsı-dikdörtgenimsi, beyazımsı veya pembemsi kenarlı. Bu tür nisan-haziran aylarında çiçeklenir ve yetişme ortamı olarak deniz seviyesinden 1100 m'ye kadar olan yüksekliklerdeki nemli alanları, tarlaları ve yamaçları tercih eder. ÇBFCB.

\section{Familya: Rubiaceae (Kökboyagiller)}

\section{Crucianella latifolia L. (Geniş haçotu)}

30 cm'ye kadar boylanabilen bir yıllık otsu bitkiler. Yapraklar (4-)5-6'lı halkalarda, alttakiler ters yumurtamsı-eliptik, üsttekiler ise mızraksıdan şeritsiye kadar değişir. Çiçekler 4 parçalı. Korolla 5 $7.5 \mathrm{~cm}$ boyunda. Meyve kuru, çıplak; merikarp 2 adet, yumurtamsı. Ülkemizde geniş bir yayılış alanına sahip olan bu tür, nisan-ağustos ayında çiçeklenir. Yetişme ortamı olarak deniz seviyesinden 1250 m’ye kadar olan yüksekliklerdeki çam ormanı açıklıklarını, makilikleri, friganayı, kayalık yamaçları, üzüm bağlarını ve tarlaları tercih eder. Akd. El.

\section{Galium aparine L. (Çoban süzgeci)}

180 cm'ye kadar boylanabilen bir yıllık otsu bitkiler. Yapraklar halkasal, dar veya geniş tersmızraksı. Korolla beyazımsı. Merikarplar 3-5 mm, sert kıllı tüylü. Ülkemizde geniş bir yayılış alanına sahip olan bu tür, 30-1800 m’ler arasındaki nemli yerlerde, çalılarda ve kültür alanlarında yetişir. Çiçeklenme zamanı ise nisan-temmuz aylarıdır. ÇBFCB.

\section{Galium canum Req. ex DC. subsp. ovatum Ehrend. (Tavuk iplikçiği)}

Yarı-çalı, tabanda odunsu çok yıllık otsu bitkiler. Gövdeler (5-)10-25(-35) cm boyunda ve dallı. Yapraklar şeritsi-mızraksıdan yumurtamsıya kadar değişen şekillerde. Korolla mor, çok nadiren sarımsı. Merikarplar genişçe böbreksi, koyu kahve renkli ve tüylü. Ülkemizde Akdeniz ve Güneydoğu Anadolu Bölgeleri'nde yayılış gösteren bu alt tür, nisan-temmuz aylarında çiçeklenir. Yetişme ortamı olarak ise 10-1200 m'ler arasındaki güneşli kireç taşı kayalıkları ve duvarları tercih eder. D. Akd. El.

Galium floribundum Sm. subsp. airoides Hub.Mor. ex Ehrend. \& Schönb.-Tem. (Tekirova iplikçiği) (Türkiye endemiği)

Narin yapılı, dallanmıs, (4-)10-30 cm boyunda bir yıllık otsu bitkiler. Yapraklar şeritsi-ters mızraksı veya şeritsiden yarı ipliksiye kadar değişen şekillerde.

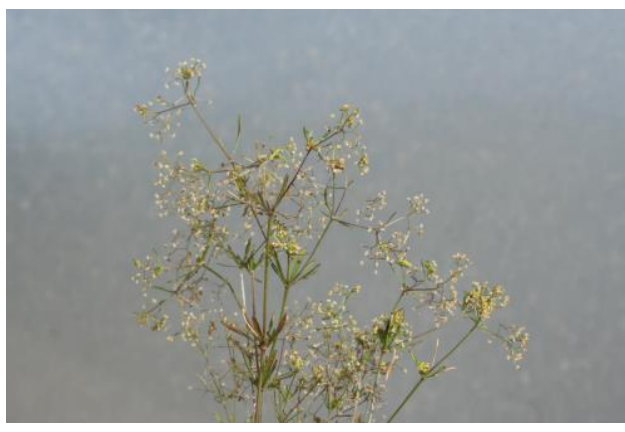

Fig. 64. Galium floribundum subsp. airoides 
Korolla morumsu-kahve renkli; loplar dikdörtgenimsi. Merikarp böbrek biçimli. 1950 yılında Tekirova'dan toplanarak 1979 yılında bilim dünyasına tanıtılan bu alt tür, ülkemize özgü olup, Antalya, Isparta ve Muğla illerinde yetişir. Mayıs-temmuz aylarında çiçeklenen bu bitki, kayalık yerler ve step tepeliklerinde yetişir. D. Akd. El. (Fig. 64)

\section{Familya: Scrophulariaceae (Sıracaotugiller)}

Verbascum cheiranthifolium Boiss. var. cheiranthifolium (Bozkulak) 30-120 cm boyunda, iki yıllık bitkiler. Taban yaprakları şeritsimızraksıdan dikdörtgenimsiye kadar değişen şekilde. Kaliks 2-3 mm boyunda. Korolla sarı renkli ve $20-25 \mathrm{~mm}$ çapında. Kapsül meyve silindirikten dikdörtgenimsi-eliptiğe kadar değişen şekillerde. Yetişme ortamı olarak 680-1930 m’ler arasındaki ormanlık alanları, meşelik çalııkları, stebi, çayırlıkları ve kireç taşlı kayalıkları tercih eder ve mayıs-ağustos aylarında çiçeklenir. ÇBFCB. (Fig. 65)

\section{Familya: Solanaceae (Patlıcangiller)}

Datura stramonium L. (Boru çiçeği)

40-200 cm boyunda, dallı, bir yıllık otsu bitkiler. Yapraklar saplı, yumurtamsı, dişli kenarlı. Kaliks 3-4 cm. Korolla beyaz, 5-9 cm boyunda. Kapsül meyve yumurtamsı ve dikenli. Ülkemizde geniş bir

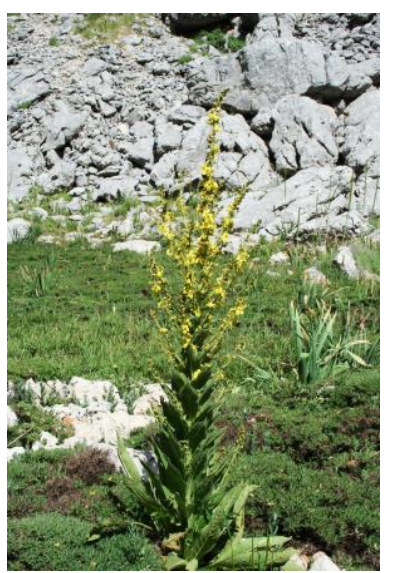

Fig. 65. Verbascum cheiranthifolium var. cheiranthifolium yayılış alanına sahip olan bu tür, mayıs-kasım ayında çiçeklenir. Yetişme ortamı olarak ise 950 m'ye kadar olan yüksekliklerdeki tarlaları, nemli yerleri ve yol kenarlarını tercih eder. ÇBFCB.

\section{Solanum decipiens Opiz (Ece avlusu)}

Dik gövdeli, 10-70 cm boyunda, dallı, bir yıllık otsu bitkiler. Yapraklar yumurtamsıdan yumurtamsı-açılıya kadar değişen şekillerde. Kaliks 2 mm boyunda. Korolla beyaz, 5-6 mm boyunda. Üzümsü meyve siyah ve küresel. Haziran-kasım aylarında çiçeklenen bu bitki yetişme ortamı olarak deniz seviyesinden 1500 m'ye kadar olan yüksekliklerdeki, nehir kenarlarını, yol kenarlarını ve kültür alanlarını tercih eder. ÇBFCB.

\section{Familya: Thymelaeaceae (Sıyırcıkgiller)}

Daphne oleoides Schreb. subsp. oleoides (Gövçek)

Dik, dallı, 15-60 cm boyunda çalılar. Yapraklar derimsi, ters yumurtamsı, ters mızraksı veya eliptik. Çiçekler sapsız, güzel kokulu. Periyant beyaz veya kremsi-beyaz; loplar dar üçgenimsi veya mızraksı. Meyve yumurtamsı, turuncu-kırmızı renkli. Ülkemizde geniş bir yayılış alanına sahip olan bu alt tür, mayıs-ağustos ayında çiçeklenir. Yetişme ortamı olarak ise 1050-3200 m'ler arasındaki kireç taşlı kayalıkları ve yarıklarını, meşe çalııklarını, karaçam ormanlarını, stebi ve yol kenarlarını tercih eder. ÇBFCB. (Fig. 66)

\section{Familya: Urticaceae (Isırgangiller)}

\section{Parieteria judaica L. (Duvarfesleğeni)}

Çok dallı, (12-)20-50 cm boyunda çok yıllık otsu bitkiler. Yapraklar yumurtamsıdan dar eliptiğe kadar değişen şekillerde. Erkek ve hermafrodit çiçekler benzer. Dişi çiçekler dar mızraksı. Nisanağustos ayında çiçeklenen bu tür, yetişme ortamı olarak deniz seviyesinden 2000 m’ye kadar olan yüksekliklerdeki kireç taşlı kayalıkları, mağara ağızlarını ve duvarları tercih eder. ÇBFCB. 
Familya: Verbenaceae (Mineçiçeğigiller)

Verbena officinalis $L$. var. officinalis (Mineçiçeği)

30-100 cm boyunda, çok yıllık otsu bitkiler. Orta yapraklar mızraksı-mızraksı-dikdörtgenimsi. Kaliks 2-2.5 mm boyunda. Korolla silindir şeklinde, soluk leylak, boğaz kısmı sarımsı. Fındıksı meyveler 1.75-2 mm. Ülkemizde oldukça geniş bir yayılış alanına sahip olan bu tür, haziranağustos ayında çiçeklenir. Yetişme ortamı olarak ise deniz seviyesinden 1800 m'ye kadar olan yüksekliklerdeki kayalık yamaçları, kuru nehir yataklarını, duvarları, kum tepelerini, çalılıkları ve ormanlık alanları tercih eder. ÇBFCB.

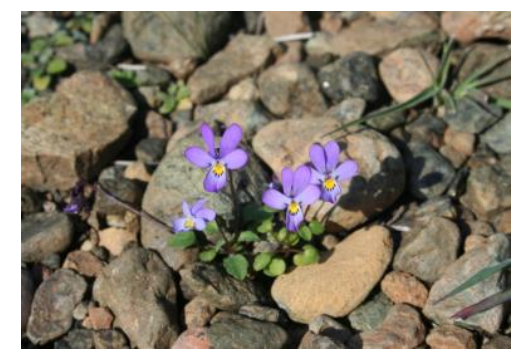

Fig. 67. Viola heldreichiana

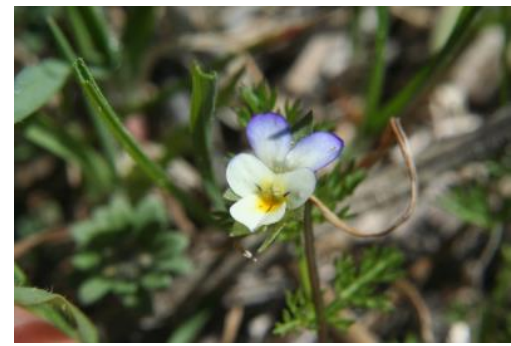

Fig. 68. Viola kitaibeliana

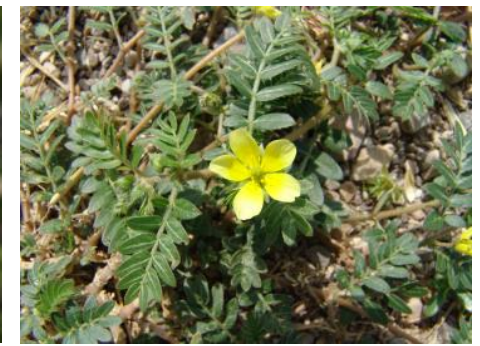

Fig. 69. Tribulus terrestris

Familya: Violaceae (Menekşegiller)

\section{Viola heldreichiana Boiss. (Gök menekşe) (Türkiye endemiği)}

3-12 cm boyunda, bir yıllık otsu bitkiler. Taban yaprakları dairesel, geri kalan yapraklar ise dikdörtgenimsi-kaşıksı. Pedunkul çiçeğin hemen altında iki brakteollü. Sepaller mızraksı. Çiçekler leylak-mavi renkli. Meyve kapsül. Ülkemize özgü olan bu tür, nisan-haziran aylarında çiçeklenir. Yetişme ortamı olarak ise deniz seviyesinden 1500 m’ye kadar olan yüksekliklerdeki kaya yarıklarını, taşıı alanları ve yamaçları tercih eder. D. Akd. El. (Fig. 67)

\section{Viola kitaibeliana Roem. \& Schult. (Yabani menekşe)}

3-12 cm boyunda, bir yıllık otsu bitkiler. Taban yaprakları dairesel, geri kalan yapraklar ise dikdörtgenimsi-kaşıksı. Pedunkul çiçeğin hemen altında iki brakteollü. Sepaller mızraksı. Çiçekler kremsi-beyazdan sarıya kadar değişen renklerde, merkezde sarı renkli. Meyve kapsül. Yetişme ortamı olarak ise deniz seviyesinden 1500 m’ye kadar olan yüksekliklerdeki, taşlı yamaçları ve makilikleri tercih eden bu menekşe türü, mart-temmuz aylarında çiçeklenir. ÇBFCB. (Fig. 68)

\section{Familya: Vitaceae (Asmagiller)}

\section{Ampelopsis orientalis (Lam.) Planch.}

Sürünücü veya tırmanıcı bitkiler. Yapraklar 1-2 ternat veya pinnat parçalı; yaprakçıklar dişli kenarlı, ve çıplak. Çiçekler 4 parçalı ve yeşil renkli. Üzümsü meyve olgun halde mavi-siyah renkli. Haziran-ağustos aylarında çiçeklenen bu tür, ülkemizde Akdeniz Bölgesinde yayılış göstermekte olup, 50-1800 m'ler arasındaki kayalık kireç taşlı yamaçlarda ve yaprak döken ormanlardaki kayalık yerlerde yetişmektedir. D. Akd. El.

\section{Familya: Zygophyllaceae (Çobançökertengiller)}

\section{Tribulus terrestris L. (Çobançökerten)}

Yatık gövdeli, 15-80 cm boyunda, bir yıllık otsu bitkiler. Yapraklar pinnat parçalı; yaprakçıklar yumurtamsı veya dikdörtgenimsi. Sepaller yumurtamsı. Petaller sarı renkli, 4-5 mm boyunda. Şizokarp meyve sert ve dikenli. Haziran-eylül aylarında çiçeklenen bu tür, 1200 m'ye kadar olan yüksekliklerdeki açık ve kumlu alanlarda ve tarlalarda yetişir. D. Akd. El. (Fig. 69) 


\section{Sınıf: Liliopsida (Monokotiller)}

\section{Familya: Amaryllidaceae (Nergisgiller)}

\section{Allium hirtovaginatum Kunth (Kıllı soğan)}

Dar yumurtamsı soğanlara sahip çok yıllık bitkiler. Gövde 10-30 cm boyunda. Yapraklar 3-5 adet, ipliksi. Şemsiye çiçek durumu dik sütunsu kümeli, birkaç çiçekli. Pediseller farklı uzunluklarda. Periyant segmentleri beyazımsı, kahverengi-beyaz, pembe, mor veya morumsu-menekşe renkli. Kapsül meyve yaklaşık $4 \mathrm{~mm}$. Bu tür, mayıs-ağustos aylarında çiçeklenir. Yetişme ortamı olarak ise deniz seviyesinden 2200 m'ye kadar olan yüksekliklerdeki karaçam ormanlarını, meşelik alanları, friganayı, alpinik alanları, stebi, kayalık yerleri ve serpantin alanları tercih eder. Akd. El.

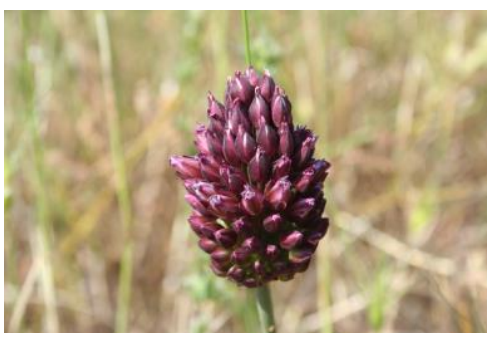

Fig. 70. Allium junceum subsp. tridentatum

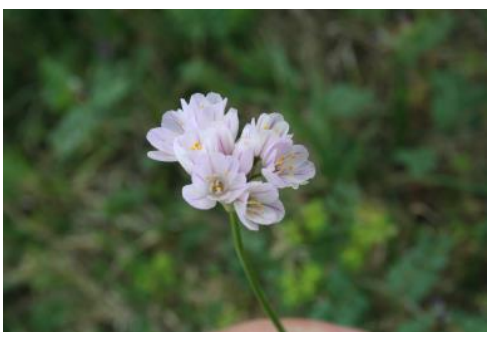

Fig. 71. Allium roseum subsp. roseum

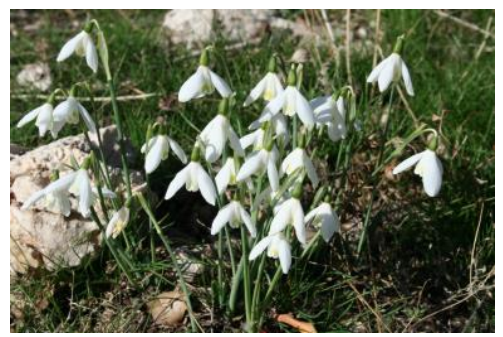

Fig. 72. Galanthus peshmenii

Allium junceum Sm. subsp. tridentatum Kollmann, Özhatay \& Koyuncu (Dişi körmen) (Türkiye endemiği)

Yumurtamsı soğanlara sahip çok yıllık bitkiler. Gövde 8-60 cm boyunda. Yapraklar 3-5 adet, ipliksi. Şemsiye çiçek durumu yumurtamsı-küresel. Pediseller farklı uzunluklarda. Periyant segmentleri bordo, mor veya menekşe renkli. Kapsül meyve yarı küresel, $4 \mathrm{~mm}$. Antalya ve Mersin illerine özgü olan bu alt tür, mayıs ve haziran aylarında çiçeklenir ve yetişme ortamı olarak 5-10 m'ler arasındaki yol kenarlarını, deniz kenarını ve ökaliptus ağaçlarının bulunduğu yerleri tercih eder. D. Akd. El. (Fig. 70)

\section{Allium roseum L. subsp. roseum (Gül soğanı)}

Çok yıllık soğanlı bitkiler. Soğanlar yumurtamsı veya yarı küresel. Gövde 10-65 cm boyunda. Yapraklar 2-4 adet, geniş̧̧e şeritsi. Şemsiye çiçek durumu ayrı küresel veya dik sütunsu kümeli. Periyant segmentleri pembe, nadiren beyaz renkli. Kapsül meyve $4 \mathrm{~mm}$. Nisan ve mayıs aylarında çiçeklenen bu gül soğan alt türü yetişme ortamı olarak deniz seviyesinden 2000 m'ye kadar olan yüksekliklerdeki makilikleri, kayalık yamaçları, çam ve göknar altlarını ve kültür alanlarını tercih eder. Akd. El. (Fig. 71)

\section{Galanthus peshmenii A. P. Davis \& C. D. Brickell (Peşmen kardeleni)}

20 cm'ye kadar boylanabilen çok yıllık soğanlı bitkiler. Yapraklar şeritsi. Çiçekler beyaz renkli. Meyve genişçe elipsiodden küresele kadar değişen kapsül. Bu kardelen türü, ekim-kasım (-aralık) aylarında çiçeklenmekte olup, yetişme ortamı olarak ise 5-700 m'ler arasındaki maki ve kızılçam ormanı altındaki kireçtaşı ihtiva eden kayalık alanları tercih eder. Akd. El. (Fig. 72)

Familya: Asparagaceae (Kuşkonmazgiller)

\section{Muscari parviflorum Desf. (Güz müşkürümü)}

Çok yıllık soğanlı bitkiler. Yapraklar 3-5 adet, darca şeritsi. Çiçekler seyrek; verimli çiçeklerin tüp kısmı açık maviden gök mavisine kadar değişen renklerde, lopları ise açık mavi veya beyaz renkli. Kapsül meyve 5-7 mm boyunda. Ağustos-kasım ayları arasında çiçeklenen bu tür, yetişme ortamı olarak deniz seviyesinden 900 m’ye kadar olan yüksekliklerdeki taşlı makilikleri, kireçtaşlı kayalık 
yamaçları ve zeytinlikleri tercih eder. Akd. El. (Fig. 73)

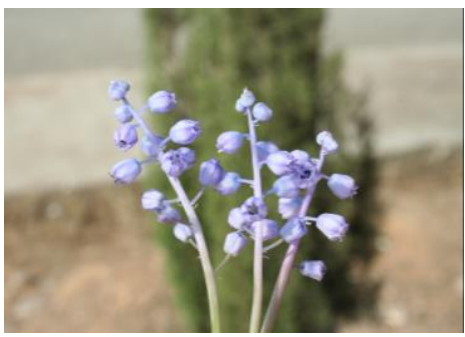

Fig. 73. Muscari parviflorum

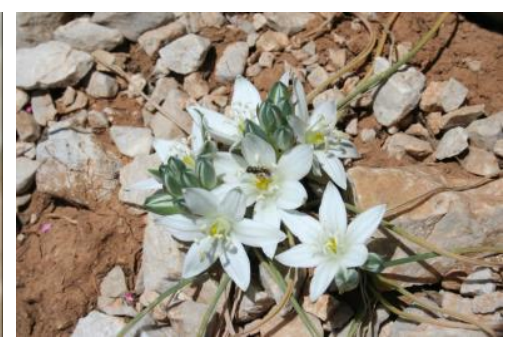

Fig. 74. Ornithogalum alpigenum

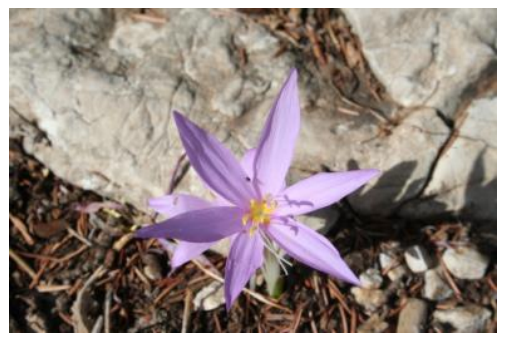

Fig. 75. Colchicum decaisnei

Ornithogalum alpigenum Stapf (Akyıldız) (Türkiye endemiği)

Soğanlı çok yıllık bitkiler. Çiçek kümesi gövdesi 7-12 cm boyunda. Yapraklar 3-7 adet, şeritsiipliksi. Periyant segmentleri beyaz renkli. Kapsül meyve kanatsız. Ülkemize özgü olan bu tür, yetişme ortamı olarak deniz seviyesinden 2300 m'ye kadar olan yüksekliklerdeki tepelikleri, kayalık yamaçları, stebi ve ormanları tercih eder. Çiçeklenme zamanı ise nisan-temmuz aylarıdır. D. Akd. El. (Fig. 74)

\section{Ornithogalum oligophyllum E. D. Clarke (Kurtsoğanı)}

Çok yıllık soğanlı bitkiler. Çiçek kümesi gövdesi 4-15 cm boyunda. Yapraklar 2-3 veya çok sayıda, şeritsi. Periyant segmentleri beyaz renkli. Kapsül meyve kanatsız. Çiçeklenme zamanı nisantemmuz aylarında olan bu tür, yetişme ortamı olarak kayalık yamaçlar ve kar açıkıklarını tercih eder. ÇBFCB.

\section{Familya: Colchicaceae (Acıçiğdemgiller)}

Colchicum decaisnei Boiss. (Göç kovan)

Çok yıllık kormlu bitkiler. Korm dar yumurtamsıdan yarı küresele kadar değişen şekillerde. Yapraklar 3-5 (-6) adet, şeritsi-mızraksıdan, mızraksıya veya darca yumurtamsıya kadar değişen şekillerde. Periyant segmentleri morumsu-pembe ya da beyazdan leylağa kadar değişen renklerde. Kapsül meyve dikdörtgenimsiden eliptiğe kadar değişen şekillerde. Ağustos-kasım aylarında çiçeklenen bu tür, yetişme ortamı olarak deniz seviyesinden 2000 m’ler arasındaki orman ve maki açıklıklarını, kayalık-taşlık alanları tercih eder. Ülkemiz dışında batı Suriye, Lübnan ve Kuzey Israil'de yayılış gösterir. D. Akd. El. (Fig. 75)

\section{Familya: Cyperaceae (Hasırotugiller)}

\section{Cyperus capitatus Vand. (Şehvetotu)}

Sağlam yapılı çok yıllık rizomlu bitkiler. Gövde $10-80 \mathrm{~cm}$ boyunda. Yapraklar yarı tabanda, kırık. Brakteler 3-6 adet, çiçek durumundan uzun. Çiçek durumu yoğun, küresel veya yarı dairesel. Başakçıklar 8-15 mm boyunda. Kavuz genişçe mızraksıdan yumurtamsıya kadar değişen şekillerde. Haziran-ağustos aylarında çiçeklenen bu tür, deniz kenarındaki kumullarda yetişir. ÇBFCB.

\section{Familya: Iridaceae (Süsengiller)}

\section{Crocus cancellatus Herb. subsp. Iycius B. Mathew (Garip çiğdem) (Türkiye endemiği)}

Çok yıllık kormlu bitkiler. Yapraklar 3-7 adet, çiçeklenme döneminde mevcut değil. Periyantın boğazı sarı renkli, segmentler beyaz renkli. Kapsül meyve silindirikten elipsoide kadar değişen şekillerde. Ülkemize özgü olan bu çiğdem sadece Antalya ve Muğla illerinde yetişmektedir. Bu alt tür, eylül ve kasım aylarında çiçeklenmekte olup, yetişme ortamı olarak 50-2400 m'ler arasındaki kayalık yamaçları, seyrek ormanlıkları ve makilikleri tercih eder. D. Akd. El. (Fig. 76) 


\section{Crocus danfordiae Maw subsp. danfordiae (İnce çiğdem) (Türkiye endemiği)}

Çok yıllık kormlu bitkiler. Yapraklar 3-7 adet, çiçeklenme döneminde mevcut. Periyantın boğazı sarı veya beyaz renkli, segmentler soluk sarı, soluk leylak-mavi veya beyaz renkli. Stilus 3 parçalı, sarı ya da turuncu renkli. Kapsül meyve silindirikten elipsoide kadar değişen şekillerde. 1879 yılında Adana'dan toplanarak 1881 yılında Maw tarafından bilim dünyasına tanıtılan bu alt tür ülkemize özgüdür. Yetişme ortamı olarak 950-2000 m’ler arasındaki açık tepelikleri, çalılıkları ve çam altlarını tercih eder. Çiçeklenme zamanı ise şubat ve mart (-nisan) aylarıdır. ÇBFCB. (Fig. 77)

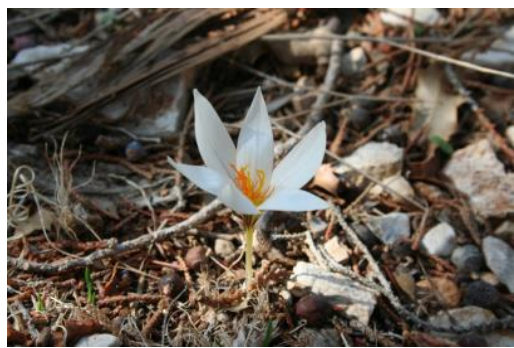

Fig. 76. Crocus cancellatus subsp. lycius

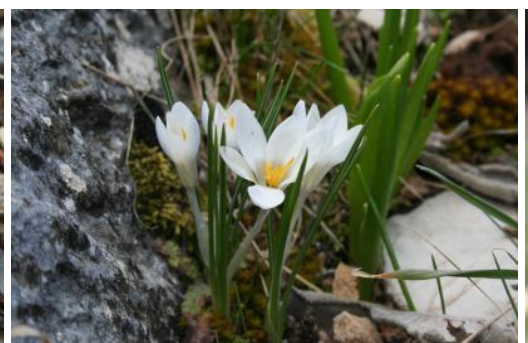

Fig. 77. Crocus danfordiae subsp. danfordiae

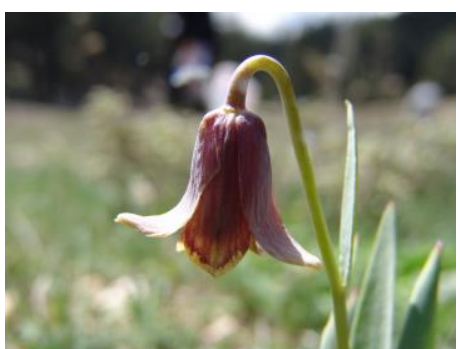

Fig. 78. Fritillaria pinardii

Familya: Juncaceae (Kofagiller)

50-100 cm boyunda rizomlu bitkiler. Yapraklar uzun ve dar, bitkinin geri kalanına benzer. Çiçek durumu çok çiçekli. Periyant segmentleri koyu kahve renkli, dikdörtgenimsi. Kapsül meyve küreselden yumurtamsı-üçgenimsiye kadar değişir, koyu kahve renkli. Deniz kumullarında ve tuzlu göllerin kıyılarında yetişen bu tür, nisan-haziran aylarında çiçeklenir. Akd. El.

Familya: Liliaceae (Zambakgiller)

\section{Fritillaria pinardii Boiss. (Mahçup lale)}

Soğanlı çok yıllık bitkiler. Gövde 6-20 cm boyunda. Yapraklar altta 3-8 adet, genişçe veya darca mızraksı. Periyant segmentleri dış kısımda morumsudan grimsiye kadar değişen renklerde iç kısımda ise sarımsı-turuncu veya yeşilimsi renkli. Kapsül meyve kanatsız. Ülkemizde oldukça geniş bir yayılış alanına sahip olan bu tür, nisan-haziran aylarında çiçeklenir. Yetişme ortamı ise 1000-2500 m'ler arasındaki kayalık tepelikleri, stebi ve eriyen karlık alanları tercih eder. Ir.-Tur. El.

(Fig. 78)

\section{Familya: Orchidaceae (Salepgiller)}

\section{Cephalanthera kurdica Bornm. ex Kranzlin (Kurtkuşçuğu)}

Rizomlu, 10-50 cm boyunda çok yıllık bitkiler. Yapraklar yumurtamsımızraksı. Başak çiçek durumu yoğun. Çiçekler parlak gül renkli, nadiren beyaz renkli. Sepaller hafif yayılıcı. Petaller kısa. Mahmuz konik. 1500 m'ye kadar olan yüksekliklerdeki makilikleri, meşe ve çam ormanları, kalkerli taşlık alanları tercih eden bu tür, nisan ve mayıs(haziran) ayında çiçeklenir. Ir.-Tur. El. (Fig. 79)

Ophrys lyciensis Paulus, Gügel, D. Rückbr. \& U. Rückbr. (Çalı salebi) Narin yapılı, 15-50 cm boyunda, toprakaltı yumrulu çok yıllık bitkiler. Yapraklar 6-9 adet, eliptikten mızraksıya kadar değişen şekillerde, 3-

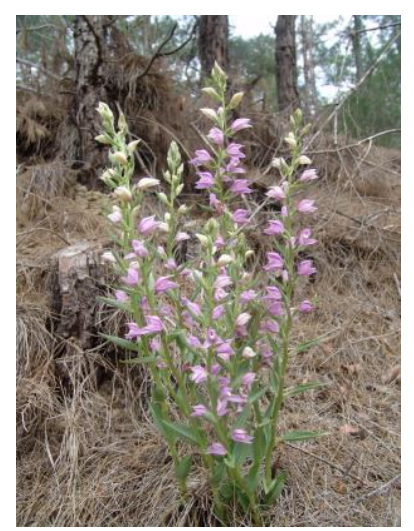

Fig. 79. Cephalanthera kurdica $12.5 \mathrm{~cm}$ boyunda. Çiçek durumu seyrek, 4-12 çiçekli. Sepaller yumurtamsıdan dikdörtgenimsiye kadar değişen şekillerde, beyazdan menekşemsi-açık morumsuya 
kadar değişen renklerde. Petaller üçgensi, beyazımsı-pembe kadfemsi yoğun tüylü. Labellum tam kenarlı. Nisan ve mayıs aylarında çiçeklenen bu tür, yetişme ortamı olarak deniz seviyesinden 850 m’ye kadar olan ormanlık ve makilik alanları, friganayı ve kireç taşlı yamaçları tercih eder. Akd. El. (Fig. 80)

\section{Ophrys holoserica (Burm. f.) Greuter subsp. heterochila Renz \& Taubenheim (Deşdiye salebi)} 8-30 cm boyunda, toprakaltı yumrulu çok yıllık bitkiler. Yapraklar 4-6 adet. Çiçekler 3-8 adet. Sepaller yumurtamsıdan dikdörtgenimsiye kadar değişen şekillerde, geriye kıvrık, beyazdan yeşilimsi veya menekşemsi-açık morumsuya kadar değişen renklerde. Petaller üçgensi. Labellum ters yumurtamsı veya yumurtamsı, 7-13 mm boyunda. Mart ve nisan aylarında çiçeklenen bu bitki, yetişme ortamı olarak deniz seviyesinden 770 m'ye kadar olan yüksekliklerdeki ormanlık ve makilik alanları, çayırıkları, friganayı ve kireç taşlı yamaçları tercih eder. Akd. El.

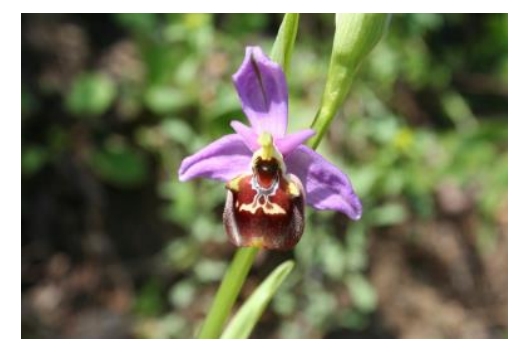

Fig. 80. Ophrys lyciensis

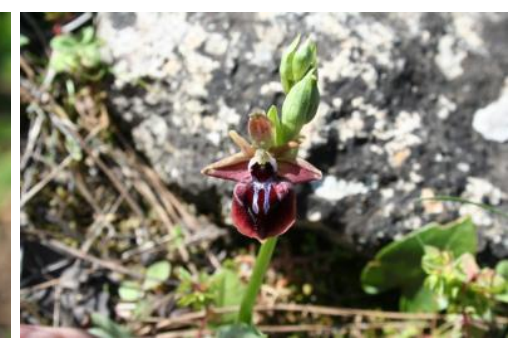

Fig. 81. Ophrys mammosa subsp.

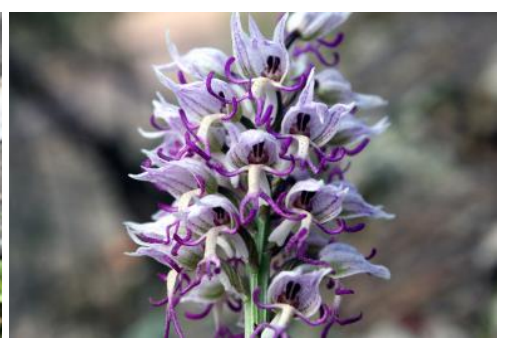

Fig. 82. Orchis simia

\section{Ophrys mammosa Desf. subsp. mammosa (Kedikulağı)}

20-50 cm boyunda, toprakaltı yumrulu çok yıllık bitkiler. Yapraklar 3-6 adet, dikdörtgenimsiyumurtamsı. Çiçek durumu 2-10 çiçekli; çiçekler iri. Sepaller yeşil renkli, sırtta dik ve yanlara doğru eğilici. Petallar sarımsı veya kahverengi-yeşil. Labellum yuvarlak veya yumurtamsı, uçta hafif çıkıntıl; spekulum H şeklinde, soluk mavimsi ve tüysüz. Mart-nisan(-mayıs) aylarında çiçeklenen bu alt tür, ülkemizin kıyı kesimlerindeki 1250 m’ye kadar olan yamaçlarda, çam ormanlarında, frigana'da makiliklerde ve meşeliklerde yetişir. Akd. El. (Fig. 81)

\section{Orchis simia Lam. (Salep Püskülü)}

20-50 cm boyunda, yumrulu çok yıllık bitkiler. Yapraklar tabanda 2-5 adet, Dikdörtgenimsi den dikdörtgenimsi-mızraksıya kadar değişen şekillerde. Başak çiçek durumu yumurtamsıdan konike kadar değişir. Sepaller uzun akuminat. Labellum 15-20 mm, merkezde beyazımsı gül renkli, küçük morumsu papillalı ve derin şeritsi loplu; tüm loplar uç kııımda koyu mor renkli. Mahmuz silindirik. Nisan ve mayıs aylarında çiçeklenen bu orkide türü, yetişme ortamı olarak deniz seviyesinden 1650 m'ye kadar olan yüksekliklerdeki kalkerli toprakları, çimenli tepelikleri ve çalılıkları tercih eder. Akd. El. (Fig. 82)

\section{Serapias bergonii E. G. Camus (İnce sağırkulağı)}

Yumrulu, 10-40(-50) cm boyunda çok yıllık bitkiler. Yapraklar mızraksı. Başak çiçek durumu 20 cm'ye kadar uzar. Brakteler mıraksı. Epikil koyu mor, geniş veya dar mızraksı, dikdörtgenimsimızraksı veya dar kalpsi. Hipokil geniş. Bu tür, ülkemizde Marmara, Ege ve Akdeniz Bölgelerinde ülkemiz dışında ise Yunanistan, Ege adaları ve Kıbrıs'ta yayılış göstermektedir. 50-1000 m’ler arasındaki yüksekliklerdeki kuru veya nemli çimenliklerde, frigana'da, makiliklerde ve yol kenarlarında yetişir. Çiçeklenme zamanı ise mart-mayıs aylarıdır. Akd. El. (Fig. 83)

Familya: Poaceae (Buğdaygiller) 
Bromus intermedius Guss. (Damiyeotu)

Dik veya eğik tırmanışı, $10-75 \mathrm{~cm}$ boyunda bir yıllık otsu bitkiler. Yaprak ayası 5-10 cm boyunda, seyrek tüylü. Başakçıklar 10-20 mm boyunda, mızraksı. Kavuzlar mızraksı. Dış kavuz dikdörtgenimsi-mızraksı. Meyve karyopsis. Nisan-temmuz aylarında çiçeklenen bu bitki, deniz seviyesinden 1750 m'ye kadar olan yüksekliklerdeki tarlalarda, frigana açıklıklarında, tarla kenarlarında, nemli yerlerde ve kumlu yerlerde yetişir. ÇBFCB.

\section{Hyparrhenia hirta (L.) Stapf (Damsazı)}

Sağlam yapılı çok yıllık bitkiler. Gövde 90 cm'ye kadar çıkar. Yaprak ayası darca şeritsiden ipliksiye kadar değişen şekillerde. Başakçıklar 4$20 \mathrm{~cm}$ boyunda, bir iki çiçekli, yeşilimsi- menekşe renkli. Karyopsis meyve tersmızraksı. Nisan-eylül aylarında çiçeklenen bu tür, yetişme

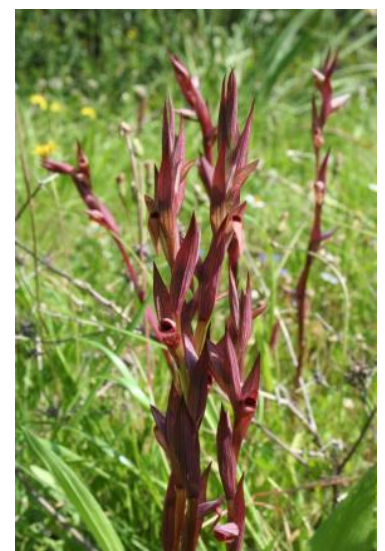

Fig. 83. Serapias bergonii ortamı olarak deniz seviyesinden 1330 m’ye kadar olan yüksekliklerdeki taşlık tepeleri, friganayı, kumul otluk alanları tercih eder. ÇBFCB.

\section{Melica minuta L. (Yer inciotu)}

Narin yapılı, 20-50 cm boyunda çok yıllık otsu bitkiler. Yaprak ayası şeritsi. Bileşik salkım çiçek durumu seyrek, 3-12 cm boyunda. Başakçıklar 7-9 mm boyunda. Kavuz membranımsı. Karyopsis meyve yumurtamsı-dikdörtgenimsi. Ülkemizde Ege ve Akdeniz Bölgeleri'nde yayılış gösteren bu tür, nisan ve mayıs aylarında çiçeklenir. Yetişme ortamı olarak ise deniz seviyesinden 1900 m'ye kadar olan yüksekliklerdeki makilikleri, friganayı kireç taşlı yamaçları tercih eder. ÇBFCB.

\section{Familya: Xanthorrhoeaceae (Çirişgiller)}

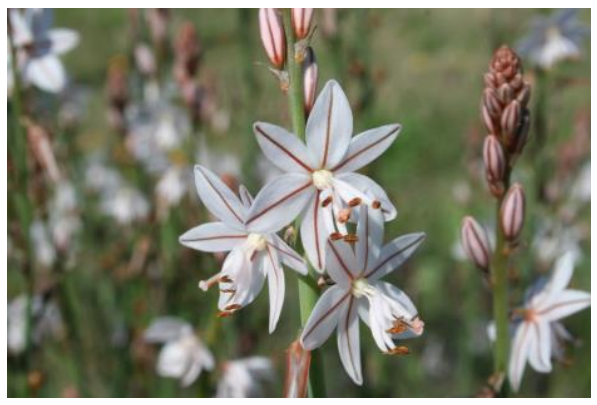

Fig. 84. Asphodelus fistulosus subsp. fistulosus

\section{Asphodelus fistulosus L. subsp. fistulosus (Hıdırellezkamçısı)}

Bir veya kısa ömürlü çok yıllık otsu bitkiler. Yapraklar tabanda, şeritsi. Periyant segmentleri beyaz veya soluk pembe ve kahverengimsi orta damarlı. Kapsül meyve hemen hemen küresel. Martmayıs aylarında çiçeklenen bu alt tür yetişme ortamı olarak deniz seviyesinden 900 m'ye kadar olan yüksekliklerdeki kayalık yerleri ve tarlaları tercih eder. Akd. El. (Fig. 84)

\section{Sonuç ve Tartışma}

Phaselis Antik Kenti'nde 2012-2016 yılları arasında gerçekleştirilen proje kapsamında, 2016 yılında yapılan arazi çalışması sonucunda 63 familya'ya ait 157 cins ve toplam 195 takson tespit edilmiştir (ayrıca bk. Arslan \& Tüner-Önen 2015). 2016 yılında tespit edilen 195 taksonun 37 tanesi endemik olup (\% 18,9), bunların 4 tanesi Olimpos-Beydağları Milli Parkı endemiği, 1 tanesi Antalya endemiği ve 32 tanesi de Türkiye endemiğidir. Çalışma alanından 2016 yılında tespit edilen 195 taksonun fitocoğrafik bölgelere dağılımı ise şu şekildedir; 80 tanesi Akdeniz Fitocoğrafik Bölgesi elementi, 6 tanesi İran-Turan Fitocoğrafik Bölgesi elementi, 4 tanesi AvrupaSibirya Fitocoğrafik Bölgesi elementi ve 105 tanesi ise Çok Bölgeli veya Fitocoğrafik Bölgesi bilinmeyen. 2016 yılında alanda tespit edilen 195 taksonun 3 tanesinin Pteridophyta (Eğreltiler) şubesine, 192 takson ise Magnoliophyta (Tohumlu bitkiler) şubesine ait olduğu görülmüştür. Pinophytina (Açık tohumlular) alt şubesinde 1, Magnoliophytina (Kapalı tohumlular) alt şubesinde ise 191 takson yer almaktadır. Magnoliophytina (Kapalı tohumlular) alt şubesinde yer 
alan 191 taksonun 168 tanesi Magnoliopsida (Dikotiller) sınıfına, 23 tanesi ise Liliopsida (Monokotiller) sınıfına aittir.

Proje sonunda 84 familyaya ait 360 cins ve 440 tür, 131 alt tür, 60 varyete olmak üzere toplam 631 takson tespit edilmiştir. Tespit edilen bu 631 taksonun 99 tanesi endemiktir (\% 15,6). Bu endemik taksonların 15 tanesi Olimpos-Beydağları Milli Parkı endemiği, 19 tanesi Antalya endemiği ve 65 tanesi ise Türkiye endemiğidir. 631 taksonun 8 tanesinin Pteridophyta (Eğreltiler) şubesine, 623 takson ise Magnoliophyta (Tohumlu bitkiler) şubesine ait olduğu görülmüştür. Pinophytina (Açık tohumlular) alt şubesinde 8, Magnoliophytina (Kapalı tohumlular) alt şubesinde ise 615 takson yer almaktadır. Magnoliophytina (Kapalı tohumlular) alt şubesinde yer alan 615 taksonun 523 tanesi Magnoliopsida (Dikotiller) sınıfına, 92 tanesi ise Liliopsida (Monokotiller) sınıfına aittir.

Çalışma sonunda tespiti yapılan taksonların 304 tanesi Akdeniz Fitocoğrafik Bölgesi elementi, 18 tanesi İran-Turan Fitocoğrafik Bölgesi elementi, 15 tanesi Avrupa-Sibirya Fitocoğrafik Bölgesi elementi ve 294 tanesinin ise Çok Bölgeli veya Fitocoğrafik Bölgesi bilinmeyen olduğu görülmüştür. Bu çalışma sonucunda Akdeniz Fitocoğrafik Bölgesi elementlerinin 304 takson (\% 48,1) ile ilk sırada yer aldığı görülmekte olup, bunun nedenini araştırma alanın tümüyle Akdeniz Fitocoğrafik Bölgesi içinde yer alması ile açıklayabiliriz. Çalışma alanında İran-Turan Fitocoğrafik Bölgesi elementleri 18 takson (\% 2,85) ve Avrupa-Sibirya Fitocoğrafik Bölgesi elementleri 15 takson (\% $2,37)$ ile alanda belirgin şekilde az sayıda yer aldığı görülmektedir. Bunun nedenini ise bu iki fitocoğrafik bölgenin karakterlerini yansıtan habitatların alanda sınırlı olması ile açıklayabiliriz. Alanda Çok Bölgeli veya Fitocoğrafik Bölgesi bilinmeyen taksonların sayısı ise 294 (\% 46,5)'dür.

Çalışma alanında takson sayısı açısından en zengin ilk 5 familya ve takson sayıları şu şekildedir; Asteraceae 74, Lamiaceae 69, Fabaceae 51, Caryophyllaceae 30 ve Brassicaceae 24.

\section{BİBLIYOGRAFYA}

Göktürk, R. S. 2015. "Phaselis Antik Kenti Florası I". Phaselis I (2015) 81-131.

Göktürk, R. S. $2016 . \quad$ "Phaselis Antik Kenti Florası II". Phaselis II (2016) 57-101.

Arslan \& Tüner-Önen 2015 “Phaselis ve Teritoryumu Yüzey Araştırması 2015”. ANMED 14 (2016) 236-246. 